\title{
POICE EUCATIEENRENCE.
}

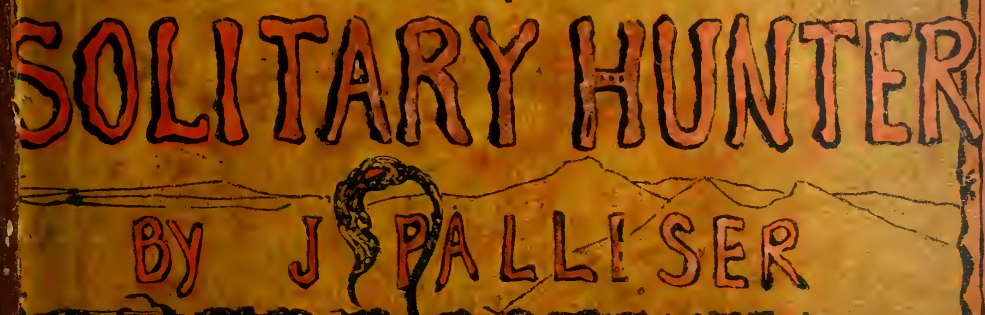

cin
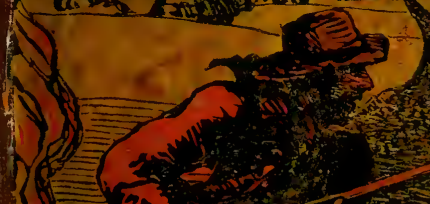

ses:

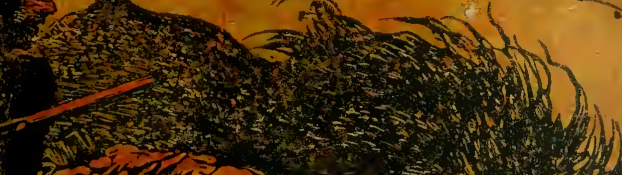

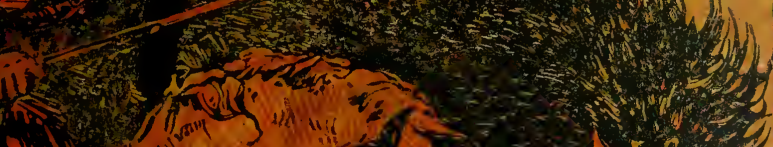

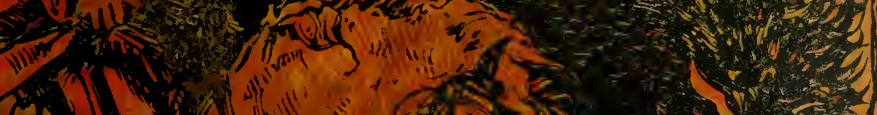

(1)

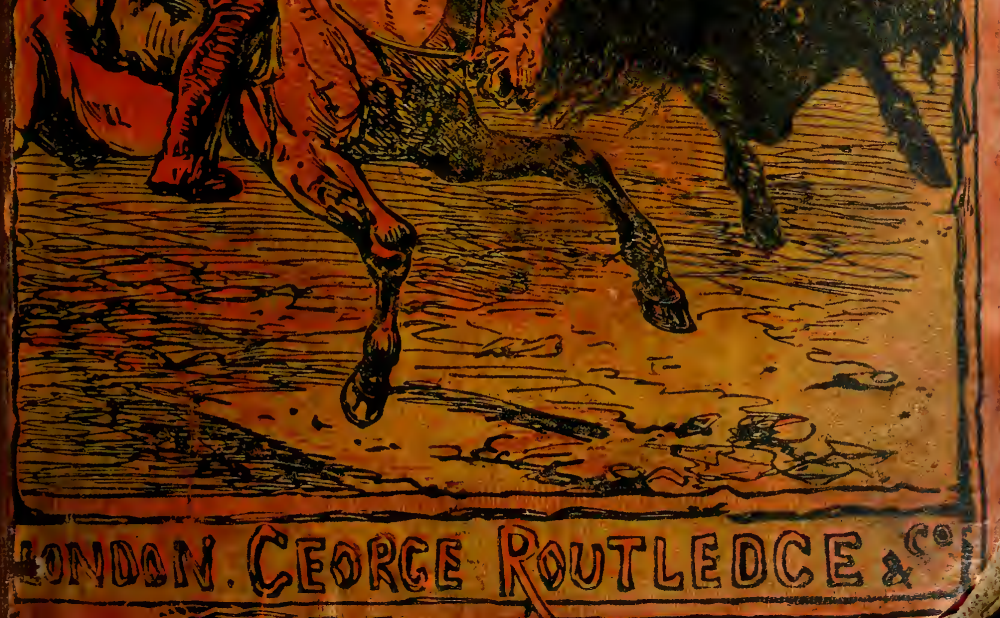




\section{UNIVERSITY OF PITTSBURGH}

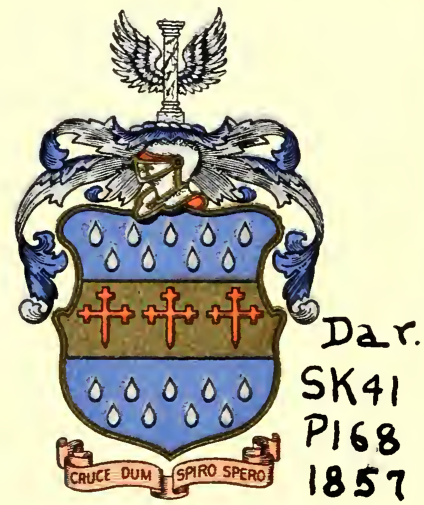

Darlington Memorial Library 





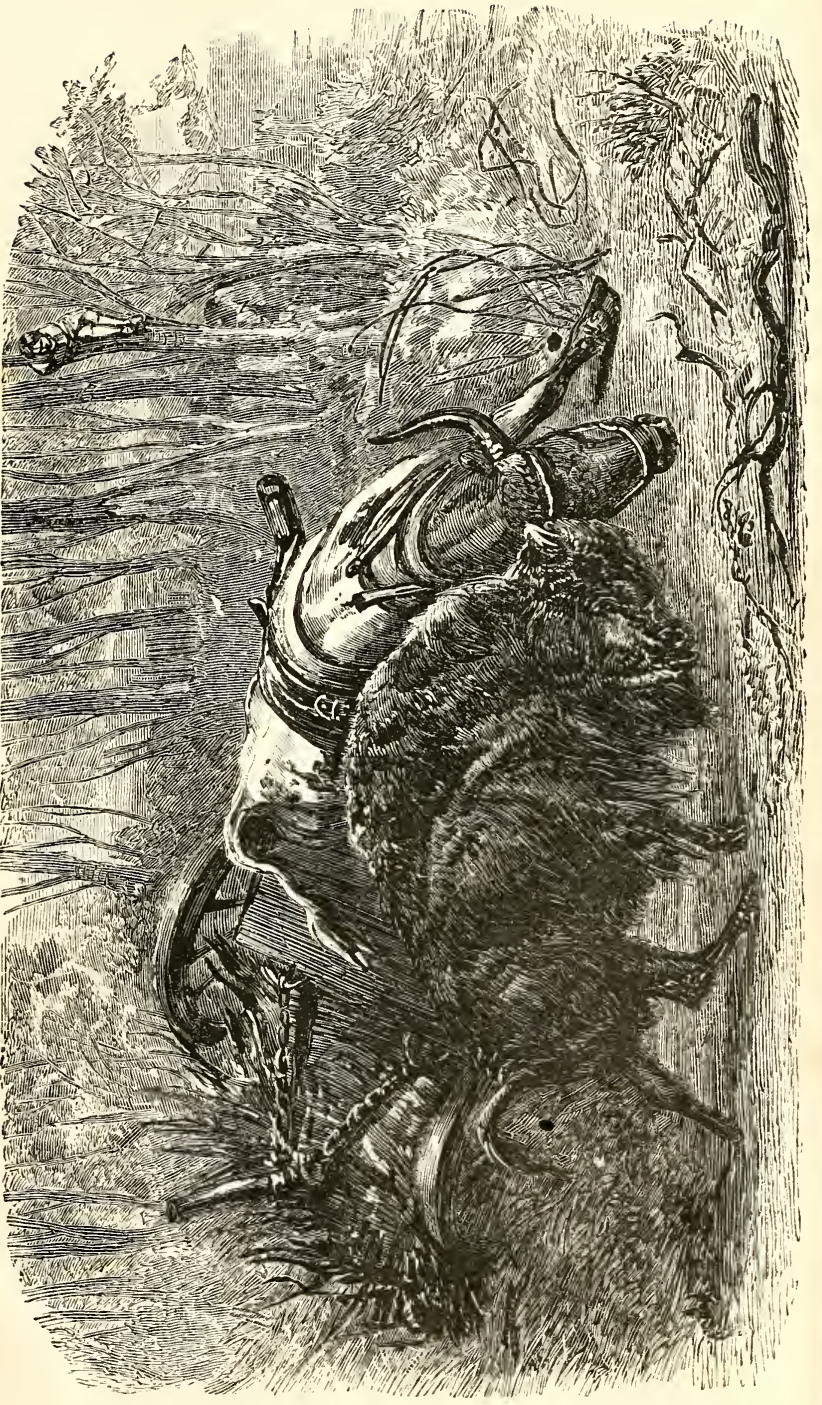


THE

\section{SOLITARY HUNTER; \\ OR,}

SPORTING ADVENTURES IN THE PRAIRIES.

BY

JOHN PALLISER, ESQ.

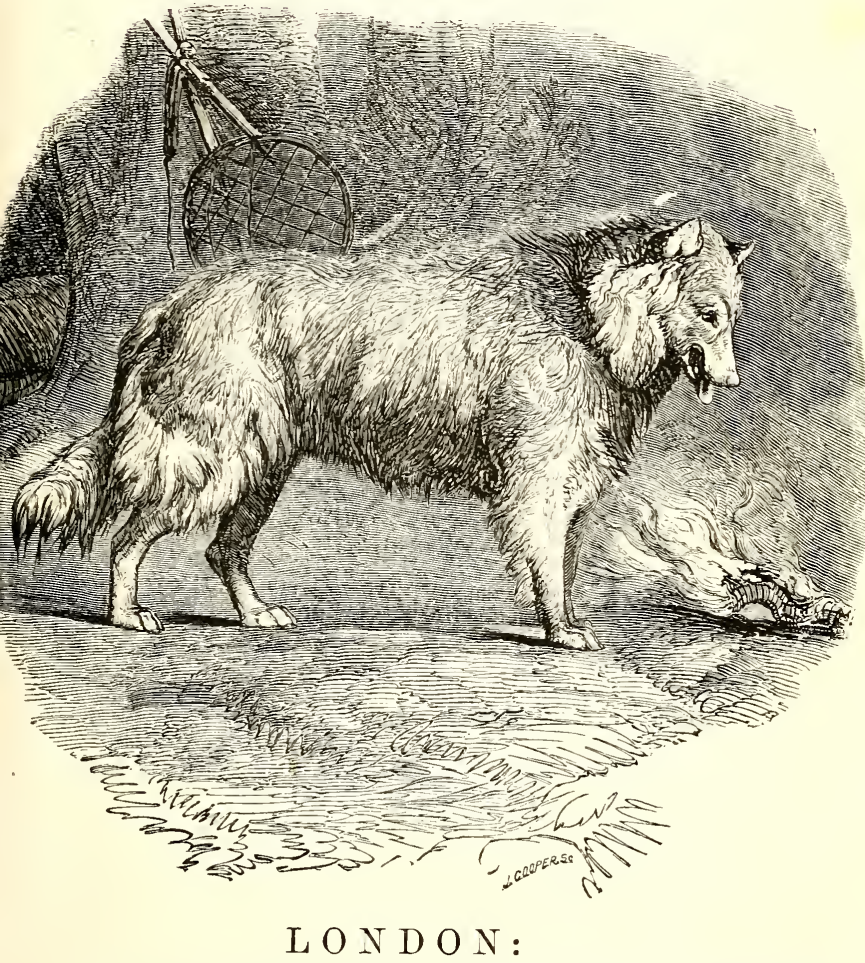

EORGE ROUTLEDGE \& CO., FARRINGDON STREET; AND 18, BEEKMAN STREET, NEW YORK. 




\section{MY BROTHER SPORTSMEN OF ENGLAND, IRELAND, AND SCOTLAND.}

\section{Dear Friends,}

I was induced, on my return from America, to collect the very scanty contents of an imperfect journal, which recorded, for the perusal of a few intimate friends, my experiences of adventure in the far West. These kind critics afterwards tempted me to enlarge the circle of my readers, by many assurances of the indulgence which a courteous public extends towards deficiencies of style and composition in a writer more accustomed to the use of the rille and hunting-knife than to that of the pen.

In this age of literature, when so many works of imagination are appearing every day, I should despair of such a mere matter-of-fact story finding any place in the attention or interests of the reading world, did I not firmly rely on your sympathies.

Without further apology, therefore, I will preface my story by an attempt to give you the benefit of what experience I have acquired in outfitting for distant nunting expeditions, in the hope that it may prove of use to such of you as may contemplate similar excursions; in helping you to provide yourselves with things which are really necessary, and also to avoid burthening 
yourselves with what is cumbersome, and comparatively useless.

Of guns, the most valuable and indispensable is the plain, smooth-bore, doubled-barrelled gun, about fourteen to twelve in the bore. Let it be made by a firstrate maker, one who himself superintends the manufacture of every portion of his guns; for, in a country where there are no gunsmiths to run to in case of an accident, the breaking of a trigger or a shear, or the failure of some screw of inferior metal or workmanship, may involve the most serious consequences. I, for my own part, as well as both my brothers, in our numerous hunting expeditions in America, India, and Ceylon, have always used the guns and rifles of Trulock and Son, of Dawson Street, Dublin, which, for accuracy, power, and trustworthiness, I have seldom suen equalled, and never excelled. Nothing gives the sportsman so much confidence in using the heavy charges required in elephant-shooting, as the knowledge that the barrels in his hands have been forged by a good maker.

I do not deny that good barrels may be made in Birmingham ; but I am convinced that there is nothing like the master's eye over a gun in every stage of its construction. For close and dangerous shooting I know nothing equal to the double-barrelled, smooth-bore gun. You can load it more rapidly, and handle it more quickly and dexterously, than any other, also at the same time sufficiently depend upon it for accuracy as far as sixty or seventy yards.

Next in importance I would suggest a single-barrelled 
two-grooved rifle, which I much prefer to the poly- or many-grooved, for the reasons that with the former you can use a larger charge of powder without danger of the bullet tripping ; you may fire a greater number of shots without fouling the barrel or losing in accuracy, and if you use fancy conical projectiles, you may do so with less chance of damage to your rifle.

Were I so circumstanced that I could take a third gun with me, it would be a double-barrelled, two-grooved rifle, whose execution at long range, though below that of the single rifle, is, of course, far more accurate than that of the smooth-bore : experience has, indeed, satisfied me that, for a very long shot, you never can count upon the same precision with a double as with a single barrel. Even supposing the barrels to be perfectly parallel (which is almost an impossibility), still the direction of recoil of each when fired is different, and has a different effect upon the flight of the bullet; so that barrels, which would throw almost exactly parallel when discharged from a vice, will slightly diverge from each other when fired from the shoulder. You must not infer from these remarks that I undervalue the double rifle. For deer-shooting, especially, it is invaluable; and often, when I have missed a deer with the first barrel, has the animal stood still at the report, as if from curiosity, and afforded me a second shot. I merely would not have you expect too much from it, or reckon that its accuracy of execution beyond one hundred and fifty yards is equal to that of a good single-barrel rifle. 
As to calibre, sportsmen of the Western are much at variance with those of the Eastern world, the former preferring the small bullet of thirty-two, forty, or even fifty, to the pound, while their East-Indian brethren are as strongly in favour of the large ball, running from sixteen to twelve, or even eight only to the pound. The reason of this discrepancy I fancy is this, that the difficulty of obtaining good powder is much greater in the West than in the East; for, the larger the ball, the greater the necessity for superior powder.** For my own part, I should be inclined to select a size carrying from twenty-four to sixteen to the pound.

In your choice of knives, do not be induced to encumber yourself with any thick-bladed, highlyilluminated cutlery of the German jäger fashion : they are very handsome to look at, when hung up over a chimney-piece, but very ineffective in the field, wearying and blistering the hands, and splintering against the bones of any large animal. The best knife for hunting purposes, in my opinion, is a good, plain, wooden-handled butcher-knife: let the handle be long, and the blade thin.

-In horses, your great object should be to combine the greatest hardiness with the highest courage. A thorough-

* By increasing your charge beyond a certain quantity you do not increase the force. No more powder will ignite than is suffcient to cover the bullet if it is placed on a table and powder poured gently over it until it is concealed. If you hear your ball strike the object fired at, it is a pretty sure indication of deficiency of force, either in the quantity or the quality of the powder. 
bred horse you can train to rush at anything: his being timid at first, or apt to shy, has nothing to do with any absence of courage. By patience and perseverance, you will teach him to charge any animal, not excepting a grisly bear; while a common, badly-bred brute will not even pursue a bison. Mules, for packing, are, in some respects, superior to horses; but they cannot support intense cold nearly so well. I strongly advise especial and constant attention to saddles. Go where you will, and all over the world, you will find nothing to equal the English saddle. Provide yourselves with them at any cost, and transport them at any inconvenience. When on the prairie, travel with a blanket saddle-cloth. You will find it a comfortable addition to your bed; but be careful before putting the saddle over it on the horse, that there is no crease in its folds; for a sore on your horse's back is a serious inconvenience to a long: journey. It is a good plan, before fastening the girths, to pass your forefinger under the saddle-cloth, and lift it slightly off the horse's withers.

For clothing, I think there is nothing like Scotch woollen stuffs; leather, after all, is but an inconvenient substitute for these; for though it has its advantages in point of wear, it is horribly uncomfortable in wet weather, and dries as hard and stiff as parchment.

Keep your gunpowder in air-tight packages; exposure to the atmosphere weakens it. Do not burthen yourselves uselessly by trying to forestall a thousand imaginary necessities. Beyond your guns and horses, with their several appurtenances, you will absolutely 
require nothing on the prairie but your knife, flint and steel, and pipe, an iron ladle for melting lead, a tin mug, and two iron kettles, one for cooking, the other for boiling coffee-with iron covers to them, which will respectively do for frying meat, and for roasting your coffee.

Before leaving the Settlements, provide yourselves with lead, tobacco, coffee, sugar, salt, needles, awls, strong thread, and shoemaker's wax, and also one or two dressed skins, for making and mending mocassins ; and with this equipment, you may pass from Independ. ence to the Pacific Ocean. 


\section{O N TENTS.}

\section{CHAPTER I.}

The Start.-Gen. Tom Thumb.-Halifax.-Astor House.-American Railways.-Philadelphia._Baltimore Beauties.-A Clinical Professor.-Mark Tapley's Eden.-The great Missouri.-Drinks.New Orleans.-Night Adventure.-Creole Ladies.-Col. White's Oratorio of "David."-Page 1.

\section{CHAPTER II.}

Arkansas forests.-Deer-shooting.-The Major's good shots.-FirePan-hunting.-Fine fat Bucks.-Still-hunting.-First night in the Woods.-Panther shot.-Black bait for an Alligator.-Assassination of a Bear.-Page 27.

\section{CHAPTER III.}

Mammoth Caves.-Stalactite Architecture.-Ancient America.Rambles in the Earth.-Mummy found.-Subterranean Ball. St. Louis Hunting Club.-A good run.-A fat Buck killed.Hospitable Hunters.-Kentucky talked down.-American Fus Company.-Page 48. 


\section{CHAPTER IV.}

Old Mr. Kipp.-Preparing for the Start.-Mormons.-Camping at Night.-Duck-shooting.-Gigantic Vegetation.-Prairie on Fire. -Fort Vermilion.-Scalp Dance.-A Dog Feast.-A Woman bought and saved.-Hint from a Bullet.-Fort Pierre.-Page 59.

\section{CHAPTER V.}

Clear A tmosphere.-See Buffalo.-Arrival at Fort Union.-Buffalo. bunting.-Winter sets in.-nuntıng Party.-Escape from a War Party.-A Race for Life or Death.-Wanton Cruelty of the Sioux.-A heroic old Bull.-Domestic Calves and Bison Bull.Page 75.

\section{CHAPTER VI.}

Tossed by a Buffalo.-Elk-shooting.-Wolves.-Spoil a Cannibal Feast.-Ishmah.-Hard up for Meat.-Owen Mackenzie's Post. -The Traders.-Page 100.

\section{CHAPTER VII.}

Giutton Feast.-My Indian Companion.-Hunting in Snow.-Roast Loin of Wolf.-Black-tail Deer.-Rapacious Beauties.-Another Journey.-A Long Shot.-Indian Voracity.-Larpenter's Post. -Start for the Minitarées.-Awful Night.-Peekay and the Bull.-Reach Fort Berthold.-Page 121.

\section{CHAPTER VIII.}

Mr. Chardon.-Boucharville.-Geese put their heads together.Ice breaks up.-A Cold Bath.-Arrive at the Fort.-Preparations. -An Afternoon's Hunt.-Elk shows Fight. - Shot at Sun-down. -Hard Work.-Page 143. 


\section{CHAPTER IX.}

Hunt on the Yellow Stone.-Grosse-Corne Hunting.-A Beautiful Camp.-Beaver.-Good Hunting Country.-Cat Fishing.-Skinboat Building.-Tailoring.-Crow Indians.-Descend the Iellow Stone. - Surprise a Crow Camp. - Return to Fort Union.Page 156.

\section{CHAPTER $X$.}

Dispose of the Meat.-Descend the Missouri.-A Tir-party.They decline the attack.-Obtain two more fullcwers.-Kili a young Bear.-The grisly Bear.-A breakfast of Marrow.-Nearly kill two eagles with a ball.-Chase and capture two Bison calves. -Return to Minitarée Village.-Scaffoldings for the dead.Indian Games.-Death of Mr. Chardon.-Page 175.

\section{CHAPTER XI.}

Another Hunting Expedition.-The Turtle Mountains.-Dangerous Hunting Country.-My last Buffalo-hunt.-Sold by an Antelope. - Attacked by and kill a grisly Bear.-Her cub shows fight. Depart from Turtle Mountain.-Attack a grisly Bear.-More grisly Bears.-Mr. Denig's Adventure.-Bear smashing a Buffalo. - Murray and his Mackinaw boats.-The Pipe of Peace.-Shake hands with an old Enemy.-An Indian Battle.-Cannibalism.Arrival of the Martha.-Death of poor Smith.-Page 189.

\section{CHAPTER XII.}

Leave the Indian country.-A blasted Cannon.-Mr. Mackenzie. -Ishmah forages for himsel.-The Yellow Fever.-Doctor Farrell.-General Taylor's Address.-_"Beauty's" History and 
Adventures.-Marriage Feast.-My pretty Hostess.-A Musical Smash-Bruin takes care of Number One._-"Beauty" creates a Sensation. - Bruin rescues the Antelope-The Balize.Page 207.

\section{CHAPTER XIII.}

Snipe and Duck-shooting.-Norwegian Sportsman.-A wounde Alligator proves a disagreeable Boating Companion.-Negro torn by an Alligator.-The Falcon,-Chagres. - Storming the Spanish Fort.--Tropical Thunderstorm.-Panamà.-Santa Anna Cathedral. - The Pope inexorable. - Home by English Mail Steamer.-Page 222. 


\section{RAMBLES AND ADVENTURES.}

\section{CHAPTER I.}

The Start.-Gen. Tom Thumb.-Halifax.-Astor House._Ameriean Railways.-Philadelphia. - Baltimore Beauties. - A Clinical Professor.-Mark Tapley's Eden.-The great Missouri.-Drinks. New Orleans.-Night Adventure. - Creole Ladies.-Col . White's Oratorio of "David."

AFTER all, "ce n'est que le premier pas qui coûte," thought I, as the long row of busy docks at Liverpool slowly receded in the distance, and we bade a last farewell to old England, as the gallant Cambria steamed majestically down the broad waters of the Mersey, in the ever-to-be-remembered year of Grace 1847.

With all the eagerness of a college student, who casts aside his dull books and duller tutors for a burst after the partridges, or for the more noble and exciting pursuit of the antlered lords of the forest and mountain, had I looked forward to a visit to the New World; determined to make acquaintance with our TransAtlantic brethren, and to extend my visit to the regions still inhabited by America's aboriginal people,-now, indeed, driven far westward of their rightful territories, and pressed backwards into that ocean of prairies extending to the foot of the great Rocky Mountains.

It was with something like a sense of disappointrnent, that, the excitement of our departure over, the last friend shaken by the hand, and the last hurried farewell exchanged, I felt that what I had so long dwelt on in anticipation was at last about to be realized; so 
inconsistent, indeed, is our nature, that our keenest yearnings often lead but to our bitterest disappointments, and the possession most ardently sought, affords, when attained, but too frequently the least gratification.

The bustle incidental to a start, when a large number of passengers are on board, affords, however, little time for philosophizing. At first the luggage seems inextricable, and the confusion interminable; but time, patience, and preseverance gradually dispose of all our difficulties, and we shake into our places very soon after the docks are cleared.

I found on board some very pleasant and entertaining* fellow-passengers, and was not a little surprised, on entering the state-cabin, to hear the most unnatural shrill little pipe exclaiming, "Waiter! bwing me a Welsh wabbit." After some difficulty I discovered its possessor, who, creeping from under shawls and ladies' workbaskets, scrambled into the middle of the saloon, stuck his Lilliputian hands into his little pockets, and looked at us as much as to say, "What do you think of that?"

We found little "General Tom Thumb" a very amusing companion; and any of my readers who may have experienced the dulness of a sea-voyage can imagine that he proved a most acceptable addition to our society: he was the smallest specimen of human nature it has ever been my lot to behold, but a remarkable exception to the generality of dwarfs, being not only intelligent, but active and well-proportioned.

There he stood, sprucely attired in a little midshipman's dress, his tiny patent-leather boots the miracle of a fit.

Early next morning we passed along the south coast of Ireland, recognising successively Dummore, Tramore's three towers, with its colossal metal man stretching forth his threatening arm to warn the mariner from 
that inhospitable coast, and, finally, Ardmore's round tower-the last aged memorial of the Old World.

But-

Hurrah, the bell for breakfast!

Hark to the mingled din

Of knife, and fork, and hissing chops

That stewards are bringing in.

The fiery skipper's pricking fast

His fork into the dish,

Despatching quickly his repast

Of coffee, eggrs, and fish.

In burst the guests, and on they rush

Around the jolly tar,

Who calls on semi-seasick folks

To prosecute the war.

And a right good breakfast we had, for the fare on board the Cambria was unexceptionable, combining all the excellences of American, English, and even French cookery. Alas, however, even the means of fortification provided by a batterie de cuisine Française was no sufficient protection against the fell sea-serpent monster, who soon numbered many of my fellow-passengers among his victims. A strong head-wind and chopping" sea made many a mournful gap among the ranks at our capital table. But the severest misfortune of all was the total loss of our ladies' society ; they, poor things, suffering so severely as to be entirely confined to their cabins till within a short period of our arrival.

The little General, however, remained unscathed, and, despite the too audible miseries of most of his fellow-passengers, held on the even tenor of his way, swallowing his toasted cheese and sipping bottled porter. I was particularly favoured with his notice. A great amusement of his consisted in climbing all over me; now standing on my shoulder, then balancing himself on my head on one foot, and finally leaping into the pocket of my shooting-jacket until he burst through the lining of it. He was, on the whole, a very good, 
tractable little fellow, and listened attentively to my lectures on the evils of play ; but, alas, I fear they had but small effect, for the little wretch was an inveterate gambler, and up to all the mysteries of whist, hewker poker, and bragg. I forget at present his exact height; but, as far as I can recollect, he measured twenty-four or twenty-five inches; had light hair, a pretty childish face, was about sixteen or seventeen years of age, and weighed fifteen pounds - the weight of a good-sized leg of mutton. Barnum, the well-known entrepreneur, was with him constantly, and behaved with the utmost kindness to his young charge, never urging the child to do anything to which he showed much disinclination, yet, at the same time, exercising a very nccessary and wholesome authority over him. His father and mother also travelled in his suite, and were certainly above the average height: his mother appeared a kind and amiable person; she informed me that she had two daughters in Canada, where she usually resided, and that she, her husband, and relatives were Canadians, and the little General, consequently, a subject of her Majesty Queen Victoria. Some of my fellow-passengers told me that Barnum had, by the exhibition of Tom 'Thumb, cleared in a few years the enormous sum of $100,000 l$. It is satisfactory to add, that I was informed he had acted most liberally towards the parents, having greatly increased the stipulated amount for the little General's exhibition.

About the middle of the passage, a conversation arising relative to the sufferings of the poor in Ireland, an American gentleman sugrested a subscription in aid of the funds then raising for their relief ; and the proposition having been ably seconded by a Canadian merchant, the result exceeded our expectations, in a collection of $120 l$.

About this period the weather became more severe, 
and the motion of the vessel, consequently, very trying to those who had not yet got their sea-legs; but the wind suddenly fell one afternoon, and I shall never forget the magnificent sight afforded by the masses of unbroken waters as they reared themselves aloft ahead, and threatened us for a moment with annihilation;then, while bearing us up to heaven, fled away from under our feet to unite themselves with the horizon in our rake. Descending the steps of the companion to the dining-room was strongly suggestive of the descent from the sublime to the ridiculous. Legs of mutton became animated, sirloins of beef whirled along like boomerangs from one end of the table to the other, spreading devastation on every side, and effecting strange combinations of soup and sausages, pickles and port wine, custard and pudding floating in bottled porter, \&c.

The first land we made was Halifax, where we found it necessary to put in for a fresh supply of coal. During the very short delay of the Cambria in port, I seized the opportunity for a stroll through the streets of the tomn; but the night was so intensely dark that I could see little to describe. The ground was covered with snow; many sledges I passed seemed to be very handsome equipages; the horses attached to them bearing bells round their necks, or perhaps fastened to their collars, for the greater security of the foot-passengers, who were thereby warned of their approach in sufficient time to get out of the way. It was very cold weather; and we left the harbour again in about three hours after we had arrived, the business of taking in coal being transacted very rapidly.

Between Halifax and Boston our voyage was most prosperous; the weather so beautiful as to entice our ladies once more on deck, and all eyes were turned westward to catch the first glimpse of land. The pilot 
from Boston boarded us the following day, and we soon rode triumphantly in, greeted by shouts and cannon from the surronnding vessels in the harbour.

After our luggage had been cursorily examined at the Custom House, we stowed it and ourselves, as we best could, into the different vehicles destined to convey us to the several hotels to which they belonged; and I cannot help remarking the great contrast between the different methods adopted, with respect to strangers and their luggage, in the Custom-house searchers of our orn and most other European countries, and of that of our Trans-Atlantic brethren; while I may observe that courteous treatment, in that it gratifies the feelings of a stranger, has also the effect of disarming and dissuading him from any attempt at fraud or concealment.

I could expect to find but little that mas new in a place so often described as Boston. I discovered one fact, however, which may interest future travellers; viz., that smoking is not allowed in the streets at night; for, having lighted a cigar, I was quietly strolling along the pavement, when I was accosted by a casual passenger with, "Sir, I guess you are a stranger !"-"Sir, you are an uncommon good guesser," was my reply; but I soon found by the sequel of our conversation, that, however abruptly it had commenced, the motive of my querist was a kind one, and that I was committing a breach of the laws, which might have subjected me to a severe penalty.

The American Hotel in Boston is an excellent one; and the rooms being heated with hot water renders them most comfortable, notwithstanding the extreme coldness of the weather.

Between Boston and New York the journey was performed partly by railway and partly by steamboats of the finest class, most luxuriously fitted up. The 
eaptain of our boat prudently remained all night at New London, on account of the weather, of which these boats are by no means independent. Next day we resumed the railway once more to New York.

An American railway-carriage reminds one a little of Wombwell's waggon for transporting wild beasts, so far as its external appearance is concerned; and there is abundance of room inside for the passengers to walk up and down, the seats being so arranged as to allow an uninterrupted passage from one end of each carriage to the other. They contain open stoves, round which you may sit occasionally, and change your place from time to time, which all those who are in the habit of travelling know to be a great luxury; besides this, the carriages themselves are so closely chained together in succession, that you can walk from one end of the train to the other. The seats, or benches rather, in the carriages are ranged in rows down each side of the passage, and at right angles to it, except in the vicinity of the stoves, where passengers are at liberty to sit in any direction they please, on camp-chairs left for that purpose. I may also here mention a very good regulation adopted with regard to the luggage: brass tickets are chained to each separate trunk or portmantear, and duplicates of these tickets are given to the passenger, who need have no further trouble with his luggage than giving them to a help (i.e. servant) on arriving at his destination.

At New York I stayed at the Astor House, a magnificent "block" (i.e. building), far larger than any hotel I ever beheld in the Old World. Nany of my readers will doubtless remember the hotel of $l$ 'Empereur" Roman, and l'Hôtel de Russie, in Frankfort: the Astor House, I thought, strongly resembled these, though on a still larger scale-indecd I doubt whether it be not larger than both these hotels put together. The plat- 
form anterior to the huge hall-door is reached from the street by double rows of large stone staircases. The charges I found moderate. Breakfast, dinner, and supper are performed much in the same way as at the table d'hôte on the Continent, except with far greater rapidity. At breakfast here, I ate for the first time cakes made from the flour of buckwheat, which I thought excellent, and deserving a place among the many luxuries of even an English country-house: in shape and size they resemble a muffin; in consistence, a pancake; but they are rougher, and of a dark-brown colour. These cakes are eaten either with butter, like muffins, or with refined molasses, contained in glass jars, shaped something like claret-decanters, which are placed at intervals all along the extensive breakfast-table. Neither is the hominy, which consists of rice and Indian-corn meal, mixed and fried in butter, to be despised. The waiters were Irish, Germans, and men of colour.

I started about the 25th of March, on a cold but brilliantly beautiful day, at about nine o'clock in the morning, for Philadelphia, and, on my arrival, drove immediately to the Mansion-house Hotel. Having no time to lose, I walked out to see the town; and although I was in some degree prepared to like Philadelphia, I had no idea what a splendid city it is ; its beautiful houses being very regular, and mostly built of brick; and, from their wide pavements, the excellent repair in which they are kept, and the splendid shops and lofty buildings, the streets struck me as being really magnificent. The extraordinary cleanliness of the city particularly attracts one's admiration: it is occasioned principally by the abundant supply of water which is afforded by the waterworks of the Schuylkill: handsome cast-iron pumps are among the most prominent features in the streets, and its public buildings are botb graceful and classical. 
After a hasty dinner, attended by four huge, clean, jolly, sable vagabonds, whose language, peculiar pronunciation, and absurd attempts at jokes amused me greatly, I resumed my journey by railway to Baltimore. The view as you leave Philadelphia is very beautiful. For some distance, as you recede from the town, you behold the whole city stretched out before you, forming a splendid panorama. On the right, above the town, are the celebrated waterworks by which it is supplied with water from the Schuylkill, and to the left is the broad estuary of the Delaware, covered with vessels of all sizes, from the light pilot-boat to the lordly threedecker.

We reached Baltimore the same evening. This rapid. journey southward causes, in the course of one single day, a most sensible change in temperature and climate, such as we might perhaps experience in the Old World, if we were to breakfast at Moscow and dine at Naples.

Into Baltimore, according to Jonathan's go-ahead. principles, we drove the train, right through the streets, to the imminent danger of the lives of its peaceful citizens, though not of their liberties, there being no barrier to prevent their getting up a little Juggernaut oblation of themselves to their favourite goddess. In the railwaycarriage, I sat next a gentleman who, from natural politeness, or from a lively dread of Dickens and 'Trollope, restrained himself from spitting out of the window, which was at my other side; but when the exigencies of expectoration required, took off his hat and tested its waterproof qualities in a manner not yet usual in this part of the world. I inferred from this that he must have heard of the American in England, who, spitting across a fellow-passenger out of the window of a stage-coach, learned how little his apology was appreciated when he observed, "I guess I cleared you."

Baltimore is mostly built of brick, but there are also 
many handsome stone buildings, and it is altogether a noble city. I had little time to see much of it, but was struck with the principal streets, which, both in size and paving, \&c., are equal to any I ever saw. The shops are handsomely lighted up in the evening, and the crowded streets exhibited a numerous and welldressed population. I had heard of the beauty of the Baltimore women, and was not disappointed in them, for I never saw so many pretty faces before in so short a time.

A splendid fire took place that night in Baltimore, which was extinguished, fortunately, without any further effects than giving us a good appetite for our supper; the attack on which was most furious, and the consumption far more extensive than that of the fre we had assisted to put out.

At Cumberland, we took the stage-coach across the Alleghany range of mountains to Wheeling, which is not far from the head of the navigation of the river Ohio. An American stage-coach is a very primitive, rough sort of conveyance, something like the diligence on the Continent, but far stronger in construction, both as to wheels and springs, and calculated to meet the very severe shocks to which the nature and state of the roads necessarily subject it. It is built to accommodate, or rather torture, nine persons inside, and as many outside as have the skill or the courage to sit along with the driver. This functionary is truly a wonderful man. He drives four horses, at a very tolerable pace, over a road where the depth of the ruts and the number of stumps of trees baffle description. When the wheel strikes one of the latter, the centrifugal effect is sublime. The top of my head was so battered against the roof of this notable conveyance, that, after a while, I preferred sharing the driver's fortunes outside, notwithstanding the cold encountered among these hills, from 
which, however, the continual exertion of clinging on was quite sufficient to prevent my suffering. But how our Jehu contrived to drive, to manage the drag (which he did by means of a screw handle on his right), and to remain on the box, is a mystery that to this day I am unable to solve. This road the coachman declired to me to have been usually a very good one, although it unavoidably fell into a bad state of repair in winter.

I never satr a more beautiful range of mountains than the Alleghanies-full of deep dark gorges and ravines, through which the road winds, now under lofty precipices, reminding me of some of the passes in the Tyrol ; now along a high crest of mountain, overlooking a vast extent of beautiful country; now through some thick primeval forest, capital lurking-places for bears, wolves, and panther's, or painter's, as they are there called. During a great part of the day, we travelled up the Monogahela River, celebrated all over the States for the whiskey made along its banks. Every now and then we made a rapid descent at full gallop down some deep gorge filled with snor, into which, at this season, the beams of the sun never penetrate. Coal of the finest kind is found all through the Alleghanies in great quantities, and in the towns along the road it is to be bought at four and sixpence a ton.

I reached Wheeling, heartily sick of stage-coach travelling, but consoling myself with the reflection that the rest of my journey to New Orleans was to be by the river.

Here I first beheld those justly celebrated American river-steamboats, so indicative of the enterprise and commercial prosperity of the country. By means of these vessels, the productions of the most remote parts of the interior are transferred to suitable markets at a trifling expense to the producer; so that the furs and skins from the remotest savages, the wheat and Indian 
corn of the agriculturist, the cotton and the sugar of the planter, are rendered valuable and profitable by the free choice among the many market-towns studding the banks of its rivers, from the remote Missouri, Ohio, and Arkansas, to New Orleans, where the Mississippi rolls its vast united flood into the waters of the Atlantic Ocean. These boats are flat-bottomed, and not built with a view to durability; a fact which, together with the economical manner of their construction, renders them often very dangerous to the lives and limbs of the numerous passengers that crowd their decks.

Much has been said of the comparative merits of the high-pressure and low-pressure engines; but I am inclined to believe that the high-pressure engine would be quite sufficiently safe, provided the captains of the boats were chosen a little more judiciously from men conversant with steam-engines in general, and particularly with the nature and capabilities of the machinery under their command. It is true there is a practical engineer immediately controlling the said machinery; but the poor fellow is frequently obliged serionsly to overtax the powers of the engine, by the frantic anathemas of the captain-" D-n you, go ahead! fire up there! fire up, will you ?"-when excited either by the speed of a boat astern of him, or by his eagerness to overhaul a "tarnation oppositioner" ahead, who is no doubt bent on securing all the passengers from the next town on the river.

On account of the low state of the water in the Ohio, I took my passage as far as Louisville in a small sternwheel boat. These steamers are driven by one wheel only, which is placed astern; they draw very little water, and are available in places where others could not answer the purpose so well. My travelling companions were very entertaining. Their inquisitiveness amused more than it annoyed me; for I was prepared 
for it, by the accounts of English authors, many of whom, I think, have animadverted on it too severely. They certainly, so far as I myself was concerned, quite compensated me for their tendency to ask questions, by their great readiness in answering them; and I must say I found a general willingness amongst them to be communicative and obliging to a stranger, and the greatest deference towards any one that spins a yarn for them-a tendency to which, I dare say, most of my brother-sportsmen will confess. Who has not, after a hard and successful run in the pursuit of an elk, or a fortunate skirmish with a bear, been inveigled into a minute detail of the chase or contest, with a description of every trivial circumstance, from the start to the death ? or, even after its lucky termination, who has not dilated on the fine condition of the animal, and the size of its horns, boring you with his sensations as he strides beside his weary horse, heavily laden with the trophies of his successful encounter? However, we must hope that the world is very charitable, and allows a fair license to sportsmen, as well as to other enthusiasts.

The next day we were thrown into great confusion on board, by the announcement that one of the ladics was about to contribute an additional little member to our society. At the time she was taken ill, I was sitting in the cabin talking to an amusing youngster of some seventecn years of age. I could not better describe him, than by referring my readers to the portrait of Bob Sawyer, in "Pickwick," of which character he very strongly reminded me. He wore a rough blue coat, which he had decidedly outgrown, for the sleeves were far up his arms; shirt-sleeves. he had none-at all events they did not figure in the visible of his costume, which really was very perfect without them, especially as its style was consistently maintained by a total absence of shirt-collar. He for some time eagerly 
observed the lady's husband, who was just then deploring the absence of medical aid, and imploring the captain to do some such impossibility as to put the vessel about, and go back again, when my Bob Sawyer broke in at the top of his voice, with "Hullo, mister, now don't rile yourself for nothing ; I'm a medical man, and passed in clinicals, and will fix her nicely and handsomely;" then jumping up, and slapping the poor old negro nurse (who was in tears) on the shoulder, added, "Come, look alive," and ran in to the assistance of the invalid. forthwith. In less than half an hour he sauntered. slowly back to his seat, and calling to a friend, observed, "I say, Tom, an almighty fine boy, and rich folks, I calculate ;" and then proceeded to discuss with him the propriety of asking twenty dollars for "the joh," as they termed it; Bob Sawyer, in the difficulty of agreement, even doing me the honour of appealing to me. I could only suggest a valuation of the baby, and a commission of so many cents on the dollar. This would not do, however. Tom was conscientious and firm, said that it would not be right to take an unfair advantage of the way in which the gentleman and lady were circumstanced, and that his friend ought not to ask more than the regular fee of eight dollars. What the amount ultimately received by our clinical professor was, I did not learn; but the next morning I observed him called aside by the old black nurse, who took him to visit her mistress, whence he presently returned to me, vorring the lady's husband to be "a real trump, and an almighty fine gentleman, by G-!" We-arrived that day at St. Louis, where it had been the lady's intention to have remained for her confinement and recovery; but the poor thing was obliged to stay on board instead; and I felt for her when I heard the deafening continuous roar of the steam-escapement close to the cabin where she was a prisoner. 
As I intended returning to Louisville again, I stayed there but one day, and proceeded on another boat bound for St. Louis (Missouri), as far as Cairo, at the mouth of the Ohio, where that river joins the Mississippi. On landing and looking about me, I soon became convinced that Cairo must be the spot that suggested to Dickens his description of "Eden," and Martin Chuzzlerrit's and Mark Tapley's doings there, when bent on seeking" their fortunes in the Western States. Cairo really is a dreary waste. Great exertions rere once made to bank it up and reclaim it, by damming the rivers, so as to form a site for a market-town; but all attempts have hitherto utterly failed, and it still is, as it will I think long remain, an unhealthy swamp. The hotel, when I was there, was a floating one, constructed out of a condemned river-steamer, the lower part of which was fitted up as a store or shop, the upper part requiring no change in its internal arrangements.

I went outwith my double-barrelled gun, whilst waiting for a New Orleans boat, and after some mading, brought back several ducks and quails. Early next morning $a$ Mississippi steamer passed, and in her I took my passage for New Orleans. The Great MIissouri was then the most splendid vessel on the river, and plied between St. Louis and New Orleans. The ladies' sitting-room cabin was most beautifully furnished, affording all the luxuries of sofas, rocking-chairs, and a pianoforte. This room, as in all river-steamers, is a continuation of the general dining-cabin, the ladies having the power of shutting it off at any time in the evening, when they wish to retire, by pushing together concealed slidingdoors, which meet in the middle. The sleeping-cabins are ranged along the sides of this saloon, the doors opening inwards from it. Each of them contains two berths ; but when there are not a great many passengers, you can secure the whole room to yourself by paying a 
little more than the usual fare. Outside these, again, there is a passage round on the deck of the steamer, enabling the passengers to walk about in the open air protected from the sun's rays by the hurricane-deck ; and from this external walk there are glass doors into the bed-rooms on the side opposite to that by which you enter from the dining-saloon. The hurricane-deck overhead is supported by stanchions, connecting it with the passengers' deck, on which it stands. On the hurricane-deck, again, is placed the pilot's glass house or caboose, covered with a wooden roof rendered waterproof. From his position he can command a good view of the river-a power he stands much in need of in order to avoid the numerous snags and shallows which perpetually present themselves ahead, threatening the safety of the boat. I ought here perhaps to inform my readers that a "snag" is a tree, or part of a large tree, whose progress down the river has been arrested by the accumulation of sand or carth, or some such cause ; and as it is frequently quite hidden from view, the experienced eye of the pilot alone can discover its presence by the peculiar ripple of the water at the spot where his dangerous enemy lies concealed. A keen power of observation in this respect is only to be acquired by long attention and practice, like that arrived at by the hunter who tracks his game on the prairie.

We proceeded at a tremendous pace in this beautiful boat, averaging eighteen or nineteen miles an hour, the stream running strongly in our favour. We passed vast tracts of forest on either sidc, chicfly consisting of cottontrees, presenting various successions of growth, which have a very pretty effect, and are caused by the river, on account of its abrupt curves, continually changing its course, and those banks of sand and mud which it consequently abandons receiving from the wings of the wind into their genial soil the seeds shed by the old patriarchal 
trees. The successive gradations of the miniature woods thus formed make a pleasing variety in the otherwise monotonous character of the landscape, and often suggested to me reflections on the similarity in the human world of the progress of population from mother-countries to their colonies. The principal use made of the cotton-tree is to provide fuel for the steamers, which is hern down, cut up, and piled by contract on the river's bank, and carried on board by the crew called the deck hands of the steaner. This operation of taking in rood occurs about three times in the twenty-four hours, and occupies about an hour and a half at each time, the men having to carry the $\log s$ on their shoulders along a couple of planks thrown out from the side of the boat on to the bank; so that you can frequently go ashore while the boat is " wooding."

Life on board a river boat resembles life at an hotel, only it is a great deal pleasanter. A bell rings a little after sunrise : you get up and proceed to the washinglouse, next to which, by paying a few cents, you can have a bath. At your exit from this you will most likely find a grinning negro barber bowing and scraping at the bath-room door, soliciting permission to test upon your chin, for a trifling consideration, his powers of easy shaving. That operation has hardly terminated when you hear the bar-keeper vociferating, "Now, then, gentlemen, come on; come on; choose your drinks. What shall I fix you, sir?" Then commences the dynasty of brandy-smashes, mint-juleps, gin-slings, and whiskey-cocktails, and you may finally observe some of the gentlemen sitting down to breakfast with tears in their eyes, the effect of some awful gulp of alcohol and wormwood, elegantly denominated a phlegm-cutter. A bell gives the signal for breakfast, but even before that time you will see each man standing behind his chair, holding it tightly by the back, and ready to vault into 
his seat as soon as the iron tongue, impelled by Snowball's sable arm, strikes the galvanic shock among the guests.

The captain sits at the head of the table and his lieutenant at the foot ; opposite to each of these gentlemen is placed a large dish of hissing-hot beefsteaks, on a pewter receiver filled with hot water, which is kept boiling by a spirit-lamp placed underneath. The guests are attended by negro servants, who hand about coffee, tea, \&cc. After the first breakfast is served the second breakfast, for the officers and those that are not exactly passengers, after which follows the third breakfast, for the people of colour. The passengers, while all this is going on, sit outside and in front of the cabin, smoking, and reading the papers, which they always have the opportunity of exchanging for later nerrs at the different towns where they touch for freight or passengers. Your day passes cheerfully from the consciousness of proceeding at a rapid rate towards your destination, coupled with the enjoyment of being able to read and write at your ease, and having plenty of room to eat, drink, smoke, and enjoy yourself. Previous to the announcement of dinner, the passengers again assemble at the bar, the keeper of which is at his post, displaying prodigies of activity in supplying the demands of his customers, some of whom keep him pretty well employed until the dishing of dinner commences, when they fly to their chairs as at breakfast. During dinner scarcely anything was drunk but water. After the cloth was removed the company removed themselves, and not even a glass of wine was called for. I completely failed in getting an amusing acquaintance to assist me in discussing a bottle of Madeira, the invariable answer to my request being, "I thank you, I have eaten my dinner."

The habit of taking these stimulating drinks before eating is attributable to the relaxing influences of the 
climate in the southern States; the stomach requiring a kind of tonic to provoke an appetite and strengthen digestion. I do not think the habit a good one, having always found, in my experience of hot climates, that stimulants do more harm than good when taken with the view of acquiring an appetite; the safest way being to wait without eating until the appetite arrives, or, if possible, treat yourself to half an hour's sleep before dinner. I subsequently found that in the large towns the custom of drinking wine in the English way, i.e., leisurely and sociably after dinner, is gradually becoming the habit of the wealthier and more influential merchants.

Occasionally, though not frequently, you meet the most eligible society on board the large river steamboats, particularly when the hot season induces many of the higher classes of society to migrate northwards, at which period they frequently form parties to travel together; and on these occasions, when the party thus formed has been so attractive as to include many agreeable young ladies, I have often known young men (old acquaintances, perhaps) join it expressly for the river voyage and the pleasure of their society, and enjoy lots of music and dancing in the spacious ladies' saloon purposely fitted up for that object.

We proceeded rapidly southward, passing frequent cotton plantations, which afford almost constant light work to the negroes, both in keeping the crop free from weeds, and finally gathering it; till, at last, the whirling panorama on each side of us rolled Missouri and Arkansas from our view, revealing to our eyes the lands and sugar-plantations of Louisiana.

As you approach New Orleans the scene becomes very interesting, and the eye is greeted with a strange contrast of luxuriant plantations studded with orange trees, where aromatic shrubs and rare plants may be traced to the gentle hand and graceful taste of the high- 
born Creole lady, gradually and diffidently intruding themselves on the vast outskirts of dreary forest, dismal swamp, and impenetrable cane brake. New Orleans cannot fail to strike a visitor with vivid emotions of pleasure and surprise. It is, you may say, reclaimed from the river by banks called "levees," somewhat in the same manner as in Holland. The town is divided into several municipalities, and though these are separated one from another by but a single street, yet on one side of it you may imagine yourself in England, and on the other forget that you are not in France-so strongly are the characteristic differences marked in all you see around you; in the buildings, manners, even in the sign-boards over the stores and shops, which are printed in different languages in the opposite municipalities. This difference is quite as remarkable in the inhabitants themselves. The American is essentially English, despite his affectation of the contrary; he is so in his business habits, in his conversation, in his preference for spending his evenings at home with his wife and family, instead of at public amusements. The Creole, although his position may be that of a man of business, is yet quite wanting in the daring speculation and unremitting industry of the Anglo-Saxon; seeking to support himself by economy and bargaining, while the American is striving to increase his fortune by extending his operations. It is of his time, not of his money, that he is economical ; of his dollars indeed he is most liberal, and frequently lavish. The Creole considers his business at a certain hour of the day terminated, and his unambitious evening is devoted to the journal, the Thêâtre Français, and a cup of coffee. The American, if occasion require, will burn the midnight oil in his office, and may often be found at two o'clock in the morning winding up the pressure of additional business for the departure of the weekly British steamer. 
Upon landing I went to the St. Charles Hotel, an enormous building in Grecian architecture, with a fine St. Paul's-like dome, more resembling' a large cathedral than a hotel, and presenting a most imposing appearance from the river. There, however, I did not remain long, for on presenting my letters of introduction I dined with some new triends, who persuaded me most kindly to take up my residence in their house during my stay.

There is a great charm about New Orleans: the old style of Spanish architecture wraps round it a feeling of romance which, alas! there is so much in America's civilisation calculated to suppress.

The verandahs, portes cocheres, and small Creole houses, built of wood, only one story high and opening into the street, are very picturesque. I enjoyed myself greatly there, and shall never forget the kindness and hospitality that greeted me on every side. Among the Creoles there is a simplicity and cordiality that soon induces the stranger to feel himself at home with them, particularly if he is from "la Grande Bretagne," in which case he is sure to meet with an universal welcome.

I ought here perhaps to explain to my readers the strict meaning of the term "Creole ;" at all events, the sense in which the word is used in America. Creole means born in the country; and the term is generally applied to the descendants of the old French and Spanish founders of the colony: indeed you could not offend or hurt the feelings of a Creole gentleman or lady more, than by supposing either of them even in the remotest degree of coloured origin. The marked distinction which I found in the French and English parts of the town, as I have already described, I found as strongly characterised among the inhabitants. The Creole, rich or poor, you can easily distinguish by the French cut of his clothes and hat, and perhaps a 
French-trimmed beard. Probably he is dirty and unshaven, chary of displaying too much or too ciean linen. Look at the American over the way as he rolls along, his clothes not made by "a tarnation French snip," but all bought at the ready-made clothes store: his face is well shaven, and although he wears a beard, it is not allowed to trespass on the chin: he wears no gloves, but his hands are always clean, and so is his scrupulously white linen, of which he makes rather an extensive display, for he seldom wears a waistcoat, and his loose coat is always unbuttoned. In his bosom he wears a large pin, may be a diamond, may be a piece of glass. Well, go ahead Jonathan : with all your faults (and which of us is without them?) you are a fine, noble fellow!

How difficult it is to admire and appreciate without comparing! Comparisons are odious; but avoid them you cannot, when the contrast betrreen the American and the Creole lady is so strongly presented to the stranger's observation as on his introduction to New Orleans socicty. The poor American lady is like an exotic plant. In the first place, the climate disagrees with her: she is languid from the heat, and her good looks rapidly fade. Then she dresses badly, though expensively ; her choice of colours is extensive but not good, and when she is dressed her clothes cling about much as you could fancy they would had she fallen into the river and been drawn out again. If she dances she does so arkwardly, and a quadrille or two (for she seldom ventures on a higher flight) soon fatigues her.

The Creole, on the contrary, combines the naïreté of the Spanish girl, with the polished elegance of the French lady, whose toilet she scrupulously imitates. Though not expensively dressed, her beautifully rounded figure is attired with an exquisite neatness that makes her at once the ornament of the opera, and the light and 
life of the ball-room. She is passionately fond of dancing, in the enjoyment of which she is as graceful as she is indefatigable.

I had taken apartments in the Rue Royale, situated in the old Spanish-looking part of the torn. The similarity of many of its buildings led me into a strange mistake, which I mention here as indicative of the absence of all apprehension of danger at night from robbers, or any other cause. On my return from an evening party, I wandered up and down the Rue Royale by the light of a beautiful moon, which was then at its full, at which time the lamps in the streets are not lighted, nor indeed are they needed; and the absence of all artificial light greatly contributed to the beauty of the quaint old Spanish buildings along the street, as they reflected the moonbeams in strong relief with the dark shadows they show in their wake. The weather being very warm, door's were thrown open, muslin and gauze curtains fluttered from open windows, as if waving in invitation to the cooling night breeze to come and refresh the slumbers of those who heavily slept inside. After wandering up and down some time, while finishing my half-smoked cigar, I suddenly became aware that I mas unable to discover my lodgings, my observation of that morning not having been sufficiently accurate to enable me to recognize any difference between one house and another, in the pale, uncertain moonlight. After a little hesitation, I entered that which I thought most probable to be the right one; and passing through the porte cochere, I went upstairs, found doors and windows all thrown open; and I continued for some time wandering through rooms where the gilding of beatiful pictures glanced in the moonlight. I had not gone far, when I felt I had mistaken the house. Curiosity, however, induced me to wander a little further, before retracing my steps. My situation forcibly reminded me 
of the account of Don Alphonso, in Gil Blas, when driven by the storm to take shelter in the old Spanish house, through which he continued wandering from room to room, amidst splendid furniture, partially lighted by expiring lamps, until he reached the apartment of Seraphine, where he found the beautiful widow sleeping heavily and uneasily, through the sultry Spanish midsummer night. These reflections, however, were quickly interrupted by a lady's voice, calling out, "Who is there?" I replied hastily, informing her of my having taken apartments in the Rue Royale that morning, and also of having forgotten both the number of the house and the name of its owner. "Was it Mr. So and So's, or was it Colonel S.," she kindly suggested ; but quite in vain ; nothing could bring it back to my memory. "Well," at length she replied, "as my brother is gone to the country, you can sleep in his room to-night. Take the first turn at the foot of the steps, cross the large landing-place, and go into the room at the head of the large stairs. Stay, I will give you a light." After a short pause, I heard, at the other side of the closed door, a crackling noise, announcing the ignition of a lucifer match, and immediatcly afterwards a lighted candle made its appearance, as well as a very pretty little jewelled hand, neatly pressed at the wrist with a very pretty little lace frill. Having taken the proferred candle, I thanked my hostess, and easily found my way to the room she had described, where I slept most comfortably. In the morning I was awakened by an old negro woman, who brought me a cup of coffee, returning, before my toilet was completed, with a pair of handsome ivory-backed hair-brushes, belonging to her mistress, together with her compliments to know if I had slept well. I made acquaintance with Mrs. C., the heroine of this adventure, in society afterwards. She laughed heartily at it, and said she had not been in the 
least alarmed. The idea of any one having come in to rob the house had never entered her head.

Soon after my arrival at New Orleans, I accompanied Colonel White on a visit to his sugar plantation, about thirty miles down the river. He had been away for some time; his arrival in the evening was, therefore, a signal for general rejoicing among his negroes, who lighted a bonfire on the bank of the river to celebrate the event. I was much struck at the evident delight they evinced at seeing him once more among them, as the more favoured ones crowded round to shake hands with him. How different, thought I, from our preconceived notions in England, of the condition of negroes in the slave states of America-an impression still further confirmed, when I subsequently visited their neat little drellings.

The colonel's house was very comfortable, surrounded by a beautiful, well-kept garden ; and by his sugar plantation-a very extensive one, and admirably well managed.

Early the next morning, a neatly-dressed old negro roman, with a coloured cotton handkerchief tied round her head, arroke me, bringing me at the same time a cup of hot, strong coffee, to assist me in shaking off the shackles of the drowsy god. I then rose, dressed, and joined the colonel in a ride through his plantation; returned to a capital breakfast; after which we visited the different houses and machineries connected with the manufacture of the cane; the colonel, from time to time, endeavouring to initiate me into the mysteries of sugar. At ten o'clock we dined, after which I started off to wage war on the snipes, which I found in abundance in and around where cane had been, and in swampy patches where the reeds were cut away. The colonel continued riding about on horseback, contemplating the sport. In many places the reeds were so thick, that it was difficult. to find those birds that happened to fall dead; however, 
I bagged twenty-one brace out of twenty-three and a half, to the great satisfaction of the colonel, who enjoyed the sport quite as much as myself, accompanying the fall of each bird with a hearty cheer.

In the evening, the colonel produced a bottle of old Irish whiskey, giving me, after supper, and over our tumbler of punch, an admirable description of the battle of New Orleans, at which he was himself present, being an aide-de-camp and particular friend of General Jackson's. The attack of the English he described as a splendid one ; but, considering the circumstances under which the Americans were entrenched, and effectually protected by their admirable breastwork of cotton-bales, it must have been-as the event subsequently proved-a most unadvisable undertaking. The colonel, indeed, with an oath, declared it the most frantic piece of infatuation on the part of the English General, only to be accounted for on the supposition of his being drunk at the time.

The lie of snipes is most uncertain, and the place where they abound to-day will be abandoned by them to-morrow. The following day, I found but five birds on the spot which had afforded me the greatest number of shots the day before; of these I fired at and shot three, and the next day-before starting to Nerw Orleans-I ran out and finished the other two, before the steamer arrived by which we returned to town in the evening. On my return to New Orleans, I found a grand musical performance, in the shape of an Oratorio in process of rehearsal, for the purpose of raising funds to defray the expenses of the new organ for the large Episcopalian Church in Canal Street, and all the musical amateurs of the town hard at work getting up the oratorio of "David," composed by Sigismond Neukomm. The conductor, Mr. Courteau, who was acquainted with me, requested me to join, and persuaded me to take one of the solo parts. 
Shortly after this the general rehearsal came off in the church, with organ and orchestra. The choruses went beautifully; but the solos were decided failures, the amateur voices not being either sufficiently powerful nor sufficiently trained to support solo parts in so large a building, with an orchestra. The committee mere obliged to obtain the assistance of the singers of the Italian Opera-Madame Fleur Jolie (Prima-Donna). Madame Favi, Mrs. Wilcox, and the tenore, M. Duffet; all of whom offered their services, without remuneration. The basso, howrever, was too mercenary to follow their example; I was, therefore, obliged to sing his part as well as my orn. When Goliath, therefore, was defunct, I appeared again as King Saul, much to the amusement of several of my friends, who declared that "I took a vast deal of killing, by G-."

I remained several weeks in New Orleans, with my kind friends, passing my time very pleasantly at balls, dinner-parties, and excursions to Lake Pontchartrain, and took my leave amidst hearty farewells and faithful promises to return again to $\mathrm{New}$ Orleans.

\section{CHAPTER II.}

Arkansas forests.-Deer shooting.-The Major's good shots.-FirePan-hunting.-Fine fat Bucks.-Still-hunting.-First night in the Woods.-Panther shot.-Black bait for an Alligator.-Assassination of a Bear.

I Proceeded up the Mississippi and Arkansor rivers, having determined to try hunting in the Arkansas country, of which I had heard a very good report. I introduced myself to Mr. Keatts, the orner of a fine cotton plantation, who hospitably welcomed me to his 
house, and proposed my remaining a day or tro with him, at the end of which time, he promised to accompany me to his brother-in-law's, about twenty miles distant, which place he recommended me to make my head-quarters.

My host's residence was a handsome, comfortable house, built of wood, its large roof and wide surrounding verandah rendering it very picturesque. The day on which I arrived was oppressively hot, so, in the evening; we sat out in the verandah sipping our coffee and smoking our cigars, and surveying the lovely moonlight scene before us. The climate was Italian; in the foreground, the moon's rays capriciously displayed the very beautiful shrubs and flowers with which Keatts had sa tastefully ornamented his garden; and, behind them, the colossal forms of forest trees, not planted by man's hand. Silence, however, was far from reigning over the scene; my European ears being bewildered with the quaint, yet not discordant cries of the Whip-poor-Will, interrupted every now and then, as if impatiently and angrily, by the cry of his rival chatterer, Whip-poorWill's-widow*-sounds differing so much from those of our little musical birds, as strongly to remind me of absence from home, of a new world, and of a creation where "night unto night showeth knowledge." The fire-flies, too, literally "glanced among myrtle-boughs,

* The Whip-poor-Will is rendered Interesting by the mysterious veneration in which he is held by so many of our fair friends in Arkansas, who evidently (although unwilling to confess it) deem him a bird of ill omen. He is a species of the Goatsucker tribe, of a dark brown-colour, with black stripes, and curiously mottled; head not so dark, with an enormous mouth ; a strong bill, slightly curved at the extremity; and is furnished, no doubt for the greater facility: of securing his prey, with long whalebone-like hairs extending beyond the bill. He feeds on insects, is seldom seen on the wing in the day-time, and flies close to the ground, and like a swallow. The Whip-poor-Will's widow is very like him; but perhaps a different species, and not so large. 
as if distracted by the incessant cheeping of gigantic grasshoppers."

Two days afterwards, we were joined by Keatts's brother, an excellent deer hunter, and we all three moved off next morning on horseback to the brother-inlaw's, with guns, saddle-bags, \&c.; and, on the next day after our arrival, sallied forth to commence our hunting; Keatts, who, though an excellent shot, was not a strong man, or capable of enduring much fatigue, taking my double-barrel, intending to operate with buckshot, while his brother and I shouldered our rifles. After riding for a few miles through the most beautiful and likely forest, and along glades of inviting scrub-oak, we came to what is called a deer-lick. These deer-licks are either deposits of salt or patches of land strongly impregnated with salt, to which the deer are attracted, probably by feeling themselves surfeited with the rank grass on which they browse, for they generally feed early in the morning and late in the evening, and the time when they are chiefly to be found at the licks, is after noon and before midnight.

Arrived at a well-known lick, we unsaddled our horses and picketted them, and contrived, by lighting a fire to windward of them, and supplying it with a heap of green wood, to envelop the poor animals in the smoke it created, in order, as much as possible, to protect them. from the attacks of the flies, which prove a perfect pest in this country. This accomplished, Keatts clambered up into a tree commanding a good view of the lick, armed with my double-barrelled gun, while we, with our long rifles, went to seek our fortunes in a rather more laborious way.

We agreed, if possible, to meet on the bank of a little stream, and halt for mid-day, it being then the height of summer. After each had hunted some time unsuccessfully, we met at our rendezvous, but had hardly 
lighted our fire, when we were roused by the snorting and whistling of a deer. I raised myselif slowly on one knee, and fortunately, before he could bound away back into the thicket, planted a bullet behind his shoulder. He dashed forward with his head thrust downwards for a few paces, rolled over, and expired. I was rather pleased at my success, and immediately set to work at skinning him, alas! how awkwardly! I had more difficulty in removing the skin from that one deer, than I should have found, trrelve months afterwards, in shredding off the hides of two bison bulls. But, though my companion assisted me, we had hardly flayed and cut up our game, when I heard my double-barrel go off with a tremendous report. "Hullo, Harry !" I exclaimed, "that report is too strong for my gun ; I am sure all's not right;" and, so strongly were my suspicions raised, that we both started off to see whether anything really was the matter. We were not far from the deer-lick where we had left Keatts, when we heard him as we approached, feebly calling, "Held! help!" and found the poor fellow lying at the foot of the tree in which we had left him perched like a squirrel that morning, but now hardly able to speak from pain and exhaustion, and a fine fat buck (much larger than the one I had killed) lying about fourteen paces off. The catastrophe was in this wise. Keatts, perched up on a branch, contrived in some way or other to let off both barrels of the gun together at the deer, the result of which was the simultaneous downfal of sportsman, gun, and game. The poor fellow was considerably hurt, but much more frightened; fortunately, however, no bones were broken, which, from the height of the branch and the distance he must have fallen, was rather surprising: We paid dear for our sport that day. Poor Keatts was laid up in ordinary for a couple of weeks at least, and I had the felicity of beholding my poor double-barrel shattered to pieces. 
We continued deer-shooting for a few days longer, after which my friend was obliged to return to one of his plantations. The house of his brother-in-law, Mr. Thibault, was a pleasant, hospitable cottage, and himself an excellent sportsman. We rose at day-break, breakfasted at sun-rise on fried venison and pork, corn dodgers, and coffee, and then sallied forth to our shooting, seldom returning before supper-time, after various success, sometimes unfortunate, and sometime with horses heavy laden with the spoils of our hunt. After supper we used to chat over our adventures for awhile, and then turned in for the night.

One evening we determined to go out pan-hunting, a species of sport, which, for the edification of my bretliren on this side of the Atlantic, I must endeavour to explain. It is a method of hunting deer at night. An iron pan attached to a long stick serving as a handle is carried in the left hand over the left shoulder; near where the left hand grasps the handle is a small projecting stick, forming a fork on which to rest the rifle in firing. The pan is filled with burning pine knots, which being saturated with turpentine, shed a brilliant and constant light all round, shining into the eyes of any deer that may come in that direction and making them look like two balls of fire. The effect is most curious to those unaccustomed to it, and surprised me very much the first time that a deer came and stared at my light. I drew up ny rifle, aimed as mell as I was able, for I could but imperfectly trace the line of my sight, although marked with chalk (a plan we adopt when shooting wild ducks by night in England), and fired, but my inquisitive buck bounded off unscathed, as did another at which I had a tolerably fair shot also that night.

My friend, howrever, baggred one, whereupon we halted, and having lighted our fire in a nice spot surrounded 
by giant trees, sat down by the side of it, and, lulled by its cheerful crackling, alternately dozed and chatted till I forgot my disappointment at failing in pan-hunting, and composed myself to sleep. My companion, however, having killed his deer, was in great spirits and talkative; so finding it quite impossible to baulk his communicative humour, I roused myself by filling and lighting my pipe, and made up my mind to listen. "Well, now ; I vow," said he, "this pan-hunting is an almighty dangerous sort of thing, only to think on what happened the major about this time two years." (My readers must know that the major in question had that morning breakfasted with us.) "It's not forgotten yet; we rile him still about it." "Well," I replied, "I remember you alluded to something this morning which had happened to him that seemed to me to amuse you much more than it amused the major." "Amused him!" he exclaimed, "well, now, I'll tell you the whole perticklers, and if you think it ought to have amused him I'll eat my hat, and that's a fact. Well, now ; here goes. About this time two years the major takes it into his head to go out pan-hunting; now, he never was at no time anything of a hunter, in no-ways: but away he goes one dark night, and as soon as he sees glaring before him the eyes of a fine tarnation big buck, he draws his bead (anglicé sight of rifle) upon him, and downs him. Up gets another, and off a little way. ' That must be the doe,' thinks the major, so he loads up, and away he goes after her, and soon comes up facing her again : crack goes his rifle again, and he downs her too. Well; he thought he had played this time, so he makes his way home, fixes himself a stiff drink, and into bed, and in the morning starts a couple of niggers with an old horse to bring home the meat: but, behold you! no tidings of the deer, so he goes off himself; and when he got to the 
place, Holy Moses ! what should he see, stark and stiff before him, but his beautiful brood mare plummed right between the eyes, and about twenty steps further the foal, too, dead enough this time, and no mistake."

Soon after the completion of my friend's story, morning dawned-Sunday morning! None can so well appreciate "the breezy call of incense-breathing morn" as those who have felt the bracing influence of a fine night's sleep in the forests of the West. The blue robin flutters among the boughs; the mocking-bird ridicules the jay's cry of disappointment at the still unripe fruit; the woodpecker hammers for his food on the hollow trunks of the decrepit giants of the forest; earth and air are again full of life.

The rich vegetation in this hot climate, and its rapid decomposition and reproduction, give birth to a vast quantity of insect life, for the consumption of which nature has provided great numbers of the different species of woodpecker. This bird is furnished not only with a formidably long bill, but with a tongue which he can protrude considerably beyond the extremity of it, and which is armed with barbs enabling him to reach and spear the insect at once in the decayed rood between the clefts of the bark. If he cannot, he taps away on the hollow part, making a sufficient concussion to detach his prey from the bark inside and cause it to roll down into some cavity or place where he can secure it; for, unassisted by his wings, he has the power of running all over the stems of the trees which form his hunting-grounds. In addition to this faculty, he is enabled to maintain a stationary position by forcing the stiff feathers with which his tail is provided against the inequalities in the bark: besides this, he is further assisted by the backward growth of two of his claws. The finest specimen of these birds is the ivory-bill woodpecker, whose operations I have often watched 
with much interest and amusement. By sticking his bill on different portions along the stem of the tree, he seems, by the sound, to discover where a hollow exists, and the moment he is satisfied of having found a valuable place, like an accomplished little woodsman, the bird drives his porrerful bill, causing the chips to fly, till he has succeeded in hewing his way into a luxurious colony of insects.

We secured our horses at sunrise, packed our solitary deer, and returned to breakfast. All the household we found busily engaged in making the necessary arrangements to receive the preacher, a most excellent, humble man, who undertook four different districts of the country, visiting each place alternately once a month. I was surprised at the number of our little congregation, many of whom had come from some distance to attend. The discourse was both instructive and void of pretension, commencing and terminating with prayers, partly from the Church of England Liturgy and partly extempore. When it was concluded, we all sat down to dinner. At each side of me was a fine blooming Arkansas lass, who had ridden twenty-four miles through the woods to this primitive, but sincere, service.

The afternoon of the day following I occupied in cleaning my rifle and splicing the handle of my firepan, and at night started off again with my kind host to make a fresh attempt at this, to me, novel and amusing way of hunting. We proceeded on foot to a favourite lick for stags; for, strange to say, there are some licks to which stags only repair, and where a doe is seldom or never found. Near this we halted, and collected, and with our little axe dressed up the pine knots for our hunting-pans, besides a spare supply which we kept at ow rendezvous. The night was most favourable, being pitch-dark, and after creeping about for some time, I beheld, from the light thrown from my 
pan, a pair of shining balls of fire moving up and down a short distance off. At first I took them for fireflies; but, on more attentive observation, I saw, by their simultaneous motion, that they must be the eyes of a deer. After groping a little farther in that direction, the eyes again appeared; and as they began to approach, the distance between them seemed gradually to increase, like the lamps of a travelling-carriage to a spectator watching its progress towards him, till the animal came so near that I could trace his outline; so, holding my pan steadily on my shoulder with the left hand, I raised my rifle with the right, the barrel resting in the notch before mentioned, and suspecting, that, at night, from not being able to determine the hind sight, one is apt to shoot high in catching the front one clearly, I aimed so low that I could hardly, from force of habit, persuade myself to pull the trigger. When I fired, the deer gave a convulsive bound into the shades of night, and I thought he was lost. Presently, another came; and as soon as he approached within about thirty paces, as well as I could judge by the appearance of the eyes (for I could not see his outline), he began to snort and whistle, "Wheeoo, whoo," which indicated plainly three things to me:-First, that the deer I had just fired at was struck and bleeding. Secondly, that this one smelt the blood. Thirdly, that there was, therefore, no chance of my getting a nearer shot, and that I had very little time to lose if I intended to fire at all. I therefore drew up my rifle, aimed a foot under the eyes, and pulled the trigger. All was silent: the eyes had disappeared. I listened eagerly, but heard nothing, loaded again, and waited a long time. Then I heard Thibault fire; the wounded buck ran in the direction of a pool of water, in which I soon heard him kicking and splashing. I put down my pan, and rushed to the place, and my friend coming up at the same time, wc 
secured him, and drew him away by a circuitous route out of the neighbourhood.

I had resumed my hunting-pan and rifle, and was leaning against a tree, when, like some phantom, the faint dusky outline of an enormous stag walked noiselessly up, and was actually passing me. It made me, from the high state of excitement in which I then was, almost superstitious enough to fancy him the departed shade of an ancient denizen of these primeval forests. I fired rapidly as he passed in front of me. On receiving the ball, he rushed violently off; but from the way in which I heard him thrash the bushes, I knew I had a good chance of finding him at daybreak. I had hardly loaded again, when three or four pairs of glowing eyes presented themselves, glancing about in several directions. I fired a chance shot at one, which fortunately brought the animal down on his tracks: hearing him struggling on the ground, I feared, by the sound, that he was not for one moment safe; I then threw down rifle and pan, and rushed up knife in hand. It was fortunate that I did so, for the stag was recovering, and just as I had seized him with my left hand by one of his horns, which being then only in the velvet, it broke in my grasp, so that. I was compelled to drop my knife, and hold on to him with both hands, holloaing loudly for assistance, till the animal tore the front and sleeve of my shirt with his fore-feet, and made such a powerful fight, that had it not been for 'Thibault, who came up, attracted by my shouts, and stabbed him through the heart, I should not only have lost my stag, but have got the worst of it into the bargain.

I do not think I ever longed so much for daybreak, being all this time in suspense as to the result of my first three shots; but morning beamed at last, when, guided by the blood, we immediately commenced our search. I found the first buck I had fired at struck 
behind the fore-shoulder; he had run about forty yards from where he had received the ball, and was lying dead. The second had fallen upon the spot, the bullet having passed through his head. Thibault found the third,and a most splendid animal he was, - the largest buck, we both agreed, we had ever seen. I have shot a great many since then, but never one of so great a size. Altogether, we numbered five capital fat bucks, one trro years old, one three years old, two four years old, and one colossal old patriarch, whose head, however, was no use for my collection, his horns, at this time of year, being mere soft excrescences.

We had hard work to skin and cut up our game before the flies came to torment us; when just as we had finished, a friend rode down to the scene of action, leading a couple of spare horses for us. So we jogged off home in high spirits to a late breakfast, at a little after eight, and after stretching and nailing up our deer-skins, and canvassing our night's adventures, James Keatts, who was sufficiently recovered to move back to his plantation, and I took leave of our kind host and hunting companion, and departed in different directions; I carrying, as trophies of the hunt, seventeen prime skins which I carefully saved, July being the best month in the year for buck-leather.

Shortly after I had parted from Keatts, while walking one day through the woods in the neighbourhood of Lake Jefferson looking for deer, I perceived the smell of smoke, which I found proceeding from a fire that had been piled up with green wood, and to leeward of which I saw, with great satisfaction, three fine deer, who had evidently taken up this position to screen themselves from the attacks of the flies which plague them greatly, and cause their heads and ears to be in constant motion. In fact, it is the twitching of the ears of a deer that, nine times out of ten, betrays his locality to the eye 
of an experienced hunter; for the eye, from long practice, acquires a habit of seizing instantly on every object in motion, so as to occupy its utmost attention until it is satisfied as to the cause of the movement. Again, nature has so assimilated the colour of all the creatures of her animated world to those of the surrounding vegetation, that, divested of their distinguishing attribute, motion, it is difficult to detect them. Even among the scanty vegetation in our northern latitudes, our experience testifies in favour of this remarkable provision, by which animals without much means of defence are enabled, in some measure, to evade their many enemies.

Thus, if you go to a mountain in the highlands either of Scotland or other countries (for there is a great similarity in all highlands, both as regards their animals and vegetation), you will notice a gradation of colours from the base to the summit: at the base and where the ground is dark, the moor-fowl and hares wear the same dark hue, the former so nearly approaching the colour of the ground as not to be discernible unless in motion. Higher up the mountain, if there are vast tracts almost destitute of vegetation, and where the prevailing colour of the rock is blue or grey, there you will find hares of the same hue, commonly called "blue hares." Among some of the sombre cliffs in the mountainous parts of Ireland, black rabbits are found. Further up again, when we ascend the mountains that are capped with never-yielding snow, the hares (of course more seldom met with) are generally pure white. But the most remarkable instance is that of the ptarmigan, which seldom or never quits the snowy peaks. This bird is a species of grouse, to which it is closely allied, and in its habits and appearance the same; it is quite white in winter, while, in summer, when the snow lies in patches, the bird becomes slightly tinged with 
brown and grey. All sportsmen know how difficult it is to discover a partridge, which thus in comparative safety seeks its food, from the ronderful combination of colours in its various brown feathers, which are striped with straw tints, thus completing the similarity in the bird's appearance to the stubble which surrounds it. Neither is the rank and wild regetation of a tropical climate disobedient to this law; enabling the spotted leopard to lie hidden by leaves when crouching along the horizontal bough speckled with lichens and discolorations in the bark, and screening the striped tiger with the similarly vertical reeds of an Indian jungle.

But to return to my narrative: I stalked noiselessly up to the deer, hiding behind the trees, and taking advantage of their heads being turned away to gain a nearer and a nearer tree, till at last, well in shot, I fired at the nearest, which fell unobserved by the others, who merely gave two or three graceful bounds, and, but slightly alarmed by the report of the shot, recommenced feeding at a little distance off. So, having quietly loaded, I crept round, and had effectually, as I fancied, concealed myself behind a good-sized tree, when one of them suddenly turned and stared straight torrards my cover, evidently suspecting something wrong, and trying to make me out. As he stood facing me, I fired, the ball passing through his throat and stretching him lifeless. The third deer did not stop to inspect his fallen comrade, but sprang off at full speed. I was very busy skinning my prizes, when a negro man arrived from Keatts's on horseback, with a double-barrelled gun across his saddle (a most rare article in those parts) and leading another horse for me to ride back to his master's.

I did not, however, fancy returning home that night, so, as I was near the lake, and the sight of "Snowball's scattering-iron" made me feel inclined for a little wildfowl shooting, I determined, though in a very fever-and- 
aguish sort of place, to camp out for the first time alone. Before, however, sending the man back with his horses, I obtained his assistance to collect some wood, light my fire, and pack the meat for my friends, all of which, except some tit-bits for my supper, and the skins, I loaded on the horse that I was to have ridden. I laid an embargo on the double-barrelled gun, and also on a bottle of whiskey that Blackey had with him; and as my own saddle-bags contained some biscuits and salt, besides powder and shot, and, by great good luck, some swandrops, and I had a tin mug fastened to the pummel of my saddle, I considered myself " pretty well fixed off for the night."

I roasted my venison very awkwardly, and cooked some liver and kidney infamously. I remember this circumstance particularly, because it was the first night I had ever camped out solus. It is only when left to our own resources, that we sportsmen of England feel how very little we are in the habit of doing for ourselves, and how helpless we are rendered by all our civilization. Very delightful, though, is that same refinement of sport in England, where you rise in the morning, not too early, and shave with hot water; a substantial breakfast with a cup of delicious cream-softened tea awaits you in the breakfast-room; your guns are as clean as if they had not been used at all the day before; and you take them without the slightest compunction from the hands of that invaluable individual called the gamekeeper, who is to attend you throughout the day, and who tells you not to trouble yourself by carrying too great a weight of shot, as he has a supply with which to replenish your little two-pound Sykes: finally, when the day's shooting is over, it matters little what the contents of the bag may be so far as dinner is concerned; your own or your host's larder is quite independent of your day's contribution, and the excellent dinner awaiting you is not the 
less sumptuous in consequence of the gun not having been held straight, or the birds having been wild. Your fair lot is cast in the lap of England, a clime where running is unnecessary-fatigue is unknown, beyond that wholesome amount of exertion. which is just sufficient to put you in wind and spirits for the merry dance that winds up the evening.

Such thoughts as these were passing through my mind as I sat by my solitary fire, but they presented themselves in much more forcible contrast on subsequent occasions, when I found myself, after an unsuccessful day's hunting, tired, cold, and very hungry in the wild plains of the Rocky Mountains.

On the present occasion, however, being very comfortable and amply provided for, I lit my pipe and mixed myself some grog from the contents of Blackey's whiskey-bottle, and having dramn one of the charges of shot from my double-barrelled gun, and in its place supplied one of swan-drops, I laid it beside me, and had sat smoking and musing for some time, when I perceived a pair of eyes shining very brightly in the firelight a short distance off. I was puzzled, for they seemed too low to be those of a deer; and when I took up my gun they disappeared. Presently, however, I saw them again; and it then occurred to me that they might be those of a wolf, attracted probably by the offal of the deer close by ; so I retreated a little way, leaving' him a free passage, to encourage his nearer approach, stationing myself, at the same time, in a more favourable position for' a shot. By-and-by, I descried the faint outline of some crouching animal stealing towards the place where the offal lay and affording me a fair broadside. I fired, and saw no more of him; but I thought it prudent to wait till daybreak to commence my search, as I did not much like undertaking it alone in the dark; so I contented myself with a slight sketch 
of whiskey-and-water and another pipe, and lay down to sleep. In the morning, I disoovered how fortunate I had been ; for, a short distance off, and stone dead, lay a splendid panther. I was greatly elated by my night's performance; and instead of starting off along the lake as I had intended, I remained to carefully flay off and stretch my panther's skin; which done, I renewed my fire, and cooked and ate a comfortable breakfast. Then, having arranged everything to my satisfaction during my absence, I took the double-barrel and sallied forth for some duck-shooting.

Several species of ducks are to be met with on the lakes and morasses in this part of the country. I was fortunate enough to come across two or three different ones in the course of my morning's sport. One was a specimen of the pin-tail duck, a fine but very shy bird; his plumage shaded with the most beautiful browns intermixed with white. This duck has a remarkable black patch picked out with white on the back of his neck, long black feathers in the tail, while his head is of soft rich brown colour, and exhibits altogether a very handsome appearance. Some wood-ducks also fell to my gun this morning, very handsome fellows, with splendid green plumage and a white stripe reaching from the bill to the eye and beyond it round the neck. They are web-footed, and provided, besides, with tolerably strong claws to enable them to perch on trees. I bagged five or six, but lost several, as I did not dare venture too far into the water, on account of the alligators. Securing all I could reach to my belt, I walked back to camp, and on my way shot a good-sized rattlesnake. I tried to skin him, but the flies forced me to abandon the attempt, from which I was indeed still farther discouraged by my having blown the head to pieces, and so rendered him of little use or crnament to my collection. 
I found my host himself awaiting my return with the horses, greatly delighted at the fall of the panther, as he had been a considerable sufferer from the depredations of similar animals, and I had the pleasure of fighting my battles o'er again as we rode home together to his house.

I will close this chapter by recounting two hunting adventures of my brother Frederick, who, the year previous to my departure for America, had hunted a good deal on the borders of Lake Jefferson, in the Arkansas country. After my return to England, we often talked over our adventures together; so I have determined to chronicle the following for the entertainment of my readers, as nearly as possible in my brother's words :

"One day, when comfortably seated with Jackson and his family, in the neighbourhood of Lake Jefferson, a little nigger come running in, shouting, ' Oh, massa! terrible big alligator; him run at me.' When we got him to speak a little more coherently, it appeared that he had been bathing in the lake, and that an alligator had suddenly rushed at him, and when the boy, who luckily was not in deep water, had escaped by running to land, the brute had actually pursued him for some distance along the shore. We instantly loaded our rifles and started off in quest of the monster, accompanied by the boy, who came as guide. After carefully exploring the bank and reeds, though unsuccessfully, we concealed ourselves, in hopes of seeing him rise to the top of the water when he thought the coast was clear ; but as we waited a long time without any result, we proposed what certainly was a most nefarious project; namely, to make the boy strip off his clothes and start him into the water again as a bait for the alligator. It was some time before we could get the boy to come round to our view of the matter: his objections to our 
plan were very strong, and his master's threats failed completely, as indeed they generally did; for he was the kindest-hearted man in the world to his negroes. At last I coaxed him with a bright new dollar. This inducement prevailed over his fears, and the poor boy began to undress, his eyes all the while reverting alternately from the water to the dollar, and from the dollar to the water. We told him we did not want him to go in so deep as to be obliged to swim. 'By golly, then, me go for dollare ;' and in he walked, but had hardly reached water higher than his knees, when crash went the reeds, and the little fellow cut in towards our place of concealment at an astonishing pace, pursued by the alligator. The savage beast, as before, came right out on the bank, where we nailed him with two capital shots through the head, that effectually checked his career. He struggled violently, but uselessly, to regain his congenial element, and, after two or three furious lashes of his ponderous tail, sullenly expired. The triumph of the boy was complete: had he, like another infant Hercules, strangled the alligator with his own hands, he could not have been more delighted: he yelled out, ' $\mathrm{Me}$ so berry glad,' tumbled head overheels, walked on his hands, and exhibited every symptom of nigger joy.

"Shortly after, a settler on Lake Jefferson hearing of my success, asked me to assist him in attacking a large black bear that had done a great deal of mischief, and destroyed several of his pigs. Jackson had often pursued him, but the brute had always succeeded in dodging his attacks, sometimes beating off the dogs before he could come up to the scratch, at others evading the silent stalker in the high reeds of the forest. As I had never had the good luck to fall in with Bruin, though I had often seen his tracks, I gladly consented, and we lost no time in setting off." 'Here are the 
brute's tracks again,' he exclaimed, as he pointed to some footprints, evidently those of a very large bear, and which he immediately recognized as belonging to his old enemy. 'Look to your caps, and make sure of no snapping,' said he, as he put on a fresh one; 'I guess this lad is not to be trifled with.' On we went on the tiptoe of expectation, until the tracks at last led us into a dense cane-brake, where we could make but slow progress, and had to use the utmost care to avoid making an alarm from the rattling of the canes. Unfortunately, at last, one of us trod upon a horizontal stick, which snapped loudly, and we had the mortification of hearing Bruin start off with a growl and a crash through the canes close ahead, but of course unseen by either of us. It was of no use to pursue; we could only creep slowly on, while he could run like a dog through a field of grass.

"Poor Jackson! how I pitied him: he looked at me, the picture of dismay, with his eyebrows up to the roots of his hair. I consoled him by proposing a new hunt at night, and, after holding a council of war, we decided on adopting the following stratagem:-R. Jackson knew a favourite pass of the bears, from the canebrake to where the pigs were in the habit of feeding in the wood; 'so,' said he, 'we can set my rifle for him, and the old musket that my father took from an Indian, to whom it was given by the Britishers; so now we'll slope home and fix them off, as you say, to-morrow night.

"On reaching his house, I looked up the musket in question, an old George III. Rex ; and what with cleaning, repairing, and setting up the tackle for fixing both it and the rifle, it was late in the afternoon of the next day before we started with our apparatus complete. The rifle we set next to the cane-brake, as we were. after all our work, not quite sure that the old musket would 
go off (time and rust having destroyed almost all the steel facing of the hammer), but we rere determined to try it at all events, after the trouble we had had; so we placed it further towards the wood, having loaded it with five drachms of powder, a ball, and twenty buckshot. All being arranged to our satisfaction, we retired to some distance to await the result.*

"The night was bitterly cold, but we dared not light a fire near our bear's path, and, what was worse, we could not prudently smoke; so, being without that protection, and armed only with our knives, we thought it safest to climb a tree close at hand, out of the way of bears, wolves, and panthers. We sat on a branch till far into the night, hearing no sounds but the cry of the Whip-poor-Will and his widow, the howling of wolves, and the dismal hooting of the owls. At last we began to get very drowsy, and could hardly prevent ourselves from tumbling off our perch, whispering from time to time, 'I fear he's not coming to-night;' or, 'I don't give him up yet,' when snap went the cap of the rifle ! Mutual ejaculations of disgust escaped us, for we fancied our main hopes dashed to the ground; but they were scarcely uttered, when we heard brave old George III.

* I might as well perhaps take this opportunity of initiating my brother-sportsmen into the mysteries of setting a spring-gun, or rather what is termed a spring-gun in Arkansas. The stock of a gun is firmly lashed to a tree and the muzzle to a stake firmly driven into the ground, the gun being adjusted so as to point at right angles to the path the animal is expected to take, and presented at such a distance from the ground, as that, when discharged, it should lodge its contents in the region of the heart. A fine string is then attached to the trigger, and passed round a piece of polished stick behind the trigger, and then passed forward again beyond the path the animal is expected to take. The opposite end of the string is then fastened to a tree at the opposite side from the gun. The string must neither be slack, nor have any strain on it, otherwise the gun will not remain on full cock. When the animal passes, his chest comes against the string across his path, a slight push strains it sufficiently to draw the trigger, and he is a gone coon. 
go off with the most tremendous explosion. We scrambled down instantly, and ran to the scene of action, knife in hand. As the night was very dark, Jackson, knowing the ground better than I did, got there before me, and while endeavouring to follow him, I heard a fearful cry for help, succeeded by a dead silence. I ran up to the spot, and came in for such a scene! the bear lying dead, and Jackson prostrate upon him, paralyzed with fright, caused by his having run against the bear in the dark, and rolled over the carcase, naturally enough fancying the bear a living beast, and himself a dead man. 'My God, are you hurt?' I exclaimed; but found, on raising him up, neither blood nor broken bones: in short-

\section{"'The nuan recover' $d$ of the fright, \\ The bear it was that died.'}

"The old flint musket had done its duty well, and planted bullet and swan-drops just in the mortal place behind the shoulder. Soon afterwards, morning dawned, and we returned to the house well repaid for our night's watching: Our host was greatly elated at our success; but I, who had not suffered the loss of any pigs, felt rather ashamed, I confess, of the share I had taken in the assassination of the previous night." 


\section{CHAPTER III.}

Mammoth Caves.-Stalactite Architecture.-Ancient America.Rambles in the Earth.-Mummy found.-Subterranean Ball.St. Louis Hunting Club.-A good run.-A fat Buck killed.Hospitable Hunters. -Kentucky talked down.-American Fur Company.

I LEFT off hunting in Arkansas with reluctance; but as I knew that an expedition was preparing to start from Independence for the Rocky Mountains, I thought it best to see about getting up the Mississippi again. Finding, however, when I reached St. Louis, that I had still some time to spare, I resolved on an excursion to Louisville, en route for the Mammoth Caves of Kentucky.

Louisville is a very pleasant, flourishing town on the Ohio; and as I had several letters of introduction, I made the acquaintance of some very charming people, and was so fortunate as to find many of them also on the eve of starting for the caves, where the fashionable watering-place and summer residence of the haute colée of Louisville is situated.

Arrived at our destination, I presented my letter of introduction to the great Doctor Cronan, the famous Esculapius and proprietor of the caves, which are directly on, or rather under, his property. Dr. Cronan has built a most extensive and comfortable hotel, comprising all the luxuries of baths, a fine large diningroom, and splendid ball-room, with a gallery at one end for the orchestra, which includes some first-rate German brass-instrument players. The whole range of buildings forms three sides of a square, built of wood, and most invitingly cool and comfortable.

The caves are a few minutes' walk from the hotel. 
You descend to the entrance by a flight of steps, about forty feet deep, at the end of which you are handed a lamp. At first you descend gradually along a wide passage, which soon terminates suddenly in an extensive cavern, so vast that its sides are scarcely visible by the faint light of the lamps with which each visitor is provided. The earth is rugged and broken, and intersected by rivers, two of which are crossed in a small sifif. On our first day's excursion, we followed one range of the ramifications of caverns and passages to the end, where it terminated in solid rock, a distance of more than nine miles underoround. We entered the caves after breakfast, and did not return till eight in the evening, after a subterrancan walk of eighteen or nineteen miles, up and down hill, over shingly mountains, along torrents, and across rivers of subterranean waters; sometimes squeezing our bodies through passages like mere fissures, then suddenly emerging into a vast cavern, similai to our Matlock Cave in Derbyshire; sometimes through a corridor resembling the shaft of a mine; and finally over a range of shingly hills some hundreds of feet in height.

We caught some fish with a landing-net in these rivers, and found them, by a wonderful dispensation of nature, without eyes or any organs adapted to the reception of light. The stalactites in some places present a most fantastic appearance, covering the root and sides of the cave with beautiful and delicate wreaths of flowers, sparkling like alabaster and as white as the driven snow. In one cavern, about 120 feet in length and 60 in width, they descend and connect the roof with the ground, thus forming the cave into a perfect old Gothic church; each pair of the massive natural columns forming at their junction with the roof a complete and beautiful arch.

From the appearance of these stalactites, the Doctor 
told me that opinions had been formed by geologists as to the probable age of the caves, and periods long antecedent to the creation of man have been pronounced to be the date of their formation. It is said that they must now have been in existence 25,000 or 26,000 years. The columns measure, as well as I can remember, about fourteen feet in circumference on the average. I can scarcely venture an opinion upon this subject myself, but certainly the manner in which the Mammoth Caves were formed appears to me to have been due to volcanic agency, by which, in the first instance, cracks or fissures were produced in the crust of the earth, and afterwards sleared and enlarged by the action of water.

Among other objects of interest are still to be seen several remnants of mummies, indicative of a very early state of civilization, and probably of an era long anterior to that of Indian tribes, dependent altogether for subsistence on the resources of hunting. The limits of these notes will not allow of my entering into a discussion on American antiquities, but many, who have studied the subject with much attention, agree in believing America to have been discovered by Europeans centuries before the arrival of Columbus, and testify to the evidently Roman character of remains still apparent in the state of Ohio.

Little doubt exists as to the fact of these caves having been formerly inhabited, as hearths, evidently constructed with a view to contain fires, have been found in many of the passages; but no conjecture can be made as to the period of their construction, save that they exhibit no apparent traces of European connections.

Some time after the discovery of these wonderful caves, an American gentleman of the name of Ward, who, by all accounts, must have been a very courageous and experienced explorer, undertook, with a number of 
men, to trace out one or two of the numerous ramifications; and although they adopted every precaution that prudence could suggest to facilitate the retracing of their steps, such as marking stone flags at the passages by which they should return, with hands pointing and arrows flying towards the direction of the caves' mouth, yet they were very nearly lost, and did not emerge from their rambles in the "Inferno" till long after midnight, most of their lamps having burned out, while many were the apprehensions of their never again beholding the light of day. The account of this exploring expedition strongly reminded me of the warning of Glaucus's daughter to Áneas-

Facilis descensus Averno,

Sed revocare gradum, superasque evadere ad auras,

Hoc opus, hic labor est.

So few traces of the mummies are now left at the places where they were discovered, that although my curiosity was much excited, I could not find sufficient data to compare them with. Egyptian ones; splinters of beech bark and shreds of flax cloth were the only traces I could find; but I read with much interest Mr. Ward's description of a mummy found, which he was allowed to carry away with him, and which I will here transcribe:-

"It is a female about six feet in height, and so perfectly dried as to weigh but twenty pounds when I found it. The hair on the back part of the head is rather short, and of a sandy hue; the top of the head is bald, and the eyes sunk into the head; the nose, or that part which is cartilaginous, is dried down to the bones of the face; the lips are dried away, and discovered a fine set of teeth, white as ivory. The hands and feet are perfect, even to the nails, and very delicate, like those of a young person; but the teeth are worn as much as in a person at the age of fifty." 
Doctor Cronan deplored the loss of this mammy, which was so perfect. Near her were found many curious little objects, totally dissimilar to anything Indian; among which were a carved wooden cup and a little reed whistle.

During my stay a new crevice in the rocks was observed, and, after some perseverance, was made passable, and found to open into a large gallery, in some places of considerable size, in others diminishing in height and width. It extended about five miles, and was terminated by a piece of subterranean water and solid rock.

No species of regetation grows in these caves, nor did I even find any kinds of moss. The temperature is always uniform, uninfluenced by that of the external air, which renders them, consequently, comfortable in winter, and delightfully cool in summer. The air inside is very pure; so much so, that invalids have tried the experiment of remaining for weeks underground, and, notwithstanding the inevitable gloom that must have attended their sojourn in such a dreary abode, have found themselves greatly invigorated, and their appetites much increased. Une gentleman recovered in a most wonderful manner, after a residence of several months in a cottage there, which was pointed out to me.

'The young ladies had, the year before, voted it too hot to dance above-ground, and had actually planned and given a subterranean ball; choosing a very fine cavern, spacious enough, but not too large to admit of its being properly lighted, and having a boarded floor laid down for the occasion. I saw some vestiges of the arrangements still remaining; and my fair friends assured me that as soon as their numbers were a little more augmented by the advancing watering-season, they intended to give another, and were kind enough to press 
me to stay for it. Our evenings during my visit to the cares were truly delightful, and passed away but too rapidly between music, dancing, and moonlight rambles amidst the delightful scenery of that lovely spot. I tore myself away with regret, and returning to Louisville, took boat up to St. Louis.

As soon as I arrived there, I commenced preparations for my Rocky Mountain expedition, and provided myself with everything except horses, which I learned were much better, and more easily procured in the neighbourhood of Independence. Having still two days to spare before the departure of a boat for the latter place, I accepted an invitation from Mr. Cohen, the president of the hunting club at St. Louis, to join their party in an early hunt next morning in the Illinois country, on the opposite side of the river.

At four o'clock, therefore, next morning, and sorely against my will, I was obliged to jump out of bed, to the music of old Mr. Cohen's horn. I dressed with all speed, and on going down found a very fine horse (though rather too fiery a steed to shoot from) waiting for me in the street. I took my double-barrelled gun, which I had repaired and set to rights after its fall from the tree in Arkansas. The rest of the party, about six in number, came dropping in one by one; we rode down the river for some distance, to a ferry, where we crossed, with our horses. The ferry-boat was worked by a pair of horses in the stern, pacing round and round as in a mill, and, working a kind of capstan, so impelled the boat backwards and forwards. Landing on the other side, we found ourselves in the free state of Illinois, and the dogs waiting for us.

Before proceeding very far, we came to a most in. viting country for game-beautiful rich pasturage, broken by wooded glens; affording at once feedingground, shelter, and water for deer. At that season of 
the year, however, the grass is unfortunately so high, that, even when on horseback, it is very difficult to get a fair sight of the deer ; for, as they bound off, it closes so rapidly behind them, as merely to afford a snap shot in their direction.

We put the dogs to in a beautiful glen of birch and scrub-oak, ranging ourselves along the outside of the wood on the high grassy plain, about sixty or eighty yards from one another. Presently we heard them give tongue ; every gun was cocked, and all eyes strained to catch a glimpse of the deer, when an old buck bounded out of the cover at a grand pace; his horns, however, were covered with velvet, for I could see the shreds hanging from them even at the distance I was stationed: Bang! bang! went old Cohen's double-barrelled gun, but the deer bounded on unhurt; then, suddenly turning, ran the gauntlet past two young men, escaping four shots more, and went off uninjured, leaping gracefully into the air now and then, as if in conscious pride of the daring feat he had performed. Whilst we were drawing another cover, similar to the first, several of the party got snap shots at outlying deer; but they likewise escaped. My horse had, unfortunately, such a fear of the gun, that once, when a doe started up near me in the long grass, the brute, anticipating the report of the gun, wheeled right round on his hind-legs, turning my back to the direction in which she was making off, and so lost me my shot.

A bout three-quarters of an hour afterwards, much to my surprise, I heard, as I thought, our dogs giving tongue at a great distance off, and in a totally different direction from that where we were drawing cover. I set off at full speed, and in this particular found my horse's performance fully equal to what his appearance promised, for he took me through the long grass, which nearly switched my eyes out, to the wooded hills on the 
other side of the plain at a clipping pace. As I neared, the baying of the dogs came louder and louder. "Have I a chance of cutting him off?" thought I to myself as I urged on my horse, whose bottom was wonderful. At last the course I was pursuing as most likely to effect my object (which, after all, was a complete chance), led into a wood too thick to allow of anything of a pace on horseback; nevertheless I dashed on, barely slackening speed till absolutely compelled to stop by some fallen trees, when, throwing myself off my horse, whom I left to his own devices, after a short run on foot I was crossed by the stag in full career. I took a snap shot, and struck him in the flank, being blown a little by riding and running. He turned and was soon lost to view. On going to the spot where I had fired at him, I saw some blood, which made me hope that the dogs might still find him; so, drawing my knife, I blazed a couple of trees, and went back to look for my horse, whom I fortunately found with very little trouble. I had scarcely mounted him again before I heard the sound of a horn in the rear, and to the left on the hillsic!, and a shout of, "Who fired that shot?" "I!" I replied; and, on riding up, found, to my astonishment, that I had fallen in with quite another hunting party, and another pack of hounds. I immediately apologized, and hoped I had not spoiled their sport. T'o which the owner of the dogs and the horn replied, "You are most welcome! your deer's here; a very fair buck. I guess you were near missing, though. Only for that one buck-shot through the kidneys you would not have got him. There are one or two in the paunch, but of no account. We had lost him but for you. How was you so lucky as to fix yourself there below, and all ?" I explained the whole matter in very few words ; whereupon they insisted on my staying with them and sharing their corn-cake, cold boiled pork, and whiskey, on the 
plea that I should lose myself in going back to look for my orn party, but in reality to exercise that innate love of hospitality for which all the Americans are so justly celebrated. They even commenced packing the deer upon my horse ; but I would not hear of it, and insisted upon the right of its belonging to the owner of the dogs. We then sat down to a capital lunch, near a running: stream, which afforded us the "cold without" to qualify our whiskey, one of the party good-naturedly offering to accompany me afterwards to the ferry to show me the way, as I had made such a round in the course I had taken in my pursuit of the stag; which he not only did, but also crossed with me. I think, however, I was indebted for the society of my entertaining companion to the bright eyes of a very pretty widow, who presided at a bar on the Missouri side of the water, and to whose bar he insisted on taking me, in order, as he said, to treat me to a particularly fine whiskey cock-tail ; after which I shook hands with him, and rode back to St. Louis, leaving hin to bask in the sunshine of the little widow's tender glances.

I rejoined my hunting companions of the morning at supper, at the planter's house, which was my hotel. They were surprised to hear of my afternoon's adventure, as they fancied I had gone home long before. We spent a noisy evening, towards the termination of which a most singular bet was made. Old Mr. Cohen was universally considered a great talker, so much so, that he even admitted it himself; but this evening a formidable rival appeared against him in the person of a strange character from Kentucky, who fairly met him on his orn ground, and after supper evinced such unceasing powers of conversation, that old $\mathrm{Mr}$. Cohen was unable to get in a word, and was fain to claim a hearing. "Let me speak, let me speak," he gasped several times, but with no avail ; till, at last, the fool's argument was 
resorted to, and a bet made which should talk the longest. An umpire was chosen to determine which of the two loquacious combatants should be the winner; but, as might naturally be supposed, none of us had the patience to sit out the contest, so we went off to bed, leaving a plentiful supply of brandy, sugar, and iced water. Next morning, at a quarter-past five, victory was declared for Missouri, the umpire returning at that hour and finding the Kentucky man fast asleep in his arm-chair, and old Mr. Cohen sitting up close beside him and whispering in his ear.

I started next day up the Missouri river for Independence, where I arrived in less than a week, and met the party with whom I intended to travel across the prairies.

Every year, at the beginning of September, the American Fur Company sends off an expedition to the different trading posts on the banks of the Missouri and Yellow Stone rivers. This caravan is composed of the traders, workmen, artificers, and hunters of the company, who go up to their forts or trading posts according to their engagements with Messrs. Pierre, Chateau, and Cie., of St. Louis, who constitute the branch establishment in that town. The goods conveyed into the Indian territory for the purchase, or rather barter, of furs and skins, are brought up the Missouri from St. Louis in a steamboat once a year. This vessel starts in the early part of May, at the time most fitted to take advantage of the rise in the upper Missouri, caused by the melting of the snows on the Indian plains and the Rocky Mountains; and, after depositing the various articles and wares for barter with which it supplies the trading posts, terminates its voyage at Fort Union, at the mouth of the Yellow Stone, where that river falls into the great Missouri, arriving thither about the end of July, at which time the Missouri feels 
the maximum accession to its waters. The mouth of the Yellow Stone is upwards of 2,000 miles from St. Louis ; this distance, therefore, is accomplished by the intrepid little steamer, through a most difficult navigation and against a current running six miles an hour, within the space of from seven to eight weeks: the descent occupies about eight or nine days. This steamer carries up all the articles most prized by the North American Indians, with the exception of ardent spirits or any intoxicating liquor. I could hardly detail all the articles brought up for the fur-trade; but the principal ones are guns, powder, lead, coffee, sugar, tobacco, and white, blue, red, and green blankets ; also vermilion, and blue and white glass beads. The articles obtained from the Indians in exchange are chiefly baffalo-robes and the undressed skins of elk, deer, antelope, wolf, with a few of the grisly bear. The rarer and more valuable furs are sought for and purchased for the continental market, by the Hudson's Bay Company, whose territories lie to the northward-the climate of which being so much colder, produces furs of still greater value.

Generally speaking, the colder the climate the more valuable the fur. Even the same animal in the same region will bear a far more valuable fur if the winter reaches a greater intensity of cold than what is ordinary in the districts; so much so, that connoisseurs in furs will talk of the winters of ' 34 and ' 46 , as connoisseurs in wine do of the great vintages of ' 36 and ' 42 . Indeed, my own admiration of beautiful furs is so great, that I cannot help so far participating in their feelings as to think it would be delightful if we could induce our English ladies to take a wider range, and to select from all the valuable furs found in those regions; above all things, to exercise more discrimination in the choice of their so frequently misnamed sables; for it is sad to see a beantiful creature most exquisitely dressed in all other 
respects, but bearing on her graceful shoulder a long strip of painted rubbish, imposed on her, no doubt, as a real sable boa, but to the eye of an observing admirer of handsome furs, as easily distinguishable from this as is a printed calico from a Chinese crêpe shawl.

Why do our ladies adopt the sable (which comparatively is not a valuable fur) to the utter exclusion of the more rare as well as beautiful kinds; such as the black, blue, and silver-grey foxes? If these were but a little more seen and known, I am certain the taste of our countrywomen would no longer allow the Hudson Bay Company to send them to foreign countries in search of purchasers more capable of appreciating them.

\section{CHAPTER IV.}

Old Mr. Kipp. - Preparing for the Start.-Mormons.-Camping at Night.-Duck-shooting.-Gigantic Vegetation.-Prairie on Fire. - Fort Vermilion.-Scalp Dance.-A Dog Feast.-A Woman bought and saved.-Hint from a Bullet.-Fort Pierre.

I LEFT the river steamer at Independence, and made my way over to the farm of Mr. Kipp, a member of the American Fur Company, and leader of the autumn expedition every year into the Indian country of the Upper Missouri, which escort it was my intention to join in the first instance.

Mr. Kipp was a hardy old veteran, who, although upwards of sixty years of age, used every year to ride from his farm, near Independence, up to the mouth of the Yellow Stone river, a distance of 1,500 or 1,600 miles; he had already ridden this journey upwards of twenty times in so many successive years, returning down on the Fur Company's barges or mackinaw boats 
every summer to St. Louis, in charge of the skins and furs obtained by the traders from the Indians.

I arrived in the midst of his preparations for his journey, and obtained his assistance in purchasing horses. This delayed us for one day, so that we did not leave till the 2nd of September, a date which I remember from his observing to me that it was the first time for many years that he had failed in getting under weigh on the first of that month. Our travelling party consisted of about seventeen or eighteen ; namely, old Eipp, the leader; Mr. Murray, a Scotchman in the service of the company, and in charge of Fort Alexander, on the Yellow Stone, the trading post of the Crow Indians, who was also on his way up to that post: we were accompanied by a hardy set of Frenchmen (almost all the employes of the company being French), some of creole and some of Canadian origin-the latter technically termed royageurs-docile, patient, enduring fellows, with constitutions like iron, well practised in journeys of this kind and character. Each man was mounted, and led a second horse packed with his clothes or provisions, or whatever might be wanting on the journey: one of these men was assigned to me to mind my packhorse and carry a spare gun; and I found old Alexandre a most amusing and useful vagabond.

We had grand confusion at starting-kicking horses, obstinate mules, packs slipping off, \&c., with the usual amount of oaths and maledictions; but things fell into working order after a while, and we continued our course without much further disturbance.

For the first two or three days our route lay through a very thinly-inhabited country, with farm-houses at intervals, at which we put up for the night as we went along, and at some of which we found capital quarters, both as regarded board and lodging; of the latter, Mr. Kipp, Mr. Murray, and I availing ourselves, while the 
men camped out. We passed through a good deal of country inclosed and cultivated by the Mormons. I need not hore mention their peculiar tenets in religion, for they are tolerably well known to most of my readers; nor the various enormities of which they are accused; such as holding a plurality of wives, \&ce. At all events, they are an indefatigable set of men, agricultural as well as religious enthusiasts, and the pioneers of a future civilization; for the day is not far distant when, by their means, the Red Man and the buffalo will be swept off the face of the earth. The last spot where we saw white faces was the Council Bluffs, the trading post and the residence of a government agent, where we remained a day supplying ourselves with coffee, sugar, and biscuit, salt pork, and beans, as we did not expect for some time yet to reach a good hunting country.

I will give here a discription of our first night's camp, which will suffice for all, as each night's work was little more than a repetition of the same operations. A little before sunset, we unsaddled and unpacked our horses, placing the packs and saddle of each rider in a separate pile, at equal distances, so as to form a circular inclosure about ten paces in diameter; and after watering and "hobling" the horses, i.e. attaching the fore and hind legs on one side together by means of an iron chain, with a leathern strap round the fetlock, to prevent their straying, we turned them loose to graze; not till then considering ourselves at liberty to attend to our own comforts. Our first business was, then, to cut and gather wood, and to light a fire in the centre of the circle, fetching some water in the kettles, and putting the meat on to cook, and making our beds of saddle-cloths, blankets, and buffalo-robes : this done, we roasted our coffee-berries, and having wrapped them in a piece of deer or buffalo skin, and pounded them on the stump of a tree with the back of a hatchet, put them in our coffee-pot and boiled 
them; and the meat being cooked by the time this process was over, and the coffee made, we fell to with great appetite. After supper, we lighted our pipes, and then each turned in when he felt inclined, and, with his feet to the fire, slept as only travellers in the prairie can sleep. Before day we were up again, unhobled and watered our horses, loaded the packs, and were all in the saddle by sunrise. We rode on till about eleven o'clock, when we camped again for breakfast, letting the horses graze for a couple of hours; at one, starting off again to pursue our march till near dark.

One day we arrived, a little after noon, at a very nice situation for camping, near a lake. Our salt meat was out; we had nothing but beans; and, on account of the Indians having recently scoured the country, we had not met with any heavier game than ducks and teal; so the hunters and I set off to try and get a supply of these; but, to my infinite astonishment, I found that neither of them could shoot on the wing. It was amusing to see how astounded they were at my knocking over a fine mallard, that came wheeling over our heads; they insisted on its being a chance shot, and would not be persuaded of the contrary, until I brought down several successively; and at last, with a most satisfactory right and left, silenced their scepticism completely. They were greatly delighted: "Mais comment diable, monsieur, faites-vous cela?" said one hardy old veteran to me. I offered to instruct him, but could not get him to fire rapidly enough, as he was afraid of wasting his ammunition, which was very expensive. I remember I had to work hard for my ducks that evening; they all fell in the water, and I had to swim for them; but they formed a great addition to the boiled beans we had lately been reduced to.

Next evening we were threatened with rain; and the manner in which we protected ourselves will show how 
ingeniously travellers in the prairies obviate the difficulties which arise. Camping near some willors, we cut of these a sufficient quantity to enable each of us to form a semicircular hut for himself, by bending and sticking the extremities of each osier into the ground, so as to form a succession of arches; after which, by weaving in a fer pliant sallies along the top and sides of this framework, we made it sufficiently firm to support spare skins, saddle-cloths, and buffalo-robes, under the shelter of which we crept in and made our beds.

The vegetation in this part of the prairie was very rank, and in some places gigantic, the grass growing orer thousands of acres from five to eight feet high. For two days we travelled through this, without intermission, occasionally meeting with willows and small spots of timber. Everything around-the huge coarse grass- - weeds that I never saw before, rank and tangled in their unchecked growth-and the cternal illimitable sweep of the undulating prairie, impressed on me a sense of vastness quite overwhelming.

One afternoon, on a day when we had made an early camp, I started with a hunter, to see if we could find anything to eat with our boiled beans. We had to wade along through the grass to a range of hills, about a mile and a half out of the direction of our journey, our progress being rendered still more tedious and fatiguing by the old fallen timber-trees, six or seven feet in diameter, over the trunks of which we had to make our way, as they lay about in hundreds across our path, overthrown by age and tempests. I know not when I have felt so forcibly conscious of my own insignificance, as when struggling through this immense waste, and feeling as though I were suddenly carried backward into some remote and long-past age, and as though I were encroaching on the territories of the mammoth and the mastodon. Nor was my astonishment the less, when at 
length we attained the hills, to meet with a succession of deep dry watercourses, with oaks of enormous size growing along them, and so close against the steep sides, that their topmost branches lay on the bank, overlapping the grassy plain.

I soon, however, abandoned my reverie, and kept a sharp look out, for we began to see signs of game; and, after a while, were pretty well rewarded for our trouble and fatigue, by killing a deer apiece, a turkey, and a blue-winged teal ; but we were dreadfully tired, and but for a bright moon, could never have returned to the party that night. Our arrival was the signal for a second supper, all being eager enough to taste the venison, which, to men who had lived so long upon beans, was a great treat.

One night we were considerably alarmed at seeing to windward of us a lurid glare of red light, by which we soon knew that the prairie was on fire. We instantly started up and kindled the grass between our position and the approaching conflagration, so as to burn away the intervening material, and cut off the progress of the flames by depriving them of food, carefully extinguishing our own fire at the same time, of course. It was a splendid and terrible sight! The fire did not, in fact, come within several miles of where we stood, but at night it always appears much nearer and the danger more imminent than is really the case. Conjecture was rife among my more experienced fellow-travellers as to its cause, but all agreed in arguing no good from it. "Ah, Monsieur!" said one old fellow to me, "les peaux rouges sont en chemin." He Ineant the Indians, and the next day proved him to be right, for on reaching Fort Vermilion (the second trading post of the Fur Company on the Missouri) about noon, we saw, to our surprise, from the hills commanding a view of the plain skirting the river by the fort, the lodges or tents of the 
Sioux Indians and some wild creatures, indistinctly visible in the distance, running to and fro on foot and on horseback.

I never, in all my experience of life in the prairies, witnessed the awful wonders of a prairie on fire; but a brother-sportsman of mine, who was very near losing both horses and mules from a frightful event of the kind, gave me the following description of his experience of one, shortly after my return, which I here transcribe :- "We had seen, during the latter part of our day's journey, a remarkable appearance in the eastern horizon; and during supper observed a smell of burning, and a few light cinders fell about the camp, and presently we remarked that the luminous appearance in the east had very much augmented. There being a little hill in front of us, we could not see distinctly what caused it; but having consulted together, we agreed that it proceeded from a prairie on fire, which, however, was a long way off. About eight o'clock the smell of burning and the glare having materially increased, we walked up to the top of the hill, when a spectacle presented itself to us the most grand that can well be conceived. The whole horizon, from north to south, was one wall of fire, blazing up in some places to a great height, at others merely smouldering in the grass. It was, however, at least, eight miles off; but the wind seemed to set in our direction, so we instantly returned, and took measures to preserve the camp. We were in a corner, as it were, on the bank of the stream, with a good deal of brushwood running up on our left, and the ground sloping up gradually from the creek to the top of the hill. Our guides, on looking at the fire, said that it would not harm us- Ce n'est rien-le vent change.' In short, they would do nothing. In about twenty minutes, however, it approached so near, that there was mo time to be lost, and all hands were immediately em- 
ployed in burning a road across the face of the hill, so as to stop the fire at that part. A more picturesque scene could hardly be imagined. The night was very dark, but as far as the eye could reach, all across the horizon, about four miles in front of us, was a broad, bright, lurid glare of fire, with a thick canopy of smoke hanging over it, whose fantastic wreaths, as they curled in the breeze, were tinged with the red reflection of the flames. Even at that distance we could hear the crackling and rushing of the fire, which, as it advanced, caused a strong wind, and every now and then a brighter flame would shoot high up into the black cloud of smoke over the top of the hill, illuminating for an instant our tents and waggons in the dark hollow, and giving a momentary glimpse of the horses which were picketed on the side of the rise, on the crest of which the figures of the men engaged in lighting the opposition fire (which, as it became too extended, they beat down with blankets, only suffering it to burn a space about twelve feet broad, right across the line of the advancing conflagration), stood out in strong relief against the glowing wall of light beyond them; and as they ran about, tossing their arms, and waving the blankets and little torches of lighted grass, they looked in the distance like demons rather than men. We had no time to look at the picturesque, however, for every moment (owing to their previous obstinacy in neglecting to take precautions in time) became more pregnant with danger, and by the time they had burned as much as would only about half cover the camp, the fire was raging in the bottom at the other side of the hill. I ran up for an instant to the top, and shall never forget the scene. Although still half a mile off, the fire seemed close to me, and the heat and smoke were almost intolerable, while the dazzling brightness of the flames made it painful to look at them; they were in 
three lines nearly parallel, the first of which was just below me, burning with a rushing noise, and crackling as it caught the dry grass, that gave, an idea of total destruction which it is impossible to convey, and stretching array over hill and dale for twelve or fourteen miles on each side of me, lighting up the sides of the hills and the little groves of rood far away. The two lines in the rear were not so much connected, and seemed rather licking up any little spots of grass which had escaped at first. Every now and then a prairie hen would flirr past, flying in a wild uncertain manner, as if fear had almost deprived it of the use of its wings; while all the songsters of the grove were wheeling about among the trees, uttering the most expressive cries of alarm, and the melancholy hooting of several owls, and wailing yells of the wolves, together with the shouts and cries of the men, almost dromned occasionally by the roaring of the flames, added to the savage grandeur of the scene, and one could have fancied the end of all things tras at hand. On returning to the camp, I found all hands cutting the lassoes and halters of the mules, some of which galloped off instantly into the river, where they remained standing till the hurricane of flame had passed over; the others, seemingly trusting themselves instinctively more to man than to their own energies in such an emergency, followed us up the space which me had burned, and remained quietly there, trembling indeed, but without an effort to escape. By the time the animals were collected in this spot, the fire was blazing on the top of the hill, and we all rushed amay with blankets to arrest its progress, if possible, at the part which we had left unguarded; all our efforts would have been in vain, however, and our tents and everything else must have been consumed, but that, just at that weak point, the grass suddenly became thin and scanty, with much stony ground, and we bad the satis- 
faction of seeing the flames stopped there and turned off to the northward along the edge of the brushwood. It was really terrific to be, as we were, trying to break it down in the very middle of the blaze (which, after all, was so narrow that where the flames were not high, you could jump across it); we were, indeed, nearly suffocated by the smoke and heat. As soon as we perceived the fire turned off, we returned to the camp and horses, and all danger was over; but the sight of the three lines of fire stretching up the rising grounds behind the camp, just like the advance of vast army, was magnificent; and it was still more extraordinary to watch the manner in which the fire passed itself on, as it were, over the tops of the highest trees, to the height of at least forty or fifty feet. The whole scene lasted altogether about two hours, and nothing could be conceived more awfully grand. The extraordinary rushing and crackling sound of the flames was one of the most terrific parts of it, and when one considers that the grass is nowhere more than five or six feet high, it is difficult to imagine thow the flame blazes up to such a vast height as it did. The contrast presented, two hours afterwards, was most striking. Instead of the brilliant glare of the fire, and lurid appearance of the sky, there reigned an impenetrable darkness, earth and sky being alike shrouded in a black gloom, which could almost be felt; not a star was to be seen, and the air retained a suffocating, sulphureous smell, as if Satan himself had passed over the earth. We could not distinguish objects at ten paces' distance, and were right glad when a fresh breeze came gently breathing over the prairie, dissipating the murky vapours still hanging in the atmosphere; and a fine starlit sky, with a sharpish frost, at length relieved us from the close, choking feeling we had experienced for hours before. This prairie fire had travelled at the rate of five miles an hour, bringing with 
it a strong gale of wind; for, otherwise, the night was quite calm, both before and after it had passed over."

As we descended the hills, we crossed a large extent of plain approaching Fort Vermilion, which we found surrounded by the Indian camp. The fort itself was a very miserable little place, tenanted by a few sickly whites, servants of the American Fur Company. The surrounding Indian camp consisted of a band of 600 Sioux, including men, women, and children.

An Indian camp is a very striking sight, particularly in fine weather, when the warriors have returned from a successful foray, or expedition, laden with spoils and trophies. In this instance the braves had just come back after an excursion against the Ottoe Indians, a tribe living to the S.E., whom it seems they surprised, and of whom they slew a considerable number. One poor fellow, from the description they gave me through the interpreter, must have made a desperate resistance, mortally wounding one Sioux and severely injuring two others, before he was overpowered by numbers.

Below and behind the fort were ranged the Indian lodges or tents, made of dressed skins of the buffalo, cut and sern together in such a manner as to form, when raised on the poles, a sort of cone, but open at the top to allow the smoke to escape. The inmates were all out, arrayed in all their finery, to celebrate the occasion, and I witnessed the grand scalp-dance which took place round the scalp of the poor Ottoe, elevated on a high pole in the midst. The men were dressed in full costume, with feathers and faces painted either black or red: the women in red or blue blankets, with their beads, necklaces, and embroidered gaiters. The dance was certainly a most characteristic and novel sight. They form a circle round the pole on which the scalp is mounted aloft, standing shoulder to shoulder, and placing the feet together so as to touch at the knees and ankles: 
they then hop round in little steps, hardly bending the knees to the measure of the most frantic bellowing; the

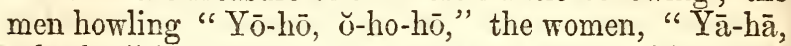
ă-ha-hā," in a horrible monotonous chant, which with children screaming, horses kicking, dogs growling and fighting, and drums beating, formed such a scene of confusion and uproar as baffled description. When the dance was over, I bought the scalp, and also the poor devil's head-dress, made of the scalp of a black bear, for which I gave about fifteen rounds of ammunition and a striped cotton shirt. It is needless for me, however, to enter into a description of Indian manners and customs in this place, as they are already accurately and elaborately detailed in Mr. Catlin's admirable work on this subject.

During the time we halted at the fort, Mr. Kipp, Murray, and I, were invited by the chief to a dog-feast: the meat was really not bad, but at the time it was not pleasant, as I sat eating it, to see the skull of the unfortunate animal, boiled quite bare of flesh, grinning at us from a conspicuous place. However, the time was, not many months afterwards, when I should have been right glad of anything half so good; and even then, it was a not untrelcome change from the dried meat we were eating in the fort. Our host recounted, during the feast, the wondrous achievements of their war-party, whose triumphant rejoicings we had just been witnessing, telling us that among other exploits they had taken a poor woman prisoner, whom they were going to put to death with great solemnity'. We were, however, I'm happy to say, fortunately able to dissuade them from their cruel purpose, and by making a subscription, Messrs. Kipp and Murray on the part of the company, and I, on my own account, bought her from her enemies and set her free at night. I am sure my readers will be glad to know that, as I afterwards learnt, she got 
safely home to her husband and children, who had luckily escaped the massacre. She ran all night, and lay concealed during the day, and guiding her course by the stars, regained her own tribe at the end of two days and two nights, half-starved, but very happy.

Next morning, on rising, we found three of our best horses stolen; fortunately, however, they were none of mine, which was the more lucky as I had but three, and none therefore to spare. In the night the Indians had rooted up the pickets of the fort in front of the horses' heads behind the stable, got themselves in and the horses out. "Well, well ; goodness gracious me !" exclaimed poor old Mr. Kipp on seeing how an entrance had been effected. I endeavoured to console him by telling him what a proof it was of the uncertainty of human affairs, since on leaving the stables the previous evening he had even taken the precaution of locking the door before the steeds were stolen. We found that it was not the Indians camped around us who were the culprits, but some audacious rascals who had pursued us a long way, and had, no doubt, been unable to carry out their plan before, from our guarding the horses so carefully at night, while out on the prairie. Pursuit of course was useless. In the evening, however, by wonderful good luck, the best of the three horses broke away from his captors, and returned to us of his own accord.

The following day there was a great council of the chiefs, at which they determined to start on the morrow for their autumn hunt. We travelled a couple of days in their company, as they requested us not to move on in advance for fear of frightening the game, if there should be any. Accordingly, the following day order's were given by the chiefs to get under way and take down the lodges.

The whole labour of erecting the lodges or tents in 
the morning and taking them down at night devolved on the women. The poles which support the tents form the carriage on which they are drawn, together with pots, kettles, children, puppies, \&c., by the horses and dogs ; the women being also obliged to harness the dogs and horses, untackle them, water them, and catch them; the men all the time sitting still and looking on.

The moving of the camp was a very pretty and striking scene. Behind the mounted Indians followed those who had no horses; then, in a long row, the horses drawing the lodge poles fastened to a straddle, the other ends trailing on the ground. On these poles is a kind of receptacle for the different cooking-kettles and other property. The dogs are harnessed in like manner, and horses and dogs keep an unbroken line, together with their attendant women, who have very severe tasks to perform. Our day's journey was not very long: the men rode in every direction, looking out for buffalo; but as yet without success. Next day a halt was ordered at about ten o'clock by the chiefs, who gave strict orders that no inmate of the camp should proceed beyond a certain distance, and that all dogs straying out of bounds were to be shot. The young men went out again after buffalo. My horses were tired, having come such a long journey, and as I did not expect to meet with much game I determined to let them rest, and set off alone with my double-barrelled. gun to look for ducks along a little creek, near which we were camped.

I had not gone above a quarter of a mile when I was suddenly startled by the report of a gun just behind me, and a bullet whizzed close past my ear. I turned quickly round, and saw an Indian lower his gun, having fired at and missed me. I easily came up with him as he was attempting to load, and completely cowed him. by holding the muzzle of my gun to his face, with both 
barrels cocked, making him knock under in very quick style. An old Indian, who fortunately happened to be near, and seeing things were taking a serious turn between us, came up, and by signs explained the matter. The fact was that I had not understood the proclamation of the morning, and had unintentionally transgressed it, and this was their way of letting me know it. It all, however, terminated very well, and most fortunately for me, to whom the consequences might have been fatal, and I took the precaution of getting the old fellow who had acted as mediator between us to accompany me for the rest of the day under pretence of picking up the ducks. I found him quite invaluable as a retriever, for he recovered several birds that I should otherwise have given up for lost. One duck, in particular, late in the evening, fell under a bank; when I got tired of searching for it, the old Sioux would not give it up, and after three-quarters of an hour's rading above his knees in water, pulled it out, much to his own satisfaction and my surprise, from under the opposite side of the river.

No buffalo had been seen when we arrived in camp that night. Mr. Kipp, Murray, and I, had quite a laugh at the Indians as we plucked and boiled the small game I had brought in. I did not fail, however, to call my old retriever, and make him sit down and share, on which he exclaimed "How !" and seemed much delighted.

On the morrow our troublesome companions the Indians took a more southerly direction, leaving us to go our own way, which we were not sorry to do. We continued travelling all that day and part of the next, when we came in sight of two or three Indian lodges. On going up we found that one of them belonged to an Indian whom old Mr. Kipp knew, and whom he had formerly seen at Fort Pierre. He invited us into his 
tent to eat buffalo, saying that he had made a good hunt and had fat meat in his lodge ; and, there, for the first time in my life, I tasted buffalo meat. To say what I think of its flavour and its excellence would be but to repeat all the encomiums upon it that I have ever heard or read. It is decidedly the best meat I ever tasted, and I have eaten as great a variety as most people. The fat is peculiarly delicious, and more like that of turtle than beef, over which it has a decided superiority in delicacy of flavour, and in not surfeiting those who even feast immoderately upon it.

We took leave of our hospitable Indian, and travelled onwards until we reached an island in the Missouri, where the A. F. C.* tried to establish a farm, for which the site was thought peculiarly favourable, the river forming such a complete substitute for a fence, on all sides. The project succeeded for awhile, but the predatory disposition of those most incorrigible, untameable thieves of red-skins, soon broke out. They killed the cattle, burned the hay, and stole the corn when ripe, and actually had the impudence to offer it for sale to the F.C. traders, who "O tempora! O mores!" bought it back from them at a blanket or 100 rounds of ammunition a bushel.

Shortly afterwards we came opposite Fort Pierre, built on the other (i.e. south) side of the river. We fired some shots as a signal, on which they sent boats to take us ari? our horses across; and we were by no means sorry to find ourselves comfortably installed in time for breakfast in the finest of the Fur Company's Stations on the Missouri. In fact, Pierre is the largest fort belonging' to the F. C.'s traders. It consists of a large space about 120 yards square, inclosed by piles of timber 24 feet high, driven well into the ground. The 
roofs of the store and trading houses are attached to two of the sides, with the stables, straw-yards, carpenters' and blacksmiths' shops, and a dairy for such coms as may escape the marauding hands of the Indians. A flagstafi, gaily rigged, stands in the centre of the square, and the whole establishment has a most inviting look to a set of weary travellers on jaded horses, and who, with the exception of the aforesaid buffalo feast, had not fared over well for many days past. Here, therefore, we remained a day or trio to refresh the horses, which were looking miserably worn and thin, and to revel in fresh. meat and new milk for the benefit of our own health. We retailed, of course, all the news from below, which, though stale enough to us, was very acceptable here. Major Drips was in command; had been in his younger days a great leadcr of trapping-parties in the mountains, and was now a sober, steady trader.

\section{CHAPIER V.}

Clear A tmosphere.-See Buffalo.-Arrival at Fort Union. - Buffalohunting.-Winter sets in.-Hunting Party.-Escape from a War Party.-A Race for Life or Death. - Wanton Cruelty of the Sioux.-A heroic old Bull.-Domestic Calves and Bison Bull.

WE left Fort Pierre on the 5th $0{ }^{\prime \prime}$ 6th of October to pursue our journey, and generally found timber to camp in for breakfast at mid-day, and also for supper and sleeping at night, but were much inconvenienced by want of fresh water, which disagreed with old Mr. Kipp and many of the men. We had long entered the high prairies. The atmosphere in these regions is extremely healthy, and its effect upon the constitution something wonderful; so much so, that persons never suffer from 
coughs or colds; the complaint is quite unknown. I have frequently in the morning risen from a sound sleep, under a down-pour of rain, and found my shoulder, on the side I had lain, in a pool of water ; have got up and ridden on, cold and shivering, till the sun rose and his genial rays thoroughly warmed and dried me ; and yet have taken no harm. So clear is the air, that the natural range of sight is greatly extended, and distant objects may be clearly and easily seen, which in these islands, or in the States of America, it would be impossible to recognize or define. It is almost like looking through a telescope.

Another peculiarity is the great difficulty a person unaccustomed to the prairie finds in ascertaining the relative distances of objects, and consequently in estimating their size. I have frequently made, myself, and seen others make, the blunder of mistaking a buffalo bull for a crow, or more frequently a crow for a buffalo bull. My readers may be inclined to smile at this; but I will answer for it, that if any of them have ever stood upon the sea-shore with a sailor, and compared their estimate of distances with his, they will have found a considerable difference, and so it is upon the prairie. The eye ranges over a sea of short waving grass without a single intervening object to afford it the accustomed means of estimating relative size and distance. The appetite in this healthy region is also greatly increased, and I have been told by American physicians that many are the instances where consumption has been completely eradicated from the constitutions of people travelling up into these regions, even under circumstances exposing them to very great hardships.

The difficulty of finding water here secmed rather on the increase, until late one day we saw a herd of antelope, always a sure sign of its not being very far off. 
The next most important thing was to find it, as one of the party observed. "Never mind," said old Mr. Kipp; "leave the horses to themselves, and they will find it." We dropped the reins upon their necks as he directed: one or two of the old stagers pricked up their ears, stood still for a little while, turned aside from the course we rere pursuing, and walked us straight to a beautiful spring. It was the only pure, fine-flavoured water we had enjoyed since leaving Fort Pierre, and we had entirely to thank our poor suffering horses for finding it. We accordingly camped here for the night, but as there was a scarcity of timber, we were obliged to make our fire of dry buffalodung, of which there ras abundance, and which proved a very tolerable substitute when gathered in sufficient quantity.

We were now advanced some considerable distance in the country of the buffalo, but had not as yet met with any. The next day, however, before eleven o'clock, we actually did come in sight of the long-wished-for game. At first the dark grotesque outlines of trro old out-straggling bulls loomed over a rising hill; they remained a moment to contemplate us, and then cantered off at a very leisurely pace, tossing their great heads at every stride. We allowed them to go unmolested, as few of our horses were in condition to follow them, and we were in hopes that, by waiting a little, we might come across some cows, which would prove a much greater prize to us. But we saw no more that day.

On the morrow, Mr. Murray and I observed a bull in a ravine, so we stalked and shot him; but he proved so old, lean, and tough, that we left him to the wolves.

It is almost unnecessary for me to give any description of the buffalo, as both he and his habits must have so often come under the observation of my readers in the writings of travellers and the descriptions of natu- 
ralists. It should, however, be remembered, that the animal commonly called buffalo in America, is the bison. Though not so tall as the large breeds of our cattle, they are larger and deeper in the body; the shoulders and fore-quarters being very heavy, and the hind-quarters very light. The full-gromn bull is immensely shaggy, especially about the head, which is covered with such a rast quantity of fur, wool, and long hair hanging down over his eyes and almost concealing the horns, as to give it the appearance of being onethird the size of the whole body. In the winter month he is covered all over with thick, long, and curly fur; a mane of light-brown hair and fur, like that of a lion, only larger, envelopes his neck; a long glossy black beard hanging from his chin, like a deep fringe, sweeps the ground; which, with his savage-looking muzzle and prominent black eye flashing between the tangled locks of his hair, give him altogether a most ferocious appearance. In reality, however, he is a timid animal, and it is only when he imagines himself unable to escape that he becomes desperate, and therefore dangerous, from his immense strength. Finally, this strangelooking creature is supported on short slender legs, more resembling those of a deer than an $0 x$, and fringed, like his throat, with masses of coarse shining black hair, about a foot long, as far as the knee; his hind legs being so bent under him and so slight, as to give at first sight the impression of weakness, as if overweighted by his huge carcass ; an impression, however, soon effaced when you see him gallopping up a steep hill where no horse could follow; or along a narrow ledge that would scarcely afford footing to a goat. 'The cow is swifter than the bull, and much smaller; she does not calve until fully four years old, nor does the bull breed till nearly that age. In winter, strange to say, they migrate northward, and collect in great numbers 
on the banks of the Missouri, to find shelter in the timber, and browse upon the willows, or coarse grass, still uncovered by snow. Taken altogether, they are 2 curious and interesting animal, and uncommonly good eating.

At three o'clock on the 27th of October we arrived at Fort Union, the termination of our journey, right glad to rest ourselves and our tired horses, who looked miserable enough and scarcely able to survive the winter. Fort Union is situated about three miles westward of the junction of the Missouri and Yellow Stone rivers, and built in a similar style to Fort Pierre. It is in the Assineboine territory, and is the depot of the Fur Company's trade through the Upper Missouri.

Several of the principal Indians came to relcome old Mr. Kipp, who was a great favourite. There were two bands, one of whom had pitched their lodges about thirteen miles below the fort on the river, and the other settled themselves about six miles above the fort to the westward, and all agreed in declaring the buffalo abundant in that part of the country. After a day or troo's rest, therefore, I started off with the hunter of the fort in quest of them. The day was very fine, and we rode each a hack, leading a hunter (or runner). We had not gone more than three or four miles, when we came in sight of a very fine herd of buffalo ranging to the north-east of us. Riding some distance round, in order to avoid giving them the wind, and screened by some hills and broken ground, we approached as near as we could unperceived; then dismounting from our hacks, we tightened the girths of our runners, and mounting them, prepared for the chase. Holding our loaded guns in rest, we started at full speed. Away went the huge mass raising a whirl of dust over the plain, followed by us in hot pursuit. We soon overhauled them, and continued loading and firing away 
into the herd. My companion shot two, but my first attempt was a total failure; however, I was more fortunate the second time, and brought down a fine four-yearold bull.

Buffalo-hunting is a noble sport, the animal being swift enough to give a good horse enough to do to close with him ; wheeling round with such quickness as to baffle both horse and rider for several turns before there is any certainty of bringing him down. Added to which, there is the danger of being charged by one old bull while in pursuit of another; this, however, they will not often do, unless when blown by the awkwardness of a bad hunter, in chasing them too far, when they turn and get desperate.

The first object in approaching a herd of buffalo should be, to get as near as possible before charging them; then, rush in with your horse at full speed, single out one animal, and detach him from the herd, which you will soon do, and after a turn or two be able to get a broadside shot, when you should endeavour to strike him behind the fore-shoulder. While reloading, slacken your horse's speed to a hand gallop. The general method of loading is to empty the charge from the horn slung round your neck into the palm of your hand, whence you can more easily pour it down the barrel; you then take a bullet wet out of your mouth, and throw it down upon the powder; by which means you avoid the necessity of using the ramrod, a most inconvenient process when riding fast on horseback. I found it from experience better to dispense with both powderhorn, ramrod, and copper caps altogether, and use a light self-priming flint gun, carrying the powder loose in the skirt pockets of my shooting-coat, and thereby having no further delay than to thrust my hand in for it and empty it down the barrel of my gun ; accuracy in quantity at such close quarters being of small importance. 
Taking the bullet from the mouth is both the quickest and safest method of loading; quicker than fumbling for it in your pocket, and safer, because its being wet causes it to stick for a moment without rolling forward on depressing the muzzle to take aim ; and my brother sportsmen are doubtless aware of the danger of leaving sin empty space in the barrel between the powder and the ball. I would not, however, recommend any one to depend too much upon the detention of the wet bullet, but to fire immediately on lowering the muzzle. I ought here to mention, that in running buffalo, you never bring: the gun to your shoulder in firing, but present it across the punmel of the saddle, calculating the angle with your eye and steadying yourself momentarily by standing in the stirrups as you take aim. This is difficult to do at first, and requires considerable practice; but the facility once acquired, the ease and unerring steadiness with which you can shoot is most satisfactory, and any one accustomed to this method condemns ever afterward the lifting of a gun to the shoulder whilst riding at speed, as the most awkward and unscientific bungling.

We drew up our horses, and proceeded to skin and cut up the animals, and were soon joined by the drays despatched from the fort for the purpose of taking home the meat. What we had lilled that day was very good and tolerably fat. I have before adverted to the excellence of bison beef, and the superiority of its fat over that of the domestic ox ; but before leaving the subject, I will state two instances in which I myself saw this superiority fully established.

Old Mr. Kipp, at Christmas, thinking to give all-the employés and voyageurs of the Fur Company at Fort Union a great treat, had for some time previously been fattening up a very nice small-boned heifer cow, which was killed in due time, in prime condition. All who 
had been reckoning on the treat this would afford them, sat down in high expectation of the ensuing feast; but after eating a little while in silence, gradually dropped off one by one to the bison meat, which was also on the table, and were finally unanimous in condemning the beef, which they said was good enough, but nothing remarkable, and the fat sickening. A plate-full of it was also given, as ordinary buffalo beef, to an Indian woman in another room at the fort, on the same occasion : she pronounced it good food, but, said she, "it is both coarse and insipid," and the fat, if she were to eat much of it, would make her sick.

I mention these circumstances, having been one of the very few who have seen the comparative merits of the two meats tested by Europeans, Americans, and Indians at the same time, and heard the unanimous verdict in favour of the wild bison.

Not many days after my arrival at Fort Union, winter burst in on the vast region of prairie, bringing all its terrors with it. A snow-storm of three days' duration, accompanied by a strong north-westerly wind, kept us all prisoners in the fort, the river partly froze, leaving but a narrow channel torards the opposite bank. I managed to cross, hotrever, in a boat belonging to the fort, and killed a very fine three-year-old buck, but did not see any elk, which game I was most anxious to meet.

Among the gentlemen at the trading-post, I found a good sportsman and first-rate rifle-shot in my friend Mr. Denig, the accuracy of whose shooting was surprising, even to me, who had had considerable practice. $\mathrm{He}$ was frequently my companion when my excursions did not lead me very far from the fort, where, as physician and interpreter, he was obliged to be in constant attendance. Rabbits and prairie-hens were our principal game on these occasions. We used our rifles only; and while I was content with bringing the birds down any 
way that I best could, my companion, four times out of five, would smash their heads or cut them off altogether. Prairie-hens, although not wild, seldom allow you to approach within fifty yards. They do not mind the report of the rifle, and when a number are on the same tree you may bag most of them by commencing with the lowest, so that his fall from the tree may not alarm his companions. This bird is evidently a species of grouse, and stands as tall, but perhaps not quite so heavy; it is beautifully speckled with two or three greys, orange, white, and brown. In the breeding season the male exhibits two large orange-coloured gills, with which he makes a strange drumming noise, audible at a great distance on the prairie. Its flavour is much affected by what it feeds on, and in this part of the country where its principal food is rosebuds, is not nearly so good as in civilised districts, where it eats Indian corn by wholesale.

So completely were my horses knocked up from the effects of their long journey that they did not recover their condition at all during the winter, and were therefore of little or no use to me at Fort Union. Frequently, however, during my stay at that post, meat was scarce, and on these occasions I obtained a reluctant consent from old Mr. Kipp to ride a very gallant little grey buffalo-runner when I wanted to hunt on horseback. He was a powerful sagacious little animal, and eventually we understood each other thoroughly. An Indian horse is almost entirely guided by the balance of his rider's body; when I leaned, therefore, towards the left on approaching any particular cow, he pertinaciously pursued her, and on my firing used to sheer off in the most dexterous manner, for having once had a rip from a buffalo-horn, he was far too wise to trust himself within reach again.

The best hunters of buffalo are the English half-breeds on the Red River, from Lord Selkirk's settlements ; they 
will in passing a buffalo at full speed hit him mortally behind the shoulder at fifty yards, five times out of six.

A violent snow-storm about Christmas-time nearly put an end to my hunting bufialo on horseback, and a strange epidemic at the same time broke out among the inhabitants of the fort, and spread like wildfre ; a sort of cold that affected the throat like mumps, internally and externally. So many of the men were laid up with it that the remainder could hardly supply the fort with wood for fuel, which they cut from the neighbouring point. Fortunately, however, the invalids began to recover before the healthy ones were taken ill; but at last both the hunters were affected, and the labour of procuring meat for the fort devolved on my friend Mr. Denig and myself. This for a long time we were able to do with great ease, as the buffalo were sure to be found in the timber skirting the river on both sides, so that we could easily stalk them, and, when we had killed one or two, send out people to skin, cut them up, and take them back to the fort in a dray or sledge. Finally, alas! my friend, the physician himself, was laia low with this complaint. He had a name for it, as doctors have for every ailment, whether they know anything about it or not, but that did not much assist him in its cure, for he fared no better than the rest.

I started off one day by myself after a large herd of buffalo, about three miles westward of the fort, adopting the novel expedient of carrying with me a white blanket in order to stalk them. I took such a course as not to give the herd my wind, and with the cover afforded by the timber on the point, succeeded in getting within a couple of linndred yards of them ; I crept forward on my hands and knees, covered by the blanket, which prevented them from distinguishing me amidst the surrounding snow, and enabled me to approach until I came within shot. I continued creeping about and around them, 
singling out the best and fattest of the cows for uprrards of an hour, and it was not until I had laid five of their number low that they smelt a rat, and bolted of unamimously, tossing their shaggy heads and ploughing up the snow.

Being perfectly satisfied with the abundance of meat I had obtained, I proceeded to cut out the tongues, which I fastened with thongs to my belt. Then leaving' my blanket on one animal, my cap stuck on my loadingstick on another, a pocket-handkerchief fluttering from the horns of a third, \&c., to keep off the wolves, I ran off at full speed to the fort, which I entered just as the twelve-o'clock bell was giving the signal for dimner.

We had buffalo and venison that day of my own providing, but dressed with most delicious bear's grease and buffalo marrow by a capital cook. It happened to be Thursday, our pridding day, which will account to my readers for my making such haste home.

Dinner over, I requested old Mr. Kipp to give me a couple of experienced men with a dray, in order to cut up and bring home my buffalo meat, but so numerous were the sufferers from "the mumps," that not one could be spared, and the day was too cold to induce the women to come to my assistance; I returned alone therefore to the ground where my bisons lay, and with tiro packhorses, cndeavoured to bring home as much of the meat as possible. I commenced with the finest one, the robe of which was beautiful, and proceeded to cut her up, though not without a good deal of exertion and repugnance at first. One soon, however, gets over that sort of squeamishness. So slow and awkward, however, were my first attempts at cutting up this heavy game, that night closed around me ere I finished a second buffalo; so that all I could carry away was the skin of the finest, with the ribs, loins, \&rc., of two cows, leaving three fine animals untouched, to be devoured by the wolves, which mortified me exceedingly, especially as it 
was chiefly owing to my awkwardness and want of practice in skinning and dissecting heavy game. It was nightfall ere I arrived with my heavily laden horses at the fort.

In two days all the fresh meat I had brought in that evening was gone, and the buffalo were four or five miles off ; taking my friend the little grey (the especial favourite of the old gentleman's) I stole out with him unperceived, and had a splendid run, flooring a cow, and wounding a buli, which I left for the present, and then stretching away at full speed, I pursued after another uncommonly fine fat cow. She gave me an awful chase, turning and doubling incessantly. My little horse was sorely at a disadvantage in the snow, and began to show symptoms of distress; but I could not manage to get a broadside shot. At last making one more push, I got pretty close behind her, and raising myself in my stirrups, fired down upon her. The effect was grand. She dropped at the report, the bullet breaking her spine. My little horse, unable to stop himself, rolled right over her, making a complete summersault, and sending me, gun and all, flying clean over both of them into a snow-drift. I leaped up, ran back to my horse, which I caught without much difficulty, and was glad to find no more hurt than myself. My gun was filled with snow, of course, but otherwise uninjured. I certainly was in luck that day, for the guard of the horses at the fort joined me soon afterwards; he had seen the buffalo running, and came to my assistance to secure and pack the meat, so that I was enabled to get home and put my gallant little grey quietly into his stable again.

The weather now became intensely cold, and a fierce northerly wind, accompanied by a good deal of snow, again kept us all for some time prisoners in the Fort. We led a very routine sort of life while our durance lasted. We rose when the bell rang, and repaired to the 


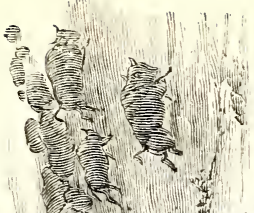

(1)
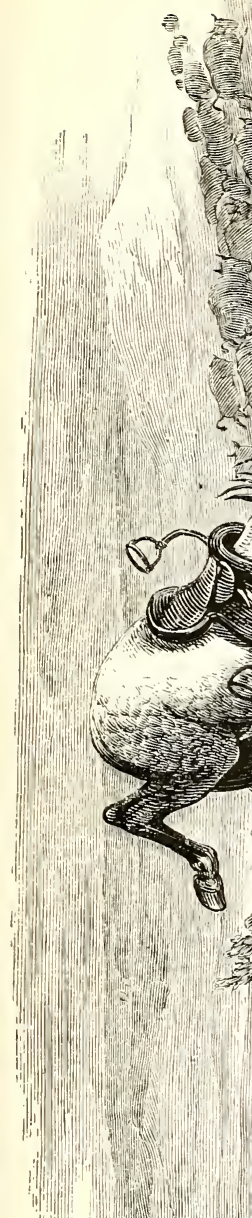

$+7$ 舟
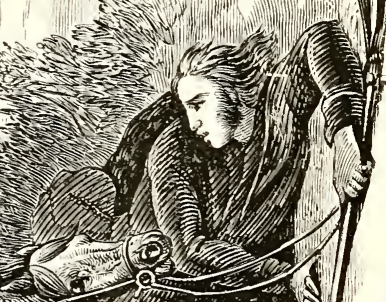

dining-room and a cheerful cotton-wood fire; shortly afterwards our mulatto cook served breakfast, consisting of fried buffalo and venison, round breakfast-cakes of wheaten flour (a supply of which is brought up every year by the steamer), and excellent coffee, with the luxuries of cream and butter. At twelve we had a dinner very similar to breakfast, with the exception of coffee, which we drank again at supper.

We rere occasionally favoured with visits by the Indians, from the upper and lower camps, who came sometimes from motives of curiosity, sometimes to beg tobacco, sugar, a knife, vermilion, or some such trifle; and assisted to pass away the time by accounts of their war-parties and exploits. I heard some astonishing: stories of the daring adventures and hair-breadth escapes of some of the hardy hunters and trappers of the prairie - a race now rapidly becoming extinct, owing: to the great fall in the price of beaver, from the recent introduction of silk into the manufacture of hats. These veterans of the prairie, so admirably described in Mr. Ruxton's book (the best collection of trapper stories I ever came across), are subject to constant vicissitudes of wealth and poverty, starvation and plenty, and have continual intercourse with the forts or trading-posts throughout the Indian country, to exchange their furs for ammunition, beaver-traps, a saddle, or sometimes even a horse, if they have sufficient equivalents to purchase so expensive an article in that country.

On some occasion of this sort, old Williams made his appearance at the fort, to the astonishment of all, who had supposed him dead a long while before, as he had been one of a party surprised by the mountain Blackfoot Indians; but, as it afterwards appeared, had made his escape, he being the only survivor. After mutual congratulations, Mr. Denig asked him to recount his adventure, which he did in a most interesting: and solemn 
way. He and several other trappers had been hunting for beaver on one of the tributaries of the Yellow Stone, or Platte, I forget which now, and after their day's toil had camped in supposed security, with the horses in their neighbourhood, and were lying by their fire after supper, soundly wrapped in that sleep from which they were to rise no more, when Williams dreamed: "God Almighty appeared to me," said he, slowly and solemnly, "in flames and sparkling flashes of fire, and said, "Williams, you have been a very wicked man; I hare saved your life very often, and you have not profited by it; but I will save you once more." " Bang, bang, bang" went the guns of an Indian war-party, close by; and most of his companions rolled from the sleep of time into eternity, or, on rising to flee from the danger, were immediately massacred. Williams, however, clubbing his rifle in one hand, and grasping his knife in the other, rushed right at the spot from which the shots were fired, and consequently broke through the enemy, and got clear off ; for those that had fired were but few; the larger number of the savages being ranged at the opposite side, in order more effectually to destroy the whole party, by intercepting them as they fled from the obvious danger. "Well, Williams," said Mr. Denig, after a pause, "and is it a warning you have profited by ?" "Well," replied the old fellow, "I don't know ; I've worked very hard at my traps, and paid all my debts; I've given up swearing, and that sort o' thing; and if I knew anything else, I'd do it." Most likely the sleeping hunter was inspired with this vision in a moment of time at the instant dawn of returning consciousness, when arakened by the explosion of the firearms which had sugrgested the dream.

Our snow-storm lasted about three days, and was succeeded by cold, brilliant sunny weather. 'The chief of the upper camp and his brother sent an old Indian with 
a message to me, and an offer to accompany me for one or trro days' hunting on the Yellow Stone. Accordingly we started next day, joined by one of the hunters of the fort and two boys about sixteen or seventeen years of age, who came for the purpose of assisting us in skinning, cutting up, and packing the meat. After crossing the Missouri a little below the fort, and proceeding some way up the Yellow Stone, we came in sight of a splendid band of upwards of 100 elk. Never shall I forget the grand and imposing appearance they presented. Like a regiment of cavalry they passed along the plain, the old stags, with wide branching antlers, leading the van. We immediately left our horses with the old man and boys, and crossing the ice, the chief and the hunter took the left side of the river, and his brother and I the right. We got several shots, and succeeded, after a good deal of running and hard work, in bagging three of them. Ramsay, the hunter, and the chief, fired several shots, whereupon the elk rushed to our side of the river, and I got a shot at a noble stag, bearing a splendid pair of antlers. I struck him behind the fore-shoulder, upon which he started and rushed forward, crashing through the willows at a great pace. We pursued as fast as we could make our way through the snow, and, after a long, hard run, two more shots brought him down; he made one final effort to escape, and fell struggling on the snow, where he soon expired. I was greatly pleased at my success, but so utterly blown, that I threw myself forward with my elbows on the ground, to assist my efforts to breathe ; but, by following the Indian's example, and eating a handful of snow, I was soon relicved. I now thought I had ample leisure to examine my noble elk, which measured five feet three inches in height from the top of the shoulder, and uprards of six and a half feet round the body ; but the Indian would not allow me to stay, pointing forward and saying, "Cooa, coona" (come, 
friend). So we set off again; and before evening closed, he shot a deer, which we skinned, cut up, and hung in a tree. Covering it with the skin, we left it till next morning, as it was rather too far for the boys to go for it that night. This done, we ran back at a jog-trot to camp, and on our way overtook the boys with the meat of my elk, cut up and covered with its hide, all safely packed on the back of the horse they, were leading.

As we approached, we were cheered by the red glare of the fire flickering through the willows, and shedding warm tints on the leafless frozen trees. The snow around the fire was partly scraped away, forming a sheltering wall behind our backs as we sat. Elk-meat, spitted on short sticks, with the sharpened end stuck in the ground, was roasting in all directions. Ramsay and the chief had killed two elks, a stag and doe, and wounded several others, which they did not get. The herd had got perfectly terrified at the firing on both sides, and kept trotting backwards and forwards, literally panic-struck ; so much so, that had they shot only tolerably well, they must have killed many more, as they actually fired eleven times between them. Indians, in general, shoot very badly, and in their pursuit of game depend most on their skill, craft, and patience in approaching, and also on their wonderful powers of running. I found the elk good, solid, wholesome meat, very like our beef; but the fat is disagreeable to eat: it is white and hard, getting cold, as it were, immediately in the mouth.

On putting my hand in my pouch, after supper, I found that I had lost my pipe, which, when the old man understood from Ramsay, who interpreted for me, he asked, "Where?" I said I did not know, but that I supposed it must have been at the place where I dismounted. Upon which he said, "We will go and find 
it," and to my surprise got up, took a burning piece of wood from the fire, and led the way. After poking along for about 100 yards he stopped, stooped down, and searching for a little while, pointed out to me with a modest self-satisfied chuckle, the short white clay pipe lying on the snow close to the prints of my feet, made on dismounting from my horse.

The younger of the two Indians that hunted with me was the chief, although my friend, the elder one, was a far finer fellow in every way; he sat there a perfect grentleman of nature, dignified in carriage, with a mild voice and graceful manner. I complimented him on his running, and reminded him how completely he had stumped me up that afternoon; to which he merely replied with the mildest gesture, "Your gun" (alluding to my rifle) "is very heavy, and mine is light."

Next morning we lay rather late under our buffalorobes and blankets, as it had come on to snow; but as the flakes fell light and large, it cleared off in two or three hours; and when it was over we freshened up the fire, cooked and ate a little breakfast, took up our guns again, and separated, agreeing to meet at the end of the point of timber. Ramsay, the hunter, and I, took one side, and the two Indians continued along on the other.

We had been hunting about two hours without any success, when, in our rear, and at the other side of the Missouri, we heard rapid heavy firing, and were not long in guessing the cause. We divined, as we afterwards found rightly, that a battle was fighting between the Assineboines and their enemies, the Sioux, and we were in the rear of the latter. Ramsay was as brave as a lion, and we agreed not to attempt to gain the fort until we found not only our Indians, but the old man and boys. We started off to join the latter, in hopes that the chief and his brother would also adopt the same plan under the circumstances, instead of adhering: 
to our arrangement of meeting at the point. Whilsts walking along the ice on the river under the right bank, looking for a spot where we could climb up, we observed two Sioux Indians running at full speed towards us. They came very close before they perceived us, clothed as we were in white blanket capotes, and walking under a snow-covered bank. "Now," exclaimed Ramsay, in very broken English, and at the same time cocking his gun, "you take left hand one and I the right, and we will hammer them." I, however, protested against the absurdity of interfering in Indian quarrels, being quite content to save my own bones without breaking any of theirs. In order to join our friends we had to ascend the bank and cross a belt of wood, which we successfully did, although not without a little apprehension of lurking enemies. We found, on reaching the old man and the boys, that the chief and his brother had already joined them, and the boys had brought in the horses, sa we all mounted together and rode off for the river. We crossed the ice, and on arriving at the opposite side, found the enemy had taken to the timber eastward, while we had taken care to cross well to the westrard. of them. Their attack turned out a complete failure, for they had not succeeded in taking the Assineboines by surprise; and we arrived on the scene of action only in time to see the Sioux, who were all on foot, move into the timber to avoid the onset of both bands of mounted Assineboines, one from the west, and the other from the east, camp. We hastened on to the fort, where they were rejoiced to see us, thinking, from the enemy having crossed down the Yellow Stone, that they must have seen and surprised us, in which case we should most probably never have been heard of more. 'I'hey must, however, have crossed considerably above us, and to this we no doubt owed our escape; at least, so we concluded, from the account given us at the 
fort, whence the whole affair was seen, the particulars of which were as follows:-

The horse-guard was driving the horses out in the morning as usual, to seck what little grass or few willowtops they could get to browse on, in order to save the hay, which was scarce, and had not gone very far over the river before his sharp eye detected one or two of the scouts prowling about. He very quickly drove all the horses back into the fort again. Shortly aitcrwards three Assineboine lads, of from seventeen to ninetcen years of age, came to sell some wolf-skins at the fort. They were warned by the traders that their enemies were in the neighbourhood, and had been seen that morning; but, Indian-like, would not believe it, taking it into their heads that Mr. Kipp had some object in detaining them. The eldest said, "Come, let us go." And they set off, in spite of all warning and advice, for the lower camp, about thirteen miles off. They had not gone above two hundred yards, when they were seen from the timber, at the other side of the Missouri, where the main body of one hundred Sioux were concealed. The progress of the poor boys, whom it was now quite impossible to apprise of their danger, was watched through a telescope from the fort. Unconscious of their perilous situation they at last sat down in a sheltered sunny spot, about two miles from the fort, and commenced smoling the long Indian pipe, which, according to native custom, they handed from one to another. Several of the Sioux were now secn running through the willows and timber, creeping stealthily under the bank of the frozen river. Both pursuers and pursued ware distinctly visible from the zort; the powers of the telescope approximating now the cheerful, laughing faces of the unconscious boys, now the crouching forms of their enemies, and increasing to a painful degree the feeling of their inability to avert 
their apparently inevitable doom. Suddenly, when the Sioux were within gun-shot of their prey, one of the lads was seen to give a slight start (an Indian is never entirely off his guard); all three glancing once behind them, gave a convulsive bound, and then commenced the race for life or death. T'hirteen miles must have been run by these brave lads through deep snow, in an hour and a half. At last, towards the end of the race, their bloodthirsty pursuers by firing several shots alarmed the Assineboine camp, of the position of which they were ignorant, and for which the boys were making; so that the latter had not reached it when its inmates were already on the alert. The warriors and braves assembled rapidly, and instantly despatched a messenger to the western camp with tidings of what had occurred, and directions for mounted men to go down to their assistance, which, by passing along the brow of the hills where the snow was less deep, they speedily did. The Assineboines by this movement appeared both in front and rear of their enemies, who, having no horses, were compelled to betake themselves to the timber, with several of their party wounded. The heavy firing which we had heard now commenced, but as the combatants kept at a very respectful distance from each other, the result of this great battle was that one of the Sioux was slain and fell into the hands of the Assincboines, who immediately scalped him, and celebrated next day a grand scalp dance, similar to one I have already described. We were very sorry that evening to learn that these rascally Sioux had shot a good many of our milchcows-nearly half of them, indeed-with their arrows, and several of them fatally. The first intimation we had of it was from seeing their fine old thorough-bred bull walk across the river, tracking his course with blood, into the fort, and up to the foot of the staff from which floated the colours of his country, and there sink 
down and expire. Poor fellow! I often rejoice that I knew not, when Ramsay and I met the two Sioux, what barbarities they had just been practising on our poor cattle, or I fear I should have acted on his suggrestion, and have shot them both.

The loss of this handsome, noble animal was universally regretted in the fort, for besides his great value as their only means of continuing the breed of domestic cattle in that remote region, he proved most useful in drawing home many a heavy load of meat, and much of the mood for the fuel in the fort; as a tribute to his memory, I must here record a single combat of his with a bison, which, according to the description of his keeper, "Black Joseph," must have been truly Homeric.

About three months previous to my arrival at Fort Union, and in the height of the buffalo breeding season, when their bulls are sometimes very fierce, Joe was taking the Fort Union bull, with a cart, into a point on the river above the fort, in order to draw home a load of wood, which had been previously cut and piled ready for transportation the day before, when a very large old bison bull stood right in the cart track, pawing up the earth, and roaring, ready to dispute the passage with him. On a nearer approach, instead of flying at the sight of the man that accompanied the cart, the bison made a headlong charge. Joe had barely time to remove his bull's head-stall and escape up a tree, being utterly unable to assist his four-footed friend, whom he left to his own resources. Bison and bull, now in mortal combat, met midway with a shock that made the earth tremble. Our previously docile gentle animal suddenly became transformed into a furious beast, springing from side to side, whirling round as the buffalo attempted to take him in flank, alternately upsetting and righting the cart again, which he banged from side to side, and whirled about as if it had been a 
band-box. Joe, safe out of harm's ray, looked down from the tree at his champion's proceedings, at first deploring the apparent disadvantage he laboured under, from being harnessed to a cart; but when the fight had lasted long and furious, and it was evident that both combatants had determined that one or other of them must fall, his eyes were opened to the value of the protection afforded by the harness, and especially by the thick strong shafts of the cart against the short horns of the bison, who, although he bore him over and over again down on his haunches, could not wound him severely. On the other hand, the long sharp horns of the brave Fort Union bull began to tell on the furrowed sides of his antagonist, until the final charge brought the bison, with a furious bound, dead under our hero's feet, whose long fine-drawn horn was deep driven into his adversary's heart. With a cheer that made the woods ring again, down clambered Joe, and while triumphantly caressing, also carefully examined his chivalrous companion, who, although bruised, blown, and covered with foam, had escaped uninjured.

It required all Joe's nigger eloquence to persuade the bull to leave the slain antagonist, over whom he long stood watching, evidently expecting him to get up again to renew the combat, Joe all the while coaxing him forward with, "Him dear good bull, him go home now, and do no more work to-day," which prospect, "black Joe," in common with all his sable brethren, considered as the acme of sublunary felicity.

Indians out on a war-party spare neither age nor sex, considering any murders of wornen or children not only as just reprisals for former injuries, but even as actions worthy of proclamation in council and at the wardance; formerly, however, they never waged war nor committed any depredations against the whites, on the plea of their bcing "medicine," or mysterious people. 
Catlin met even with civilities from war-parties during his wanderings. Unfortunately, however, instances have occurred, some few years ago, of white men joining in Indian encounters, the consequence of which now is that they are no longer safe from their attacks, unless in a position to make a good fight of it.

I set out early one fine morning in January, and silled two fat buffaloes not far from the fort. This was at the time that the mumps had placed all spare hands on the sick-list. As the spot where the buffaloes had fallen was not more than two miles from the fort, I threw my saddle-cloth on one, and some portion of my clothing to frighten the wolves from the other, and returned to dinner, after which I invited some of the ladies of the fort to come and cut them up. The day was beautiful, the sun brilliant, and not a breath of air stirring. I put a horse to one of the sleighs, and took three of the fair ones on it,-trro, wives of gentlemen, the third the "placens uxor" of the blacksmith at the fort. It was quite a party of pleasure for them, and by the way in which they performed the cutting-up, that operation seemed to afford a considerable share of their enjoyment. They skinned and sliced slowly and deliberately, and with evident relish, not only dabbling in the blood, but actually drinking it, the youngest laughing at my aversion, and offering me some in the palms of her hands. The horse-guard saw us from a distance, and came to help ; but when he began to make the incision inside instead of down the outside of the hind leg, and would so have spoiled its shape for making a robe, she effectually stopped him by smashing his lat down over his eyes, exclaiming, "Wihcatko" (i.e. fool), and laughing heartily at the figure he cut when bonneted: the good-natured fellow taking it in very good part.

As the cold increased the wolves howled most dismally, 
and the cadences of roices from a high key to a low one, and vice versâ, were most extraordinary, and sometimes so extravagantiy dismal as to be quite ludicrous. There appeared to me to be three different kinds of wolves, in which impression I was confirmed by the hunters and Indians, although seientife men assert that there is but one. But I have shot a great many, and there certainly seemed to me to be three distinct species: the large white wolf, or buffalo wolf, the grey wolf, and the kit wolf. The remnants of my slaughtered buffaloes in and on the outskirts of the timber, or points, frequently afforded me opportunities of stalking up the wolves, at which I was very successful, for their gait is so smooth as to render them a much easier mark than deer when running, and I could hit them then with almost the same certainty as when standing still. There is no food for which these brutes have a greater relish than that of their own species: and I have always found myself pretty certain of getting a second shot a few hours after killing one, by removing the skin and placing his carcass in a favourable spot for stalking, which is always more or less difficult, as their senses of smell, sight, and. hearing are very acute.

I found a strange peculiarity in the large white wolf, who sleeps so soundly as frequently to allow of a very near approach; once I came so close upon one of them as to think him dead, and was on the point of examining him, when he suddenly woke up and started off at full speed. So ncar was I to him, that I was able to remove my gun-cover in time to send a bullet after him, which effectually stopped his career.

I found wolf-shooting not only capital sport, but profitable employment, being allowed in barter the value of two dollars a-piece for white wolf-skins, one and a half dollars for the grey, and seventy-five cents 


for the kit wolf-skins. The hunters used to kill them sometimes with traps set at night; but when one was once seen caught, all the wolves rrere for a long time very wary.

During my stay at Fort Union, I was frequently surprised at the friendly relations between our domestic cattle and the buffaloes, among whom they mingled without the slightest hesitation. This circumstance is the more remarkable from the fact that the auroch of Lithuania, which is of all the ox genus most similar in species to the bison, evinces the utmost antipathy to domestic cattle, furiously attacking either cow or bull whenever they chance to meet them. I was still more astonished, on attentively observing this friendly intercourse, to see our little calves apparently preferring the companionship of the bison, particularly that of the most colossal bulls, to that of their own species. I took an opportunity one morning of investigating the reason of this more closely, and availing myself of some broken ground, beyond which I saw three of our poor little half-starved calves in company with two gigantic bulls, I crept up very carefully, and lay under the brow of a hill, not fifty yards from the nearest in order to observe them, and was not long in discovering that the bison has the power of removing the snow with his admirably-shaped shovel-nose, so as to obtain the grass underneath it. His litile companions, unable to remove the frozen obstacle for themselves, were thankfully and fearlessly feeding in his wake; the little heads of two of them visible every now and then, contesting an exposed morsel under his very beard. It was an interesting sight, and I crept softly away again, so as not to disturb them.

Although the bison scrapes the snow with his nose, I do not think he does so with his hoofs. I have 
frequently seen the snow, where buffalo have been feeding, stained with slight signs of blood, and after having shot them, found the noses of both cow and bull sore from the constant shovelling.

\section{CHAPTER VI.}

Tossed by a Buffalo.-Elk-shonting.-Wolves.-Spoil a Cannibal Feast.-Ishmah.-Hard up for Ment.-Owen M'Kenzie's Post. - The Traders.

ONE beautiful clear cold morning in January, I started to shoot some prairie forl. These birds were too wild to shoot with shot, especially with the very inadequate powder imported by the traders into the Indian country; so I took my single-barrelled rifle, and shot them off the branches of the high trees where they used to sit sunning themselves, taking the lower first, that his fall might not alarm his companions. This sort of shooting is very pretty rifle practice, especially as the prairie-hen does not always fly away if you miss, but allows a second shot. Indeed, I have sometimes been amused at seeing the unconscious bird, on fecling the wind of the bullet, peck with his bill in the direction of it, giving an angry chuckle as it whizzed past him.

I had not been long at this sport when an Indian overtook me, and said in Sioux, "Ho! my friend [how coonah], I saw the track of your long foot in the snow." He wanted me to help him in stalking up three buffalo bulls that were feeding in some willows at a little distance. I accordingly started off with him, and when we came within about a third of a mile of the spot, I went carefully round to leeward, and directed the Indian to go and give them his wind by approaching on the other 
side, as soon as he thought $I$ had reached my intended post, whither I knew they would make in order to pass through to the open plain. So accurately had the Indian calculated time and distance, that I was hardly at my place, when a huge bull thundered headlong by nie, and received a shot low and close behind the shoulder as he passed. He stumbled on for about ten paces, and lay quietly down. I waited to reload, and on going up found him stone dead. The Indian then joined me, and said that the other two bulls had not gone far, but had taken different directions, so we agreed that he should pursuc one, and I the other.

I soon came in sight of mine. He was standing a little way off on the open plain, but the skirting willows and brushwood afforded me cover within eighty yards of him, profiting by which I crept up, and taking a deliberate aim, fired. The bull gave a convulsive start, moved off a little way, and turned his broadside again to me. I fired again, over a hundred yards this time; he did not stir. I loaded and fired the third time, whereupon he turned and faced me, as if about to show fight. As I was loading for a fourth shot he tottered forward a step or two, and I thought he mas about to fall, so I waited for a little while, but as he did not come down I determined to go up and finish him. Walking up, therefore, to within thirty paces of him, till I could actually see his eyes rolling, I fired for the fourth time directly at the region of the heart, as I thought, but to my utter amazement up went his tail and down went his head, and with a speed that I thought him little capable of, he was upon me in a twinkling. I ran hard for it, but he rapidly overhauled me, and my situation was becoming anything but pleasant. Thinking he might, like our own bulls, shut the eyes in making a oharge, I swerved suddenly to one side to escape the shock, but, to my horror, I failed in dodging him, for 
he bolted round quicker than I did, and affording me barely time to protect my stomach with the stock of my rifle, and to turn myself sideways as I sustained the charge, in the hopes of getting between his horns, he came plump upon me with a shock like an earthquake. My rifle-stock was shivered to pieces by one horn, my clothes torn by the other; I flew into mid-air, scattering my prairie-hens and rabbits, which had hitherto hung dangling by leathern thongs from my belt, in all directions, till landing at last, I fell unhurt in the snow, and almost over me-fortunately not quiterolled my infuriated antagonist, and subsided in a snowdrift. I was luckily not the least injured, the force of the blow having been perfectly deadened by the enormous mass of fur, wool, and hair, that clothed his shaggy head-piece.

As the next day proved alike beautifully calm and sunny, I started off to the scene of my yesterday's adventure, in hopes of finding a wolf busy at the carcass of the buffalo. Nor was I disappointed, for as I came near the spot, I saw a splendid cream-coloured wolf tearing away at the remains of my late antagonist. I crept up under cover of the brushwood, till within forty yards of him, when he cantered off, affording me a delightful cross shot to the left, which brought him quickly to with a bullet through his flanks. With a slight guttural growl he turned, snapped at the wound, performed a brilliant summersault, and after rolling over twice or thrice, expired. I then proceeded to take off the finest wolî-skin I ever saw before or since, and one which to this day is much admired by many brother sportsmen. After which, fastening one end of my belt to the hind feet, I dragged the carcass to a favourable spot, and one easily approachable, in order to obtain a shot at the next fellow that might come to feast on the remains of his comrade. 
As this was not likely, however, to occur for some hours, I left the place determining to return thither in the evening, and started off through the timber in quest of deer. After walking carefully for about a couple of hours, I fell in with fresh elk tracks, which I noiselessly and cautiously pursued for some distance, keeping is vigilant watch on all sides for any object in motion however trivial, till as I neared the end of the point out in the willows, I saw the whole band slowly defiling; the stately old stags bearing their ponderous antler's almost on their haunches. I had been obliged to go very fast-and to do that without making is noise in a thick woo is no ensy matter; the continual stooping to avoid the rustling of branches rendering it very laborious, especially when rumning with a heavy rifie. At last I gained range near enough for a broadside shot at a very fine stag. I drew up my rifie and took a deliberate aim, breathless as I was. I heard the ball crack against his ribs, and knew instantly by the sound that the charge of powder had been too small. The next instant the whole herd were bounding away at full speed. I followed after them almost in despair at losing: my noble wapiti.* Beyond the edge of the willows away they went over the open plain skirting the river. Once out of the trees, without waiting to untie my snow-shoes, I drew my knife and cut the thong by which they hung from my neck, slipped my feet into them, and pressed on with redoubled speed, my hopes reviving rapidly as I saw my star begin to fall in the rear of the band, and his pace slacken to a sling trot. By my delay with the snow-shoes I had recovered my wind, and the comparative ease I experienced as they bore me over the broad bosom of the snow, while the

* Elk is the name given in the common parlance of the country so the wapiti, similarly to the term buffalo, which is used in speak ng of the bison. 
wapiti floundered almost breast deep, inspired me with fresh confidence. At last my stag fell, got up, gave a few struggling bounds, and fell again on my approach. Seeing he could not escape, I pursued the others, now hidden from my sight by the river's bank, but only reached the ice's edge in time to see them gain the willows out of shot on the opposite shore.

One of the grand stags in particular excited my admiration. In rushing against the strong grey willows his ponderous branching horns received such a shock as to fling him over backwards on the frozen river; the clatter of his antlers I could hear loudly, even at the distance where I stood; but, nothing daunted, with nose up in the air, and his antlers lying along his flanks, he renewed the charge, and with one more desperate effort crashed through, followed by the terrified band, who, one by one, were rapidly lost to my view as the willows closed round them. Feeling that further pursuit would be useless, I retraced my steps to where the elk I had shot had fallen, and found him a magnificent prize indeed, - an animal upwards of five feet high at the shoulder, and bearing ponderous antlers. I could not but think how many of my Scottish brother sportsmen would have sympathised in the triumph with which I surveyed his magnificent proportions.

Although there are many points in which the red deer and the wapiti, or ell-stag, assimilate, they are nevertheless totally different animals. The rapiti, in the daytime chooses the thickest cover in which to conceal himself, nor does he leave it except for pasture or water. A whole band will migrate at a time from one point to another, and their pace is then a splendid trot, never breaking into a gallop, unless they are alarmed. In general appearance the wapiti is not only much larger than the Scotch deer, but formed in far more massive proportions-proportions calculated for the sup- 

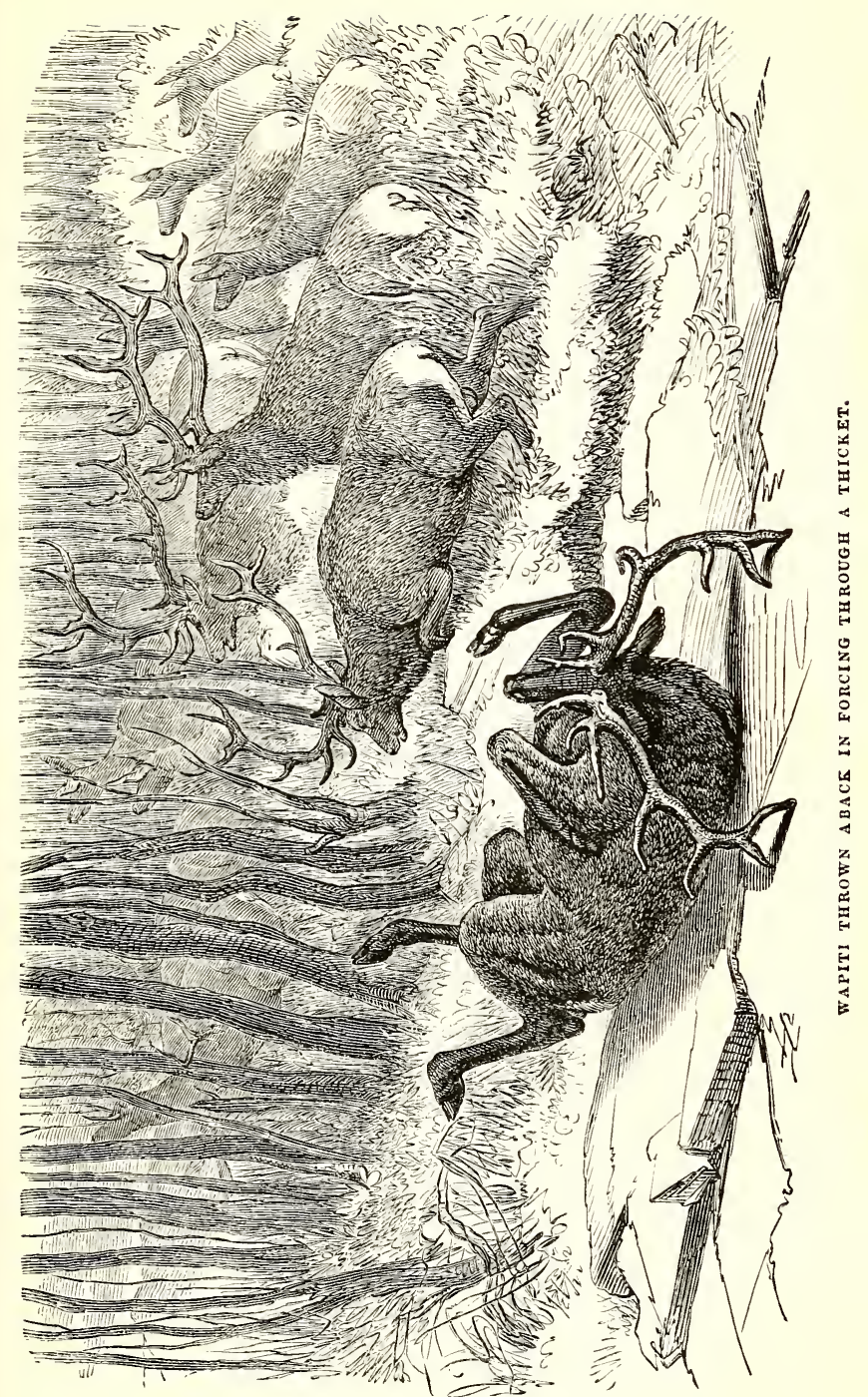

port of his ponderous antlers, which he does not. however, carry so majestically as the Scotch deer does his little ones. The head and horns of a large male, measuring from five feet eight inches to six feet two inches, will weigh sixty or seventy pounds; the horns grow in a direction almost parallel with the line of the forehead ; so that when the animal is trotting, the antlers lap over his flanks and protect him from the lashing of the heavy willows; the points, when the antlers are in that position, bending backwards and inwards, in such a manner as to remove all elastic obstacles from his headlong career. I have sometimes stood amazed to see one of these enormous animals carried at one single bound out of view in a densely thick wood, where one might suppose such a stack of antlers would have wedged him in the trees beyond all chance of escape. The head itself is about the size of that of a Devonshire cow, and of a dark bay colour. The neck and dewlap are furnished with a splendid black mane; the forelegs are clean, made like those of a very large handsome mule, with hoofs as large as those of a four-year-old bull. The eye is encircled by hair of a pale buff colour, similar to that on the rump of the animal. The body changes in colour at every season of the year ; its summer coat is of a strong red colour, which again turns into a bluish hue, gradually approaching the winter grey of the willows as the season advances, nor does it begin to assume its summer tint again until spring has nearly clothed all nature in her favourite green. In the breeding season, the wapiti*

* It is a remarkable fact, that though a tract of wood may con. tain wapiti, yet the difficulty of seeing them in time to obtain a shot, or indeed of finding them at all, requires so much practice, that an inexperienced hand might wander through the points of a western river all day and find none, or, what is much more dis. heartening, tread across a rotten stick, or otherwise accidentally snap a twig or branch, and thus afford himself the gratification of 
chants the most beautiful musical sound in all the animal creation; it is like the sound of an enormous soft flute, uttered in a most coaxing tone.

I had still sufficient daylight to visit the carcass of the wolf I had shot in the morning; so piling up a quantity of fallen timber and branches in a grotesque fashion over the elk, to preserve it from the prying voracity of the wolves, I retraced my steps, and on approaching the spot carefully, spied a brother cannibal tearing ravenously at the remains of his probably quondam comrade. I shot him dead without the smallest compunction, not even giving him the chance of a run, and speedily possessed myself of his magnificent skin, which I took with me, not reaching the fort till long after dark. Next day they very good-naturedly brought in the antlers of my elk along with the meat, which, thanks to my precautions, had escaped the depredations of the wolves, who, poor brutes, suffer horribly from the pangs of hunger, and will at those times dare almost anything short of an attack on man.

Among the numerous dogns that used to come prowl-

observing the animal's tail wave up and down as it disappears in the distance.

We had an instance of this at Fort Union in the case of a Keutucky man, who, though an excellent shot with a rifle at a mark or at prairie-hens on the trees, and constantly challenging us hunters to a trial of skill, was, from being a bad rider, very unsuccessful at buffalo; and when the hunters returned laden with meat after a fortunate run, used to say, "Well! now that's mighty fine, but I'll astonish you yet at deer and elk in the woods." Accordingly one day he set off with Smith and Ramsay, the Fort Union hunters, who afterwards told me, that they had taken a good hunt of three days, camping out twice, and bagged five elk and seven deer; but the Kentucky rifleman, accustomed to such plain clear marks as turkeys and squirrels perched on tree-top, could not get a single shot; and even on more than one occasion lost the hunters their chance by their endeavouring to afford him a shot at game pointed out in vain to bim, but which their keen practised eyes found no difficulty in detecting. 
ing about Fort Union from the Indian camps was a rery fine specimen of a mongrel, between a white buffalo wolf and a common Indian bitch. This fellow was quite white, like his sire, and furnished both with the hair of the dog and a fine undergrowth of fur, which he had in common with the wolf. The skin of his nose was also like that of his sire, quite white. The Fort was his favourite resort, where, on the fine frosty moonlight nights, he used to howl in the most piteous and intolerable manner, disturbing old Mr. Kipp's slumbers to that degree, that notwithstanding the intense cold, and much to my amusement, the old gentleman used to rush out in his shirt, roar at him and pelt him with sticks, or any other missile that came to hand, and then run back half frozen into bed again.

I took a great fancy to this dog, discovered his omners, and sent a message to them by a young Indian, who came to the fort one day. Accordingly, the same evening arrived an old Indian named Peekay, and his old squaw; they came to the door of the room where Mr. Denig and I had been smoking for some hours. First entered the old woman to negotiate the sale of the dog, but had no sooner crossed the threshold than she was seized with a violent fit of coughing; after a few efforis to articulate, she rushed out of the room again, and we were considerably entertained at hearing her receive a sound scolding from the old man outside. He, in his turn, now came in to trade the dog (as they say in Indian parlance), but had no sooner made his appearance, than he too retreated in a paroxysm of coughing. We then heard them laughing heartily outside. Shortly afterwards old Peekay returned, and as soon as his lungs were a little accustomed to the atmosphere of the room, we entered on the negotiation, and I finally purchased the dog, with his travail and harness.

I presently found, however, that was far more easily 
done than the dog secured, for his fear of white men was so great, that I do believe it would have been a difficult matter to approach near enough to shoot him had I been so disposed. The moment he saw me he used to run off to the distance of about 250 yards, and in spite of all my coaxing him to allow me a nearer approach, kept most studiously at that distance, retreating slowly or rapidly, according as I advanced in my endeavours to cultivate a nearer acquaintance. At last I had to go away and obtain the old squaw's assistance, who brought him back with a rope round his neck, the drag of which he obeyed with great reluctance, and as soon as he came in sight of me made the most violent efforts to escape. I took him into the fort, however, and having fastened him up, brought him some meat, but he would not eat it. I threw it before him and retired to some distance, when, instead of taking the meat, he seized the cord in his mouth, at the same time placing his paw uponit, drew his teeth two or three times quickly across it, severing it completely, and dashed right through the window and out of the fort; his splendid white bushy tail carried straight out behind him like a fox's brush. "Holy Moses!" exclaimed Mr. Denig, " don't he streak it like a flash of greased lightning!" Poor "Ishmah !"* how well I afterwards learned to guess what mischief he had been about, or what misdemeanour he intended to perpetrate, when he carried his tail, which was usually curled over his back, in that manner.

Old Peekay's wife brought him back to me next day, and harnessed him to his travail, which I commenced packing, for I was on the point of starting with a couple of voyageurs on a journey to White River. My effects consisted of a dressed leather elk-skin, a buffalo-robe, two blankets, three or four pairs of mocassins; a large

* So named frnm an Indian word descriptive of his fine thick fur. 
and a small tin mug (the former for cooking, the latter for diinking from); half a stone of lead for bullets; powder, and coffee. I was accompanied for a little way by two voyageurs from the fort, in charge of a couple of mules harnessed to a sleigh, who were proceeding with goods, in order to set up in opposition to some new traders who had established themselves in an Assineboine camp.

The snow was deep, and the difficulty of dragging the sleigh very great. At night, or rather towards evening, some little while before sunset, we chose a suitable place for our camp, generally among willows surrounded by timber. We then cut down two good-sized trees, which we laid parallel to each other along the snow, forming a basis for building our fire on, and collected wood, lighted our fire, and proceeded to cook as I have before described. In addition, however, to preparing their own suppers, the men had to supply the mules with food, for the country was covered with snow, and the poor animals could procure nothing for themselves. For this purpose the voyageurs cut down cotton-wood of a certain growth, about the thickness of a man's leg; this they cut into lengths of three feet or so, and then piled them in the vicinity of the fire sufficiently near to thaw the bark from the wood, and to render it easily removable by a drawing-knife, with which these men are expressly provided, and thus they supply the animals under their charge. It was amusing sometimes to observe the poor mules intently watching the operation. My dog, however, like myself, depended on what I could provide with my rifle.

In order to supply ourselves and the mules with water, we had to cut through the ice of the Missouri between three and four feet thick, and sometimes more, with a hatchet. As for Ishmah, nothing would induce him to drink out of this hole, so he generally quenched 
his thirst by eating snow. Notwithstanding the great thickness of the ice, broken spaces remain open during the whole winter all along the river, at intervals varying two, three, or four miles from one another. These breaks are termed air-holes, and frequently extend their surface of unfrozen waters over acres. Along the edges of these air-holes the ice is so thin as to render an approach to the water's edge very dangerous, where like glass, it will suddenly crush under foot, precipitating man or beast into a resistless current of water, quickly forcing them under the ice's opposite edge to a fearful frozen tomb. These air-holes, on account of the weakness of their surrounding ice, cause the drowning of a great many buffalo, elk, and even some few bears, tempted probably by a fine sunny day to leave their winter retreat for an hour or two prowling on the ice. 'This fact impressed me with the idea, that those remains of our gigantic fossil fallow deer now dug out from bogs in Ireland were perhaps thus destroyed, which would account both for the localities where they are usually discovered, and for the numbers found together in one spot. Some have fancifully supposed that they were domesticated, in proof of which theory they assert that the skulls of dogs have been found along with them; but this I do not think to be the case, for all that ever were shown to me as found with the remains of these fossil deer, are the skulls of very large bears.

Ishmah had a horror of approaching these air-holes, which nothing would induce him to overcome. It was some time before he became friends with me, and for the first two days of my journey from Fort Union, had to be dragged behind the sledge. By-and-by, however, he gradually overcame his aversion to white men, at first following at the distance of nearly a quarter of a mile, and then by degrees venturing of his own accord on a nearer approach, encouraged by some pieces of meat which I 
threw to him from time to time. On awaking one morning I found him lying close to my side on the edge of my buffalo-robe, but the instant I put out my hand to caress him, he bolted off to a respectful distance, which he gradually lessened, coming nearer and nearer till he became comparatively quite friendly towards me.

Shortly afterwards my tro companions parted from me and proceeded to their destination, whilst I remained alone with my faithful dog, bound for Fort Mackenzie. Ishman had by this time overcome all prejudices against a white master, and a more faithful, efficient, and devoted creature never breathed. From morning till night, he struggled on, drawing his travail laden with all my effects, and, in addition to their weight, meat from the last deer I had shot. I travelled generally along the ice, and during the whole of my solitary journey I never ventured far from the river-a very necessary precaution in that country, where an unhappy voyageur, tempted by a fine day or bright sunshine, ventures on a short cut across one of the many gigantic bends oi the tortuous upper Missouri, and perhaps the very moment previous to the accomplishment of his object might be the commencement of a pitiless storm, veiling all woods and other objects from his sight in wreaths of whirling snow, causing its victim to wander generally round and round in a small circle, perhaps all the while close to the shelter so eagerly sought: in vain he endeavours to reach material wherewith to light a fire, until at last thrown down numbed, he lies wrapped up in his frozen shroud.

The woods along the banks of the river afforded me timber, already fallen and in every stage of decomposition, wherewith to light a fire at night; and when I stood and looked about me to choose a convenient spot near an ice-hole, Ishmah used to gaze into my face as if he could read my thoughts, and whine as much as to say, "I am tired too." "When I trampled down the 
snow, cut and strewed the willows, and proceeded to collect the wood, he used to watch me eagerly, and prick up his ears when he saw me take the flint and steel from my pouch and the dry inner bark of the cotton-wood tree from my chest in which to kindle the spark. The fire secure and burning well, I turned my attention to him, unharnessed him, unpacked his travail, and placed it aloft against the side of a tree to protect the leather straps from the voracity of the wolves. This done I spread my bed and filled the kettles with water, took a handful of coffee-berries from my bag, which I roasted in the cover of the kettle, then wrapping them up in a piece of leather, I pounded them on a stump and put them in the smaller kettle to boil, reserving the large one for the meat. These culinary proceedings Ishmah used to regard with the most intense interest, turning back from time to time as the eddies of pungent smoke from the damp fuel compelled him to avert his eyes. When supper was at last cooked and despatched (quickly enough on his part, poor fellow, for his share was sometimes very scanty), he sat up close beside me as I smoked my pipe and sipped my coffee; and when at last I got into bed, he used to lie down at the edge of the robe with his back close up against my shoulders, and so we slept till morning. As soon as it was daylight we rose, Ishmah submitted patiently to be harnessed, and we resumed our march.

This was our routine for several days until the meat was exhausted. I then ceased travelling at twelve o'clock, so as to allow myself time to hunt for supper and prepare camp for the night. My difficulties in foraging were considerably increased by the necessity of the dog's following me, and I had at first much difficulty in teaching him to keep behind, but I succeeded eventually, and was fortunate that day in stalking and knocking over an old buffalo bull. I helped myself to 
the tongue, kidneys, two marrow-bones, and a plentiful supply of meat, and was returning well laden to the spot where I had left the dog's travail, when, to my horror, I perceived a wolf there, which started off lons before I could get within shooting distance. I ran up to the spot and found that the brute had already commenced making a meal of the harness, and had eater the straps and a part of the collar. Fortunately, however, the mischief was easily repaired, as I had spare leather and materials for sewing, and merely afforded me a little occupation after supper, ere I lay down for the night. I had now an ample supply of meat for some time, and for two days more marched on as usual, when another catastrophe, and one which might have proved very serious, occurred to me on my solitary journéy.

Ishmah's relationship to the Lupus family was often productive of much inconvenience to me, as he used to run off and engage in play with the young wolves, chasing and being chased by them in turn. At first I was amused at this indication of his wild origin, but became subsequently much annoyed, and on one occasion seriously alarmed, at the result of these gambols. One day, after a long march, I was looking out for a convenient camping-place, when a she-wolf crossed the ice at some distance from where I was standing. In spite of all my exertions and threats, Ishmah immediately gave chase, and they continued their gambols, until I attempted to approacl them, when, of course, the wolf made off at full speed, followed by my dog, with his travail behind him, loaded with everything $\mathbf{I}$ then possessed in the world. I followed, shouting after him in vain, until he entirely disappeared from my view, after which I continued running on the tracks, till darkness obliged me to abandon the pursuit, and I found myself a long way from timber, out on the broad 
prairie, alone on a vast barren waste of snow stretching around me on every side.

My sensations were anything but enviable, on reflecting that I was about one hundred miles from any known habitation, and nearly one hundred and fifty from my destination, destitute of robe and blankets, with but very little powder in my horn, and only two bullets in my pouch. In short, I was in a pretty considerable sort of a "fix," and had nothing for it but to rnake tracks again with all speed for the timber. Fortunately, I found my way back to the river without much difficulty. It was a beautiful moonlight night, which enabled me to collect some fallen wood, and having lighted a fire, I seated myself beside it, and began to consider the probabilities of my ever reaching a trading-post alive, in the event of Ishmah not returning, and how I should economise my ammunition and increase my rate of travelling, so as to effect this object. Miy prospects were dismal enough, nor did I feel cheered as the cold north breeze froze the perspiration which had run down my forehead and face, and formed icicles in my beard and whiskers, that jingled like bells as I shook my head in dismissing from my mind one project after another. At last resigning myself to my fate I took out my pipe, determined to console myself with a smoke, when, alas! on feeling for tobacco I found that was gone too. This was the climax of my misfortunes! I looked to the north star and calculated by the position of the Plough that it must have been about ten o'clock, the time at which in England we have our knees under the mahogany, surrounded by friends, discussing a bottle of the best, and awaiting the summons to tea in the dratring-room. I tried to see a faint similarity to the steam of the tea-urn in the smoke from the snow-covered rood on my dreary fire, and endeavoured to trace the forms of sweet familiar faces in the embers, till I almosts 
heard the rustling of fresh white crèpe dresses round me, when, hark! I did hear a rustle-it approaches nearer, nearer, and I recognise the scraping of Ishmah's travail on the snow; another moment and the panting rascal was by my side! I never felt so relieved, and laughed out loud from shecr joy, as I noticed the consciousness he showed by his various cringing movements of having behaved very badly. I was too well pleased, however, at his reappearance to beat him, particularly when I found nothing of his harness and load either missing or injured in the slightest degree. Even the portion of meat which I had secured from the last deer I shot was untouched; so that I had nothing to do but unpack the travail, make my bed, and cook our supper.

The next day was very cold, in consequence of a rortherly wind, which blew pretty hard. In these regions the cold in winter is always easily supportable in calm weather; but the cold, when accompanied by wind, becomes so piercing, that great care and constant activity are requisite when travelling to avoid frostbites. I therefore collected a quantity of fallon and decayed timber and bark, and built myself a comfortable little hut, in which I weathered the storm tolerably well. Towards noon it began to snow, and continued all night, filling all the crevices between the layers of bark, willow, \&c., that formed the roof and sides of my cabin, thus further contributing to my comfort, which was only disturbed, at intervals of a few hours, by my having to go out and renew my fire. The following day I continued my journey until a little after noon, when, having no more meat, I unharnessed the dog and set off to hunt for my supper. That game was very scarce here, I soon found, as I searched fruitlessly for tracks in the recently fallen snow. I hunted long and hard, but in vain; night was stealing on me, and I was compelled to avail myself of the small portion of 
daylight that remained to retrace my steps to the spot where I had left my travail, where I made my camp, and went supperless to bed.

Next morning I arose, and debated with myself for some time, whether I should begin by another hunt in this unpromising region, or pack up and resume my journey until after noon, as I had done on the previous day. After a little deliberation I adopted the latter plan, and travelled on until about noon, when I fell in with some fresh wapiti tracks. These I pursued for a long distance, and at last came in sight of some does, who unfortunately were so far out on the plain, as to defy every possible effort of mine to approach them. My stalk was unsuccessful, from inability to conceal myself and my dog; had I tied him up, I knew his frantic howling would soon put every living thing in these regions on the alert, so I was compelled to let him come too. He followed as I had trained him, never attempting to precede me, but all my efforts proved fruitless; my game escaped without my being able even to venture a shot, and I had the mortification of seeing these stately and graceful creatures break away at a rapid trot, which they soon increased to a gallop that speedily carried them out of sight, and thus vanished my chance of supper for another night. I felt very hungry indeed, and was besides very tired. I slept feverishly, awaked at intervals from visions of the most rare and delicious dishes placed before me. I dreamed I stood before the hospitable mansion of an old friend, who led me, in spite of my incongruous costume, into his brilliantly-lighted parlour, and placed me down to a table loaded with all the delicacies of every season and climate under heaven, including tro soups and a turbot! At last, when porrdered footmen removed the richly-chased covers off these exquisite deli-. acies, I started up wide awake, to look on naught but 
snow, and finally I solaced myself with a pipe. On the day following I hunted long and hard till considerably after noon without success. The painful sickening. sensation of hunger had now quite left me, and I suffered much less on the third than on the second day. Strange to say, I had not the least apprehension for the future, but felt perfectly confident the whole time that sooner or later I should fall in with game. At last I came to some fresh tracks of deer, and soon made out that the animal had not only been walking quietly, but ras in the rillows close by: this I rightly guessed by the zigzag direction of the tracks; for deer, before lying down, walk slowly from side to side, as if hesitating where to stop. I remained perfectly still for some time, looking intently with an eye sharpened by hunger, and at length observed something stir in the willows: it was a deer; evening was advancing, and he was going out to feed. I waited anxiously as he came on, slowly feeding, most fortunately torards me, until he approached to within about 100 yards, and then stopped. I drew up my rifle, and would have fired; but he came still nearer, feeding siowly formard till he was scarcely sixty yards off, when I took a steady deliberate shot as he turned his fank towards me. I heard the bullet crack against the shoulder; he rushed a short distanice back, and rolled over in the snow. To my great satisfaction wood was close at hand, so I made a fire and cut array a little venison, which I broiled slightly, and ate sparingly of, giving the rest to my dog: I then made a rope of the deer's skin, and fastening one end to the carcass and the other round my shoulders, dragged it to my camp of the previous night, where I cooked and ate a most enormous supper, smoked my pipe, and slept comfortably.

Two days' more travelling brought me near the end 
of my journey ; on the evening after, and just as I was looking for a favourable position to camp, I saw some Indians at a distance in the direction in which I was travelling. Indians are wonderfully quick at seeing a new arrival at a camp, or post; so that my approach became, as I afterwards heard, a matter of great discussion amongst them. One or two ran off to meet me, and approached in a friendly manner. It was a great treat to hear the sound of another human voice, and even to hear my own in conversation once more; our colloquy progressed rapidly, partly by language, but principally by signs, at which they are very expert; and the result was that I did not camp at all, as they took me to the gentleman in charge of the post, where I arrived late at night. Here I was kindly welcomed, and joined my host at a delicious supper of buffalotongues, - rich cow-tongues cooked with buffalo marrow, which had been preserved in the autumn when the animals were fat, and I enjoyed it the more, as I had been living during the whole of my solitary journey on nothing but the leanest meat.

The Indians at this post were then very badly off, in consequence of the dearth of buffalo in that country, and were just about migrating. They generally hang about a trading post as long as they possibly can, in order to beg, borrow, barter, or steal anything they can get out of the traders, whose patience is sometimes severely tried. Indians, however, on the whole, are very easily managed, if their character is properiy understood. I have invariably found it the best way to fraternize with a great man or chief, make him some little presents, and then tell him that you depend on his good faith, and the fact of his being a great man, for the security of your property. For several days after my arrival, I employed myself in going round the different lodges of the Indians and visiting them. The 
men were always most friendly, the women very retiring and timid, until I came to know them well, when a good deal of their shyness wore off. One of them observed to me, on my calling her to look through a fine telescope belonging to one of the traders: "Well, the white men know by this [here she moved her hand as if writing] what happens very far off, and with this [touching the telescope] they see what is a long way off; now have they invented anything by which they can hear what is saying a long way off?"

At the White River post, I arailed myself of Orren Mackenzie's hospitable welcome, and remained in his log-house along with another trader of the American Fur Company.

Besides these two gentlemen were two other white traders, who had established themselves in a log-house at little more than gun-shot distance from them. At first I found them very unfriendly towards one another; however, I endearoured to persuade them of the absurdity of allowing any hostile feelings existing between the rival companies at home to infiuence them in their personal intercourse with one another, endenvouring to show them what a melancholy picture it was to contemplate discord among three or four isolated individuals, never seeing the face of a fellow-creature sare occasional wandering savages, and partly by arguments, but principally by ridicule, perfectly succeeded in placing them all on the most friendly terms; so much so, that they used to laugh afterwards at the fools they had been. I since found that inciting hostile feelings among their several employés is a policy pursued by the rival companies, and I received many a malediction (though not in my hearing), for the success of my efiorts in making peace.

Accordingly, Nackenzie and I fratemized with Martin and Frederick. The former was a Frenchman, 
a fine, tall, handsome fellow, with splendid abilities. Many a time did he entertain us half the night through in his log-house with his anecdotes and experiences, while his poor Indian wife lay yawning in bed, not understanding a word that was said, but unable to sleep from his wonderfully loud way of speaking, which was always accompanied by the most energetic gesticulation. A great many of his stories had the merit of being invented by himself, as well as collected from the beavertrappers and hunters of these extensive regions. Frederick was the very opposite of Martin, which probably accounted for their having lived together so long on such friendly terms; he was short, pursy, jolly, and matter-of-fact, and it was very amusing to hear him trip up Martin, as he frequently did, in some brilliant impromptu account, by a short, pithy proof that the narrator was wrong, both as to facts and chronology. My friend, Owen Mackenzie, was a particularly fine young fellow, about twenty-one, a splendid rider, firstrate shot, and, taken on the whole, on foot and on horseback, the best hunter I ever saw. His prowess was put to the test soon after my arrival, for meat becoming scarce in the Indian camp, a party of Indians contrived to root up, at night, the picket of the storehouse, and carry off all the meat that had been stored for the winter's consumption. In the morning we had the satisfaction of finding ourselves without anything to eat. Our party at that post then consisted of three or four labourers, one under-trader, an Indian woman, two children, Owen, and myself. As soon as we had discovered our loss on the following morning, we had nothing for it but to set out and hunt, and a long tedious day we had of it too. I returned home unsuccessful ; but Owen killed a deer, and singularly enough found the animal not far from our hut, as we were returning home in the evening despairing of success. Although the meat was very lean, we 
had plenty of marrow fat; and if the worst came to the worst, we could help ourselves to the dried tongues, which, as an article of trade with the Fur Company, had been hanging from the roof of the hut we slept in, and so escaped the marauding hands of the Indians.

\section{CHAPTER VII.}

Glutton Feast.-My Indian Companion.-Hunting in Snow.-Roast Loin of Wolf.-Blacktail Deer.-Rapacious Beauties.-Another Journey.-A Long Shot.-Indian Voracity. -Larpenter's Post, -Start for the Minitarees.-Awful Night.-Peekay and the Bull. - Reach Fort Berthold.

MACKENZIE and I received one evening an invitation from the Indians to one of their Glutton Feasts. The peculiarity of the ceremony obliges the guests to eat the meat when almost boiling, and they also vie with each other to prove which of them can eat most with the greatest rapidity. When we entered the lodge we found a fire lighted in the centre, and about a dozen Indians seated cross-legged around it, holding dishes or bowls cut out of solid blocks of wood. Armed with these they impatiently awaited the onslaught.

The signal was then given by two youths beating a drum, which deafening row was accompanied by the most frantic yelling; the hashed meat was then poured out into the bowls of the guests, and in this boiling state they commenced devouring it, but notwithstanding the burning of fingers and scalding of throats, they contrived to consume such enormous quantities as to cause their stomachs perceptibly to distend. During the whole time of this disgusting exhibition the drums continued beating, and the two lads never ceased howling. 
At this feast I met an Indian, who afterwards became a great ally of mine. As soon as the glutton feast had terminated, my new acquaintance accompanied me home to our log-house; and we had a long semi-telegraphic conversation over hunting matters, as we discussed an Indian pipe and a cup of coffee together.

He was one of the few Indians I ever met who was a good deer and elk hunter; for although the generality of those among them who possess horses are fine riders, and unmatched in following buffalo on horseback with bow and arrows, yet they are neither keen nor very successful in the pursuit of game on foot.

To any one skilled in using a bow, the silent arrow is far the most effectual way of "getting fat meat," as the Indians term it. The fat cows are always the swiftest; and the awkwardness of loading a goun, together with the alarm attending its discharge, will generally afford the toxophilite Indian the greater triumph at the termination of the run.

But with a gun few of them are good shots. The firearms supplied by the American Fur Company are neither good nor highly prized by these Indians, most of whom rould infinitely prefer a large green or scarlet blanket to the best gun you could offer them. Percussion guns they never will use, nor could I, ever discover their reason for objecting to them. But my new acquaintance was a remarkable exception to this rule; being a very keen hunter, he had purchased a fine long gun from the Hudson Bay Company's traders, in every respect superior to any he could obtain at the American Company's posts. This formidable weapon never missed fire; its serviceable, although clumsy lock, was provided with a main-spring strong enough for a vermin-trap.

The hunter himself was a fine tall handsome fellow, with mild and polished manners. I was particularly struck on the first evening of our acquaintance with the 
gracefulness of his gestures, as he sat talking in our loghouse, moving his hands and arms with the ease and dignity of the most accomplished rhetorician.

Before we parted that night, we arranged to hunt in company the following day; and next morning, according to agreement, he came and woke me very early ; for we had far to go, in order to hunt with any chance of success, as game was very scarce around the Indian camp. I was unsuccessful ; but he shot a deer, which we drew home over the snow before night, by attaching the hind legs to a leather band fastened round our shoulders, and so drag'ged it along to the post.

Meat was then a valuable article among the Indians, who were very badly off, buffalo having abandoned that part of the country, and these tribes being far too improvident when meat is plenty in summer, to dry the overplus and store it in time for a winter supply.

Up to this time it had been my intention to push eastward and southward back to the United States during the winter; but finding no likelihood of obtrining any travelling companions, and fearing to mdertake so long a jouney alone during this terrible winter season, I now gave up the idea altogether, and determined to remain in the Indian territories until the ice broke up on the Missouri river.

We generally had abundance of meat, such as it was, lean deer-meat being wretched food.

One day my Indian companion and I were out for many hours, and though hunting most indefatigably, had bagged nothing. It came on to snow slightly in the afternoon, and I had turned about, and was making for our rendezvons, which was at the corner of a rood not far off, when I saw, at a little distance, something grey, lying down. I looked carefully, and saw a wolf, which, on approaching, appeared to me dead, and therefore did not remove the gun-cover from my rifle. I 
walked close to the spot, and was surprised a second. time by the brute jumping up and scampering off at full. speed. I lost as little time as I could in tearing off my gun-cover, cocked my rifle, and made an excellent shot, rolling the wolf over and over. On coming up, I found. I had killed a very fine she-wolf, in prime condition. I reloaded, and put back my rifle in the gun-cover, heaved my prize on my shoulders, freshened my way as much as possible, and, nearing our rendezvous, had the pleasure of seeing the Indian rapidly aproaching me.

$\mathrm{He}$ quite surprised me by the delight he showed at my having secured the wolf.

We made ourselves pretty comfortable in the willows, near the river, and, under a bank to windward, with a good roaring fire at our feet, and well sheltered by walls of snow, which we scraped up with slabs of drift-wood, we sat down and cooked our wolf, the Indian assuring me all the while that it was a great deal nicer than lean deer-meat. Hungry, however, as a whole day's unsuccessful hunting had made me, I was still very unwilling, in spite of his assurances, to try it ; but the evident relish with which I saw him eating it, quite disarmed me of my prejudices against wolf-meat; and, in fine, I feasted on the fat ribs, which proved most palatable, and certainly very superior to lean venison. My companion laughed at observing me completely conquer my scruples, and detach a couple more ribs off the savoury fore-quarter then hissing at the fire; we certainly enjoyed our supper that night, nor was my stomach a whit the worse for the strange food, with which it had been astonished.

After supper we lighted our pipes, and smoked, dozed, and conversed alternately till sunrise, when we roasted more of the wolf, ate a good breakfast, and again continued our hunting.

As the weather looked threatening, we determined to 
keep together; and had not been hunting long when we descried four or five deer in some scattered willows. My companion being far my superior in approaching game, I desired him to stalk them, and he presently succeeded in stealing on within about a hundred and forty yards of them. After some hesitation, and presenting his gun twice, he decided not to fire, but stretching his hand cautiously behind him, made a signal for me to approach: I crawled upon my hands and knees, drawing my rifle after me in its leather guncover, until I came to where he had waited for me, in fear of missing the deer himself, for he never liked a long shot, and considered these too far.

It is always difficult to shoot with a heavy rifle when kneeling; I made use, therefore, of my companion's shoulder for a rest, and taking a careful shot, sent my bullet through the lungs of the nearest buck; all the deer dashed forward, but it was easy to see that mine could not go far, and a short run brought us up to where he had fallen dead.

We were now such a distance from home that we deliberated for a little what course to pursue, and at last we proceeded to bury our game in the snow, heaping it well to keep off the wolves, and sticking up a long pole with a red handkerchief fluttering from it to mark the spot. We then set off home, determining to bring our dogs with their travails next morning to the place and draw it home. Although it was still early, we did not hunt any more that day, as we were very tired from having sat without beds over a fire all night, but we shot one or two prairie-hens and three rabbits. We had an excellent supper that night; $M \cdot K$. treated us to choice cured buffalo-tongue and marrow-fat, with coffee; these tongues were not provisions for our ase, being articles of trade for transport to the United States, where they fetch a good price; but when we 
were short of meat we were obliged to appropriate one or two, which 0 wen Mackenzie very unwillingly granted, unless on special occasions when he and I rewarded ourselves with one of them after a successful hunting excursion.

Well do I remember how these tongues addressed themselves to the feelings of us hungry hunters, intently watching them as they hung in clusters from the beams of the roof which formed their rostrum, whence they sent forth an appeal more eloquent than the language of a Demosthenes; true, the tongues were silent, but they were fat! When well boiled they are delicious, the rind then peels off, and they become tender, plump, and juicy.

Next morning we started off for our deer which we had buried in the snow, taking Ishmah with his travail, together with another Indian dog which followed my companion.

On our way to the place I got a shot at a wolf, which I killed; we buried him after skinning him, and proceeded on our journey for some way, when at a distance my companion perceived three black-tailed deer on the higher hills overhanging the river. He started in pursuit, while I remained to take care of the dogs, that they should not interfere with him and spoil his stalk. I had an excellent view then of both the hunter and his game, which he approached with great skill; at last he got a shot, on which the animals rushed off, but one hobbled in the rear; the bullet had broken his leg. A most exciting race then commenced between the Indian and his broken-legged deer, up and down the hill over the frozen snow, my companion evincing the most astonishing powers of endurance in his persevering pursuit, gradually regaining the ground he had lost in loading as he ran; till, far in the distance I saw a puff of smoke, and before the faint report of his 
long gun reached my ear, I had the satisfaction of descrying the deer stretched in the snow.

I fastened one dog behind the sledge of the other, which I led by a string tied round his neck, and in this way ran along the river, keeping in sight of my companion, and joined him shortly after the fall of the black-tail deer.

These are a peculiar species found only in these regions, differing from the Virginian breed in the horns, which are longer, and curve more upwards; their meat, however, is not nearly so good, nor are they so difficult to approach. A black ring round the tail forms a striking characteristic, as also their very large ears; the hair of the animal's coat is long, and very handsomely coloured; in size they exceed the Virginian, and equal the Scotch.

This deer I do not think has ever graced any of our private or public zoological collections in England. It is, however, a beautiful animal, and its skin makes the best and most serviceable light leather:

Our chase after the black-tail did not take us much out of our way, so I remained behind, skinning and cutting it up, while the Indian went on with his dog and travail in order to fetch the deer I had killed the day before. The day was brilliantly fine, without any wind; and I sat by a driftrood fire that I lighted to await the arrival of my companion, who returned in a few hours, and we went home together, my dog lugging along a whole deer to his share, while the Indian and I had to carry a hind-quarter each on our shoulders to enable the other dog to draw the rest of the meat to our post, which we reached by moonlight.

Next day I witnessed a most unamiable display of feminine feeling towards a poor old woman, to whom I had given a little meat. I had resisted the importunities of several of the younger women, whose husbands 
were either too timid or too indolent to hunt for them. This old creature, however, being perfectly helpless, and not having a claim on anybody, I cut her off an abundant supply for more than a hearty meal; but as she was hobbling off in great glee, clutching the meat and drawing her robe tightly over her, she failed in escaping the keen, brilliant, black eyes of three young squaws, who immediately gave chase, and were not long in coming up with her, where (as she afterwards informed me) the following conversation took place"Are not you ashamed," exclaimed the three, "an old woman like you, to have meat to eat when three fine young women like us are starving? What do young men care for old wretched ugly creatures like you? It is for us that they care, therefore you are not to eat meat while we are hungry." So in accordance with the laws practised between the weak and the strong, these three young harpies forcibly dispossessed her of the meat, with which they decamped; and the poor old woman came back to me for more, which I gave her as soon as I had heard her story confirmed by a bystander, and desired her to go and cook it near to where I was cleaning my rifie.

This old lady, I was informed by the Indians, had seen more than ninety summers; she seemed, horrever, to enjoy a very good appetite, and despatched the tough meat with which I had supplied her with such ease and celerity, that curiosity induced me to undertake an investigation of the state of her teeth. After a little persuasion, she allowed me to look into her mouth, when to my utter astonishment I beheld every tooth in her head perfect, the back teeth firmly wedged together like so many blocks of the whitest ivory.

The weather now became very fine, and the snow had evaporated to such an extent, that we were able to bring out horses with us; but, so scarce was meat, that one 
evening, when my Indian hunting companion and I were returning with a comple of horses well laden with venison, from an elk and two deer we had killed that day, we had considerable difficulty in saving our precious cargo from the hungry crowd that gathered around us ; nor do I think we should have succeeded in guarding it, but for the interference of the soldiers of the post, who came up to our assistance.

I ought here perhaps to explain to my readers, that the soldiers of a trading post are chosen men of the Indians, conspicuous for their honesty, fidelity to the traders, and their general readiness to uphold the white men. Their zeal is frequently highly commendable; and I have witnessed noble and disinterested acts of these gentlemen of nature, which would have shamed many professing a better creed, but practising a more selfish course.

Indians have a great idea of a kind of mysterious influence attending a white man, as to safety when in his company; and I have frequently, in my hunting excursions, been attended by Indians in districts where nothing short of forming themselves into a strong party would induce them to venture.

On one of these occasions my Indian was very much influenced by this feeling, and acknowledged that he would not cross the Missouri, and hunt at that great distance from the camp, unless in my company, for fear of the war-parties.

There certainly were some grounds for apprehension on that account, as war-parties, from one tribe or other, are the whole year trying to make onslaughts on the different encampments on the borders of the Missouri, in order cither to get scalps or steal horscs.

At one time the Sioux, at another time the Blackfeet, are down upon them. Frequently, indeed, a number of their own party form themselves into a gang, and devise 
some scheme for depredation, in which attempt they themselves perhaps get surprised and cruelly murdered. In these winter expeditions they are subject to the greatest sufferings from cold and privations; and it sometimes happens that they are overtaken on the prairie by a snow-storm, and frozen to death.

On my return to the States, I learned from Mr. Murray, the commander of the Crow trading. post (whom my readers will remember I have already introduced to their acquaintance), that a war-party of seventeen Crow Indians started for scalps and horses against the Blackfeet, in the very depth of winter: they were caught in a snow-storm, and not one survived to tell the tale.

Martin, and his coadjutor Frederick, were most hospitable fellows. Owen and I used often to go over and spend the evening with them; on which occasions we were entertained with coffee and Martin's amusing stories; and I was now very glad to return the civility, by contributing some meat to their store.

One evening, when we were quietly engaged over a game of eucre, one of the rorkmen came and told us that a large wolf was prowling outside at a little distance, attracted, no doubt, by the offal of two deer that 0 wen and I had killed that morning, so close to the post, that we dragged them whole along the snow, and skinned and cut them up before the door of our house.

We took up our rifles all ready loaded, quietly opened the door, and, by the light of a nearly full moon, saw a splendid cream-coloured fellow busy at the offal of the deer. We both let fly at him, shattering his hind-leg; whereupon he made off on the other three, as hard as he could go. I threw my rifle against the wall of the house, and started in pursuit, together with Owen, followed by Martin, Frederick, and several workmen. Owen and I had a fine run, all the while vociferating and imploring 
some one of our attendants to give us a stick, stone, or anything to hammer the wolf, whom we could just barely keep up with, and knowing that if either of us once stooped for a rreapon, or missile of any kind, he could never catch up to him again. At last, some one running behind me put a good strong stick into my hand; and at the same time 0 wen, finding himself likemise supplied with one from another man who was following us, we hammered away at the wolf's head till we secured him. He was an amazingly fine wolf, of the largest species, of a cream-white colour; his skin was very large, and the fur so fine, that I saved it for my collection.

Next day almost all the Indians broke up camp and moved off, and among them my Indian hunting companion; the loss of whose society I felt very much, for he had been a great ally of mine.

Shortly after this our party was increased by the arrival of Carifel. This little fellow had been once a free trapper in the mountains, but who (in consequence of the great depression in the price of beaver) had afterwards taken service with the Fur Company. He was a jolly little French Canadian, and represented the perfect picture of a royageur as he walked in, dressed in a blue blanket coat, ornamented mocassins, a blue sailor's cap on his head, his snow-shoes fastened round his neck, and a new brass-mounted bad Belgian carbine in his hand. $\mathrm{He}$, however, prudent little man, was not at all dependent on the performance of this last item of his equipment, but had still a goodly store of dried buffalomeat, which he had carefully laid in for the journey, and had strapped behind his shoulders along with his buffalo-robe and blanket, which formed his bed when he camped at night.

Shortly afterwards, in about the middle of March, the weather broke again, and we had a tremendous 
snow-storm for three days, during which our meat was completely consumed.

The day after the termination of the snow-storm was very fine, and Mackenzie and I went out hunting; nor had we gone far before we found, to our infinite satisfaction, fresh tracks of deer, evidently driven to shelter in that point by the recent snow-storm. We followed the tracks to the edge of the point, and came in sight of two or three deer out in the open prairie, a long way off. Owen slowly drew up his rifle, singling the nearest, and made a inagnificent shot, bringing the animal right down on the spot with a shot in the neck, at the short distance of 300 yards! During this time we continued to hear shot after shot in rapid succession from Carifel, in the direction opposite to that by which we had ourselves entered. "He will set the whole wood on fire before he stops," I observed; but Mackenzie replied, "Ah, he must be in some scrape, and firing for us to come to his assistance."

On this suggestion, we both started off in the direction that this incessant firing appeared to come from; but we had not gone very far, when the firing ceased, and not long after we met Carifel himself returning, quite crest-fallen. "Qu'avez-vous donc, Carifel ?" said I. "Oh, monsieur !" replied he, "C'était une bande de biche ;" and he went on to describe how he got among a herd of elk, and set-to firing away, unperceived by them, till the poor animals got so terrified, that they kept trotting backwards and forwards, as if paralyzed by fear, until Carifel had discharged every bullet he had; and the only result was a suspicion of having wounded a doe. That really was too much for the patience of us hungry mortals to endure. We rated and abused him; but the little fellow took it all in good part, and joined in the laugh at his own expense.

I had for some time been very apprehensively ob- 
serving the short supply of copper caps with which I was now provided, and which, notwithstanding all my care and economy, was rapidly decreasing. One evening that I announced this alarming intelligence to Frederick, he advised my endeavouring to obtain a supply from some fellow-traders, who also, in opposition to the American Fur Company, had established themselves about seventy miles off, on La Rivière à Couteau. Fortunately, about this time, $O$ wen Mackenzie was sending a despatch on business to Fort Union, together with three workmen, whose services were not required at our little post, and of whom we were glad to get rid, as the additional burthen of supporting them with our rifles, in a country where game had become very scarce, was anything but desirable.

We accordingly all started one fine morning; each voyageur with his buffalo-robe and blankets strapped to his shoulders, together with three days' supply of meat, to be renewed at the post where I hoped to obtain the anti-corrosives.

Ishmah followed me, attached to his travail, and relieving me from the task of having anything besides my rifle to carry; and thus we travelled until a little after noon, when we came in sight of two Assineboyne lodges, on the bank of the Missouri ; here we sat down to cook, but of course, the Indians from the two lodges soon collected round us; consisting of three men-one of whom was a fine old fellow,-three or four women, and about ten or twelve young people of six years and upwards; they were very badly off for meat, and about starting to join their friends on White River; but on seeing us, of course, came to look for what they could obtain. Having but little meat for ourselves, we could not spare thern much; however, we gave one or two of them a little, after which one of the young lads came to me, and pointing in the direction of some high rugged hills 
at the opposite side of the river, told me he thought he could distinguish three animals-probably elk; but his report was contradicted by the others, who declared "Onijah," or "There is nothing." However, shortly after, the young fellow came back to me, and said, "My friend, there are now four things; and there could not be another unless they were alive: they must be animals." I thought the boy's reasoning so cogent that I sent another Indian to reconnoitre, who soon returned, declaring the boy to be right. This Indian then proposed that we should go in pursuit; but the men with me were tired, and would not undertake the severe task of scaling the steep, slippery, snow-covered heights. The poor Indian appealed most imploringly to me, and, clasping his hands, said, "My friend, I have no gun, but I will go ;" and, looking wistfully at a flint gun in the hands of one of the royageurs of my party, he asked him to lend it to him. I requested the man to lend him the gun (which he stood in no need of for the rest of the day, being with two other friends, the one armed with my double-barrelled gun, the other with a rifle); he did not, however, consent until I proposed a termination of the point at issue by a trial of strength between us, when he then reluctantly resigned the $\mathrm{M}^{\prime}$ 'Adamizer into the hands of the delighted Indian. At this juncture the old man leaped up, exclaiming, "And I will come, too, to bring home the meat." We then set off, all three, to cross the river: arrived on the opposite bank, we found the ascent very difficult, both on account of the nature of the ground and the steepness of the wild, rugged hills, with their intervening hollows filled up with avalanches of snow. I had not much time to contemplate the extraordinary scene around me as I waited a moment to draw breath after the first two or three steeps; but observed the wonderful peculiarity in this grand scenery, revealing every here and there, as a field of snow had 
slidden down from a torrering height, pinnacles of bright red clay, formed in mounds, minarets, and tall, slender, spire-like Gothic steeples, many of them striped with blue bands. The combinations of colours in this wonderfully strange scenery was heightened by the effect of an evening sun shedding sparkling rays over crystallized patches of the snow which had fallen from their dizzy heights. However, on we pushed over the steep, slippery red clay, rendered still more difficult of ascent by the constant drip of water from snow, which rested on many grass-capped heights. On reaching the extensive plain of one of the hills, we saw the animals we had been in pursuit of, standing not one hundred yards from the ledge on which we had clambered. They proving to be four blacktail bucks, I drew up my rifle, but on pulling the trigger, the cap alone exploded, the noise of which alarmed the deer, who started off, leaving us in despair of ever seeing them again. I was much surprised at the result, and adopted the best remedy; cutting a little peg of wood with my knife from my loading-stick, I hammered it into the pillar, then putting on a cap, I succeeded in discharging my rifle, loaded again, and resumed the line the deer had taken. After we had followed on the tracks for some time, we came in sight of them at a very long distance off, midway on the ascent of a range of hills separated from the height on which we trere standing by a wide ralley filled by avalanches of snow, a passage over which would have engulfed ns. What the exact distance between myself and the deer may have been, I cannot exactly say; but measuring with my eye,- which then was pretty well trained to calculating distances, - I considered them about a quarter of an English mile from where I stood.

I consulted the Indian, who assured me-as the wind was-it was almost impossible to go round all that distance, which involved a clétour of three miles, at the 
very least, in order to head up the valley, even if they would so long remain on a ledge of bare cliff where no feeding, or other inducement, was likely to detain them. Reluctantly I drew up my rifle and fired; the Indian then seizing me by the arm, declared he saw the shingle splinter in line of the deer I fired at; and, stretching his arms to their full length, said, "My friend, you were that too low down." I put in as much powder as I could venture, without risking the bullets "tripping," and wrapping a rather thicker leather patch than usual, I thus drove the tight-fitting ball down for a second shot. The Indian lay along the ground to look under the smoke as I discharged the second shot-aiming very high. He now assured me that he saw the stone crumble one arm's length lower than the feet of the same animal. Although I thought him a good deal indebted to his imagination for these announcements, yet I nevertheless loaded again as before, and on seeing a spot on the cliff, right over about ten feet above the deer's back, I raised my rifle this time, aiming as if to strike this-which happened to be very well defined on the cliff; I firedthe deer now made a start to spring forward, but slipped down backwards, and commenced moving for some time in a retrograde direction. The moment the others observed that their companion was injured, they dashed off along the ledge a little way, and out of sight over the mountain, leaving their wounded companion, who soon stood still. The Indian got greatly excited, and begged I would allow him to go alone after the wounded deer, and that I would remain for a land-mark for him while he started off to head the valley, saying, "My friend, it's your deer; I only want to go and kill him: I am sure of him, he can't run away." I gladly consented to his plan, and soon lost sight of him. I lighted my pipe, and anxiously araited his re-appearance on the brow of the opposite range ; at last he came in sight again, run- 


\section{LARPENTER'S POST.}

ning all right for the spot; and in about three-quarters of an hour from the time he started, he re-appeared, and having attained the ledge of shingle, was rapidly approaching the object of his pursuit. The deer fell in attempting to escape him-rose again; but fell to rise no more, as I saw the final puff of smoke issue from my companion's gun in the distance.

Following the line of the hills, I at length reached the spot, when I found the Indian araiting me, having skinned and cut up our prize. Shortly afterwards we were joined by the old man, and dividing the load of meat into three portions, we turned our faces homeward, descending with difficulty the "Mauvaise terre", as these hills are termed in the parlance of the country. We re-crossed the ice, and reached camp some time after night-fall. Our arrival was the signal for a grand feasting; a fire was lighted in the centre of one of the lodges, and cooking commenced; we all then sat round the fire, and most astounding powers of consumption and digestion were exhibited that night; for our small party not only consumed the whole blacktail deer, but even all the meat with which we had been provided for our journey by 0 wen previous to our departure. The greater part of the night was spent in feasting; and next morning we resumed our route; camped an hour before sunset, and, after a fruitless attempt on my part to stalk up a buffalo bull, went supperless to bed. Next morning was very fine; we rose early, and reached Mr. Larpenter's post late in the evening. This was a very miserable hut, and the supply of dry meat with which he and his companions were provided so small, that I made but one day's halt. I obtained a plentiful supply of caps from the opposition traders, who lived very comfortably, having had abundant opportunities of laying in a store of buffalo-meat by purchase from the Indians in the early part of the autumn. 
These traders were about to send a despatch back to Martin's post, so that their messenger and I travelled together; we were plentifully supplied with dry meat, and therefore were not delayed by being obliged to stop on our journey in order to hunt: and, finally, before the termination of the week, I was re-established in my old quarters again with Owen Mackenzie, to whom my fine supply of copper caps now rendered me doubly welcome.

After this the weather became so very fine, that nothing could persuade the few Indians still about us that we were not in the month of April. Frederick proposed going down with a couple of horses and an attendant to the Minitarée Fort; Peekay, the wellknown Indian, from whose squaw I had purchased Ishmah, proposed to go with him; and a couple of Indians having previously arrived, bringing me a most kind and hospitable invitation from $\mathrm{Mr}$. Chardon, who commanded at that post, I determined to accompany the party thither.

We accordingly set out one fine sunny morning, and though the weather at this treacherous season of the year is never to be trusted, the day continued so very fine that Frederick was quite overcome with the heat of the sun, and walked considerably in the rear, with his coat off, puffing and blowing like a grampus. We certainly formed a strange med̄ley ; first, Frederick and myself; then Peekay and squaw, with their dogs and travails among which, and drawing my. worldly goods, figured Ishmah conspicuously in the van; and lastly, the man in charge of the two poor miserable horses, packed with some articles of Indian trade, such as blankets, knives, vermilion, and especially gunpowder, of which they were taking the Minitarées a good supply, havirg heard that they were likely to be short of that useful article there. 
We proceeded as far as Knife River, when, Frederick being very tired from his walk of ten miles in the snow, we stopped to rest for a little time, and then proceeded to walk across the Grand Détour.

The Grand Détour is a sinuosity in the river, forming a bend of about forty miles in length; but the chord, or, in popular words, the short cut, of which is hardly fourteen.

At the commencement of this walk, I reasoned with them on the inexpediency of attempting to divide the journey, and urged the terrible position we should be in if caught in a snow-storm on the prairie; but nothing would persuade Peekay that we were not in the month of April ; consequently the short cut was decided upon in spite of my remonstrances.

We had proceeded about four miles, when we came to a narrow thread of ice, where trro or three trees indicated a small frozen stream : but so steep was its bank, and so deep had the snow drifted into this cantee, that we had to cut the trees down with our axe, and bring them up on to the top of one of the numerous little hills which formed the range, and between which the snow had drifted to the inconvenient depth I have described. When we had brought up our wood and lit the fire, some cooked, some unpacked the horses, and the old woman superintended the dogs. At last, having arranged everything comfortably, and stowed by our sides the different articles of the trade, including the gunpowder, we fell to at our supper. Night was then coming on, and it began to rain slightly; but we brightened up the fire again, little knowing what was in store for us. Shortly after dark the wind veered round to the north-east, accompanied by snow, and at last it blew so hard as to oblige us to put out the fire, especially on account of the gunpowder. Owing to our exposed situation, the wind mercilessly drove sparks, 
and even lighted brands, whirling amongst us, turn which way we would, as the eddies of wind drove furiously down the gullies against our little encampment from all points of the compass. Old Peekay and his wife collected every blanket and skin they could muster. I seized my buffalo-robe and blankets, called Ishmah to me, round whom I put my arms, and hugging him close to my breast, shivered through the night.

Never shall I forget the horrible hours of suspense I passed, expecting every instant the feeling of sleep to overpower me, knowing the fatal consequences and fearing an inability to resist it. I found my faithful dog an invaluable friend, and really believe he was the means of saving my life; for I seemed to feel the caloric, as it issued from him, preserve my body from turning into stone. Day at last dawned, and the wind abated. We contrived to move to a less-exposed situation, where we lighted a roaring fire, and warmed ourselves, then renewed our journey, reaching the opposite extremity of the Grand Détour by nightfall.

Our supper that night was a very scanty one of dried buffalo-meat, the last of the provision with which Martin had supplied us. As for the unfortunate dogs that accompanied the Indian Peekay and his squaw, they, poor wretches, had not eaten a morsel for weeks; and so awful an array of starved spectres never were seen.

The day after we reached the end of the Grand Détour was very fine; but although we passed over some likely country, I was unlucky, and could not find any game for some time. At length, one of us espied an old buffalo bull in the distance, and I determined to start in pursuit of him, although be was a very great distance off.

As I was adjusting my snow-shoes and girding up 
my loins, old Peekay lighted his long Indian pipe, and waved it torards the four points of the compass, making medicine; he then threw himself down on the ground, and uttered aloud the following words, as near as I can recollect Frederick's repetition of them to me ; for by the time he had smoked his pipe, or commenced addressing the Great Spirit, I was already a good step on my way. "O Great Spirit, you see the state we are now in; we have no meat, neither myself nor my squaw, and our dogs are sinking for want; we shall lose all our property, for the dogs are too tired to drag it any longer! 0 Great Spirit, help us therefore, and bring us some meat." His prayer ended, the old fellow Fent along the edge of the timber skirting the river, while I was far ahead trying to stalk up the bull, which I had hopes of succeeding in doing, on account of the inequalities of the ground where he was lying. The walk, or run, was very severe ; but after taking a great round to avoid giving the animal my wind, I succeeded in getting within 200 yards of him perhaps, when, unfortunately, in one of those fitful gusts of wind which broken hilly ground always renders so treacherous and uncertain, the bull scented me, never stopped for a moment's look, but wheeled round and dashed off as terrified as if I had been close to him. I could not blame myself for the contingency, and consoled myself with the reflection of there being fortune in hunting as well as a fortune of war. I had watched the bull's movements for nearly a mile as he ran headlong from me, when what was my astonishment at beholding a faint puff of smoke issue from a little thicket of willows in the horizon. I heard no report; but a careful eager look satisfied me that the bull had fallen. I hurried off to the place as fast as I could, and found that old Peekay, who had not fired a gun or killed game for many years, and who was, in fact, an infirm old 
man, had been walking through those very willows alongside of which the bull had shaped his course, when the animal passed the old man so close, as to enable him to send his ball through the heart at a distance of not more than ten or twelve paces. This was a most extraordinary combination of chances, -if chances they may have been called, - as the buffalo had a whole hemisphere of prairie over which to escape from me, and nothing at all calculated to induce him to make for the only point where destruction awaited him. It seemed as if the poor old man's prayer had been heard, and meat had been sent him at his utmost need.

We camped, quietly cooked, ate, and saved some meat for the rest of the journey, which we were unable to continue that day, as our unfortunate dogs so gorged themselves on the carcase of the bull, that when we harnessed them they actually lay down and howled; so on their account I was not sorry for the day's rest.

On the 1st of April I reached Fort Berthold, the trading post of the Minitarée Indians, very late at night. A slight thaw having commenced that day, rendered the passage of several creeks and ravines very dangerous, particularly for the horses. However, we arrived at last. Frederick and his man betook themselves to the wooden lodge of their fellow-traders, and I availed myself of Mr. Chardon's hospitable invitation to the fort. 


\section{CHAPTER VIII.}

Mr. Chardon.-Boucharville.-Geese put their heads together.-Ice breaks up.-A Cold Bath.-Arrive at the Fort.-Preparations.An Afternoon's Hunt.-Elk shows Fight.- Shot at Sundown.Hard Work.

I FouxD poor Mr. Chardon very ill, with a violent attack of rheumatism; but my arrival cheered him very much, and what little news I could bring him of his friends at Fort Union and the White River posts was very acceptable.

The Minitarées are a noble, interesting people. 'They are most absurdly termed Grosventres by the French traders, there being not the slightest foundation for branding them with that epithet.

From this time, with the exception of one fall of snow on the 4th of April, the weather began to wear the aspect of spring; and the breaking up of the ice on the river was daily expected, as in some places it had become rotten, and was no longer deemed sound enough to bear horses.

April 6th.-Boucharville, one of the most celebrated of the hunters and trappers of the Indian regions, came into the fort. The poor fellow had been most unfortunate; he had, in an untoward hour and under the influence of his evil genius, entered into a project of trapping wolves, foxes, mink, \&c., during the winter, and had established himself-together with two other companions-on a lake, about forty miles north of the post; but the winter having been more than usually severe, he lost his horses, and made by no means a successful hunt; besides which, he had all his traps stolen by Indians, and finally had a great escape of 
being taken by a war-party. I had a long conversation with him as to the best direction to take for a hunting expedition, and found he was thoroughly acquainted with the whole country. He was one of those quiet, patient fellows, that never put themselves into a passion or get flurried about anything; his appearance was very much in his favour-a manly, handsome conntenance, with large and deep-set blue eyes. He was dressed, as the hunters usually are, in elk-skin coat and mocassins, and deer-skin trousers, with a hunting-knife fastened in his belt, and in his hand he held his rifle, the sight of which he had accidentally broken off, and was deploring its loss, while endeavouring to supply its place with a small piece of lead, which he was whittling with a knife.

" $\mathrm{Ha}$ ! Boucharville, vous avez été malheureux, et j'en suis bien fâché."

"Oui, Monsieur, j'ai eu de la misère ; mes chevaux sont morts, et mes pièges sont volés, mais me voici enfin !"

After a long talk, I proposed that, as soon as the ice broke up in the Missouri, we should start off on foot back to Fort Union, making nearly straight across the prairie instead of following the sinuosities of the river, as I had done in my winter journey ; and we proposed, when we arrived at Fort Union, to take my horses and proceed on horseback up the Yellow. Stone River,intending, with the proceeds of our hunting, to descend the stream again in boats made of bull-hides. He liked the project, and so it was made a bargain. $\mathrm{He}$ was married to an Indian wornan in the village; so he borrowed a horse, went back to the lake for what few furs and property he still had, and returned home to the village to await the breaking up of the ice. About this time poor Mr. Chardon became worse: the rheumatism had attacked him very severely in both legs, 
and he was unable to stand; but I never saw a man more patient under suffering or more grateful when any one relieved the wearisome, dreary hours by sitting and talking with him.

The snow now began rapidly to pass away, and the smaller rivers and springs were open; ducks, geese, outardes, and swans came hovering over our heads. I had again recourse to my Trulock, but, alas! shot was not to be had; so I was obliged to make it as well as I could; first I tried pricking holes in a card, fixed in a small wooden frame, and pouring melted lead upon ittaking care to keep it perpetually in motion, by shaking it backwards and forwards.

But I found the following a better plan; i.e., to beat the lead quite flat, and cut it into little bars, about seven-eighths of an inch square, which we divided across, so as to form little cubes one-eighth of an inch every way. These we made as like grains of shot as we could, by putting them into a small metal boiler in the kitchen of the fort, and rolling them round and round with a smooth stone along with some ashes. With this very imperfect substitute for shot, I contrived to kill some ducks and geese. The latter were very difficult to obtain, as they always settled in exposed situations, where their long necks enabled them to see for a great distance round, and to be aware of the least sign of danger. One very windy day, and under shelter of a bank at a spring which supplies a little unfrozen pool, I contrived to crawl along the ground so stealthily that I came within thirty yards of a fine flock of wild geese. Their heads were all close together in an admirable line for a raking shot, as I lay on my chest in fear and trembling, chuckling with delight at my good luck; I stole the gun up cautiously to the front, and a fine raking shot I made. I did not stop to count how many I had mowed down with the first discharge, but fired the second 
barrel at one on the wing as he rose, knocking him over by the side of his companions. I found I had floored six at the first shot, and having picked them up, and the victim of my left barrel also, walked home in triumph with seven geese on my back, which proved a very grateful accession to our tough and scanty supply of meat in the larder: they all agreed that the geese in this instance had put their heads together to some purpose!

The 17th of April was a memorable day. About daybreak the ice broke up on the Great Missouri river; the explosion, as the water burst the rotten mass upwards, was like distant thunder. We rushed to the high bank on which the fort is built, and from its gate watched the various-sized packs of frozen blocks floating by, roaring with a splendid sound as mass after mass passed onmard forcing aside all resistance, and sweeping everything before it. The ice continued to roll by for thirty hours, keeping up a continuous roarit was a beautiful and, to me, a very novel sight.

I now bethought myself of starting on my journey to Fort Union for my horses, and therefore engaged two more men to complete my party. One of these was Pérey, a stout, active French Canadian; the other was a French half-breed named Paquenode: these I required in order to keep the camp, mind the horses, and cook, while Boncharville and I hunted. I also hired a horse belonging to one of these men, which enabled me to bring kettles, blankets, buffalo-robes, and, in short, to travel very comfortably. We took with us a small supply of dry meat, some coffee, a little bag of biscuits which Mr. Chardon gave me, and a large quart-bottle full of molasses to sweeten our coffee. This hung from our pack-saddle, and-wonderful to relate-notwithstanding all the ricissitudes of the journey, and the incessant and sometimes violent oscillations to which it 
was subjected as it swung from the saddle, the contents lasted us for the entire journey!

During our march we had frequent opportunities of procuring egors from nests of the waterfowl, which begin to lay at this season of the year : they proved a great treat to us, particularly as the supply of dried meat we had brought with us was very small; so much so, that both meat and eggrs failing, our rations were reduced on the fifth day of our journey to one biscuit each.

Early next morning we were passing along the side of the river, very hungry, and making a short march with the intention of hunting in the afternoon. Pérey carried a double-barrelled gun loaded with buck-shot, and was walking near the pack-horse, Ishmah and his travail following me, when we were astonished by the sudden appearance of four antelopes climbing up the bank close at hand. Oring to the steepness of the bank, they did not come in sight of us until they had reached the summit; the moment they did so they wheeled round, but not before Pérey fired and shot one, which rolled down the bank into the water, and was carried down the stream. Boucharville and I tugged at our gun-covers; his he could not remove quickly enough; I tore away the thong of mine-which had run into a knot-with my teeth, and cocked my rifle. By this time the other three antelopes were swimming away in the broad stream; a little eddy in the rapid current turned one of them broadside to me; I fired, hitting the animal between wind and water, behind the shoulder, -its head drooped, as, floating dead on the surface of the water, it was carried down the stream after its companion. Pérey then performed a splendid feat; he ran down the side of the river far enough to enable him to undress, - which he partly did in running, -jumped into the half-frozen water, along which the blocks of ice were still at intervals coursing, striking 
out boldly, laid his hand on the first carcase, then with great exertion reached the second as it floated by, and brought both into the bank: this was the more fortunate, for half a minute more would have swept them past the bend into the rapids beyond where the scene occurred, and involved not only the loss of our game, but a considerable risk to this brave fellow.

The two antelopes afforded us quite a sufficiency of food to last until our arrival at Fort Union, which we reached early on the ninth day after our departure from the Minitarées.

Arrived at Fort Union, I found things in a sad state; the hunters of the fort had been twice out for meat, and could find neither buffalo, elk, nor deer; one of them, Smith, an' excellent hunter, had wounded an elk, and in pursuing him through the timber had lost his mule, which he had brought out with him to bring home the meat. The Indians, who had congregated about the fort, of course were starving; all being afraid to cross the river and hunt up the Yellow Stone, for fear of attacks from either Blackfeet or Sioux. As to the points about the fort, my brother-sportsmen can well fancy how thoroughly thrashed they must have been by that time with the two white hunters hunting for the fort, and a bevy of Indians, all likewise eager in the pursuit, and depending upon their exertions for their very existence. The latter were in such a state that the traders had actually threatened to fire on their own Indians, to keep them from rushing into the post! The dried meat, with which the fort is always stored in case of game failing, had been badly saved the year before, consequently was unfit to eat; notwithstanding which, they gave one excellent meal to myseli and men, and afterwards I went out to inspect my horses left the winter before, now only two in number, and in very bad condition. My friend Owen had most kindly given me 
an order, allowing me the use of his splendid thoroughbred buffalo-horse, the finest I ever met with in America. He was a tall, powerful animal, with clean, sound forelegs, and grand haunches, very deep over the heart (so much so that it was difficult to prevent his saddle from slipping backwards), and on the whole, in good condition. So my stud now consisted of four horses, inclusive of the one I had brought up with me from the Minitarées.

The first thing I set about was to find the party in saddles, bridles, and halters; next, to lay in a store of powder, lead, and copper caps, together with three kettles and four tin mugs, besides a fair supply of coffee, sugar, and salt. A hatchet and two beaver-traps completed our equipment, and having set out all these our worldly possessions in the yard in front of the post, and counted over everything carefully, we proceeded to saddle up, Mr. Denig (who was now in charge of the fort) urging us to make haste out of the way as soon as possible, not half liking the prospect of having to supply us with another meal. We divided equally amongst the four horses, by means of ingeniously-contrived thongs on the pummels and cantles of the saddles, the responsibilities of the various stores, each man carrying his own tin mug with him. The smith then brought out Boucharville's rifle, which he had properly sighted, and taking up our guns, we bade good-bye to Mr. Denig and the inmates of the fort, and rode away.

We now found ourselves once more thrown upon our own resources in a country from which the game was almost driven away; but Boucharville and I were well aware, that if we could once cross the Missouri below the mouth of the Yellow Stone, and then proceed up the left bank of that river, we should, before we had traversed ten miles of country, be in the midst of plenty. But here we were unable to cross! the water still intensely 
cold, three of my four horses in such wretched condition, that I dreaded the idea of transporting them over with such precarious assistance as that of a raft, particularly when only constructed of drift-wood, and with the very insufficient means which our skill and resources could supply. However, I was determined to make the best of it, and we rode down to the next point in the river, and encamped nearly opposite the mouth of the Yellow Stone. The weather was so windy that we gave up all idea of taking our horses across it for at least two days more ; so, as soon as we had found good grazing-ground for the poor animals, Boucharville and I set out to hunt in the point where we were camped. We.were both very tired; a previous journey of eight days' marching, our disappointment of the rest a couple of days' lounge in the fort would have given us, and, above all, the dread we had of making our poor horses cross by means of any raft that we could construct, all combined to put us out of spirits. Very unexpectedly we got two shots at deer that day, notwithstanding the scarcity of game. Boucharville broke the leg of one deer ; but did not get him, and finally he rent to bed, having had nothing more than a cup of coffee for supper. While we were hunting that afternoon, Paquenode and Pérey had constructed a very comfortable little hut by driving a framework of sticks into the ground, taking a large piece of lodge-skin for a cover, and piling up great pieces of bark for the back and sides of this notable edifice. So spreading our robes and blankets on the ground inside, with the saddles as pillows for our heads, we lighted a good fre outside at our feet, and made ourselves comfortable for the night. Our house was constructed in good time, for we had fortunately anticipated a fine domfall of rain. It continued to pour all night; but wehardly suffered any inconvenience from the rain, and on the whole, with the exception of having nothing to eat, were 
very comfortable. After all, we could not complain, even in that particular, having had at eight o'clock that morning a splendid breakfast of elk, fat salted buffalotongues, coffee, and, what is rare luxury in that country, delicious bread.

Early next morning Boucharville started off to hunt; but I remained behind, doubting very much the possibility of procuring any meat where we were. Before he departed, horrever, I charged him to return shortly after noon to camp, when I proposed saddling the horses, and setting off for a fer miles together down the river to a very fine point I kner, having hunted it successfully the previous winter, before my first departure firom Fort Union. I then lighted my pipe, and afterwards went to sleep. By-and-by the day turned ont fine, and we proceeded to dry our robes and blankets, wipe the saddles, clean the bits, and the few stirrup-irons (for we had but five to four saddles) that we possessed. My own saddle I had complete, it being an excellent one that I had brought up with me in the autumn; but the other three boasted of but one stirrup-iron apiece. I subsequently learnt, under Boucharrille's tuition, to make admirable wooden substitutes for these while on the prairie.

Soon after two o'clock, Boucharville returned to camp without having had a single shot; so, in accordance with my plan of the morning; , we brought in and saddled the two best horses (i.e. Mackenzie's and my old mare), and rode three or four miles along the prairie down the river to my favourite point. This was a very fine rood, about nine miles long, and from four to five deep, interspersed with lovely glades, and beautiful feeding-grass for deer and elk. "We continued riding alternately through these and thick willows, till, on emerging from a copse of the latter, we came in sight of a band of some fifteen or trenty wapiti feeding in a large glade. We immediately fastened up the horses, and crept noise- 
lessly on foot under cover of the brushwood towards the spot. Arrived at the utmost verge of our friendly shelter, we had the mortification to find that we were too far to risk a shot, there being fully 230 yards between us and them. We held a council of war, and after some hesitation, determined to steal back to the horses, ride some way round, and come upon them from a direction at right angles to the one we had just tried, where we could see a clump of rose-bushes, which we fancied considerably nearer to the elk, and which we intended to try and reach by approaching from an easterly instead of a northerly direction, we being then between them and the river. Accordingly we crept back on our hands and knees; nor did we get up and run towards the horses until we were well out of sight of the wapiti. We then mounted and rode half a mile or so round to the east, when having again tied up the horses, we crawled as before upon our hands and knees, and reached the extremity of the rose-bushes unperceived. Here there was a large tree, behind which I could stand up quite screened from view of the elk, while Boucharville knelt on one knee at the edge of the cover, a position in which he could shoot very well, for he used to make a rest for his rifle, by sticking his ramrod and loading-stick firmly into the ground across each other; I, who never could shoot well from a rest, preferring to stand up. We were now about 150 yards from the nearest of the band. I chose a fine old stag, while Boucharville, with an eye to superior meat, singled out a doe. We drew up our rifles slowly, and both shots went off together. 'The smoke hung heavily for a second or two; when it cleared away, we espied one of the wapiti lying down. 'I'he next instant down rolled the stag also. We agreed to advance at the same moment, lest one or other of the animals should be able to get up and escape. On coming near my stag, he struggled to rise, but, unable 



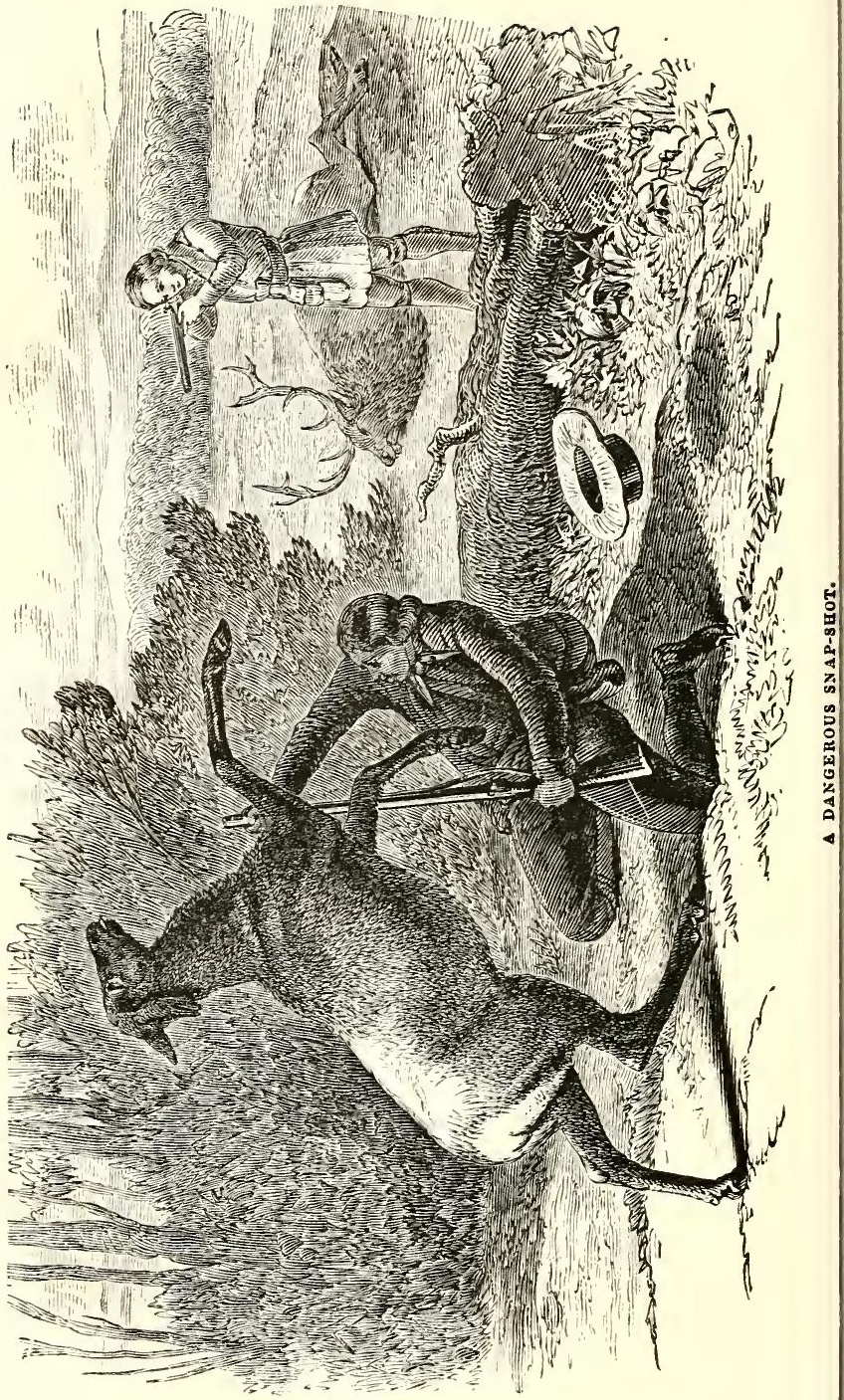


to gain his feet, rolled back again. I looked towards the other, when what was my surprise at witnessing a regular combat between Boucharville and his wounded elk, now transformed into a very formidable antagonist. Springing on her haunches, she was striking furiously at him with her fore-feet: one hoof missed him, but the other fell on his rifle, which he held up for his protection, and smashing both his ramrod and his loadingstick, beat him down on his knees. Rising a second time, she was about to repeat the attack, when my bullet caught her in the side of the head behind the eye, and with a splendid bound she fell lifeless on the broad of her back. I had made a quick and necessarily a rather dangerous shot, but I was in luck that day. "Sacré enfant du diable!" exclaimed Boucharville, as he halfrose from the ground, but looking at nothing till he had satisfied himself that his rifle was uninjured; "mais qui l'aurait cru? Ma foi !" continued he, laughing, "j'ai bien échappé, une biche à un côté et une balle à l'autre!"

Leaving him to cut up the meat, I ran off for the horses, which I brought up. The day was beginning to wane, and we had some way to go home to camp; so we made all haste to pack the horses, and placing the heavy hides under us and over the meat, we climbed up on the poor brutes, and jogged homerards. I still remember well the beautiful sunset I gazed on that evening as my horse almost staggered along under his unmerciful burden. At length the long-drawn shadows in our wake faded quite away, and the sun disappeared behind a ridge of hills to the westward in a splendid sheet of gold. All at once, in strong relief against this light, I saw some deer playing and running sportively backwards and forwards, appearing and vanishing by turns on the brow of the hill. I left my horse to graze, and stole nearer on foot, quite invisible to them upon the 
dark prairie. When I came within shot, one deer was standing nearly broadside in bold and clear relief against the amber sky; drawing my rifle slowly up, I found I could catch a glimpse of the sight between the deer's belly and the hill, and again above his back. I repeated the movement several times, as, unconscious of danger, the animal stood perfectly still; and having finally satisfied myself, raised my left hand once more, and on losing view of the sight against the deer's body, pulled the trigger. It was now so dark that I could see nothing more. I ran up the bluff, and soon discovered, by his frantic floundering, a jolly fine old buck with a bullet through his brain. I shouted to Boucharville, who was astonished on coming up to find me standing over my prize, skinning away as hard as I could. With his assistance the necessary operations were soon concluded, and clividing the meat between the two poor already overladen horses, we jogged on to camp; I in a high state of delight, Boucharville not half relishing my having fired a shot so near camp (then not two miles distant), for fear of its attracting the notice of prowling Indians. We reached home late, and welcomed by the plaudits of my two hungry horse-guards, who had everything in readiness for cooking dinner; we feasted till far into the night, chatting over our adventures.

Before turning in for the night, we determined that early next morning we would take all our surplus meat to the fort, and exchange it for divers things we yet wanted to complete our equipment. All slept sound, with the exception of Boucharville, who never closed his eyes for fear that Indians having heard my last shot, might track out our camp and steal the horses as they were grazing about. Morning, however, dawned cheerily, revealing them to our view, all safe and sound. It was a lovely day; and each, as he tightened his belt, 
felt that he had much to do, and was well up to his work. We packed two horses with as much meat as we could possibly spare, and, mounting the other two, Boucharville and I rode to the fort, leading our beasts of burden. Breakfast was ready when we arrived; and we revelled on bread and fresh egogs (the hens laying very well, although fed, like the pigs, exclusively on meat). Mr. Denig after breakfast gave me, in exchange for the venison, an excellent four-oared skiff belonging to the fort, some awls, needles, strong thread, and fishhooks. The skiff was exactly what I wanted to take the horses across the river, which in these parts was nearly half a mile wide; and, delighted with this arrangement, I sent Boucharville and the three horses back to camp, with directions to send up men to take the skiff down the river to the fittest place for crossing. As soon as it was done, we commenced the arduous task. Owen's horse I took first: he was a fine, thoroughbred fellow, and swam in gallant style; the mare not so well ; and the last proved an exception to the generality of horses, in refusing to swim altogether. I held his head, however, above water, while my companions rowed with might and main, and after considerable exertion and loss of time, during which we made great leeway down the stream, we succeeded in getting him over. I thanked my stars that we crossed in a good skiff; and am quite sure that had we attempted to take the brute across with a raft of our own construction, he would certainly have been drowned, and we might very probably have been obliged either to let him go adrift or to have shared the same fate with him. We were not long in returning and bringing over the rest of our traps; and that done, I immediately proceeded to bury my valuable boat under the willows on the south bank of the Yellow Stone, close to the junction of the Missouri ; for having had some experience of the appro- 
priating propensities of the younger Indians, and rightly judging that they would soon be in that neighbourhood on their way down the river for their spring trade with Fort Union, I thought it prudent to put my property out of their reach; and so hid it carefully in a fine sandy deposit, where we could recover it again without much trouble.

\section{CHAPTER IX.}

Hunt on the Yellow Stone.-Grosse-Corne Hunting.-A Beautiful Camp.-Beaver.-Good Hunting Country.-Cat Fishing.-Skinboat Building.-Tailoring.-Crow Indians.-Descend the Yellow Stone.-Surprise a Crow Camp.-Return to Fort Union.

Next morning we commenced our hunting excursion up the Yellow Stone, starting at a very early hour, and found game more and more abundant as we proceeded from the mouth of the river, every now and then starting a deer, or coming in sight of a long continuous file of antelopes. These march in line, sometimes for several miles together, and, by imitating the movements of their leader, exhibit the most striking effects, resembling military evolutions: they simultaneously whirl round their white breasts and red flanks, like the "Right face!-Left face !" of a regiment on parade. Obedient to the motions of their leader, when he stops, all stop: he stamps and advances a step, the slight similar impulse waves all down along the line; he then gives a right wheel, and round go all their heads for one last look ; finally, he gives the right face about, and away "their ranks break up like clouds before a Biscay gale." Stately wapiti wandered on the plain, feeding not far from the willows, to whose friendly 
shelter in they crashed the moment we presented ourselves to their view. And as we approached steep frowning cliffs, overhanging the river, I saw, for the first time, the wild sheep or grosse corne of the Rocky Mountains, balancing themselves, chamois-like, on the tops of most inaccessible crags, whither they had rushed on first catching sight of us. The grosse corne, or bighorn, partakes both of the sheep and the deer in its appearance, and in its habits resembles the chamois of Switzerland, being quite as watchful, possessing equal facilities of bounding over fissures, and clambering up similar inaccessible places. This wild sheep is stoutly built, and its feet are stronger and larger than those of the deer. The animal's light dusty-brown colour conforms to Nature's law, and resembles those shingly rocks to which it clings for protection; a very slight quantity of wool grows about the ears and neck, also about the knees; the rest of its coat consists of strong coarse hair, white on the rump, and tail tipped with black. Both the female and the male carry horns; those of the former resembling the little horns of a goat, only flatter, while those of the male are of a ponderous size; out of all proportion to the apparent strength of so small an animal, they grow somewhat similarly to those of a common ram, only vastly larger. I have measured some that curved more than usual, as much as two feet eight inches in length; the hollow part is capable of containing two quarts of water, and is twenty-three inches in circumference at the orifice. The cartilaginous processes on which the horns grow are very strong, and so also is the frontal bone, with which they form one mass, so solid as to enable the animal safely to fling himself on his head from very considerable heights. I was told that when some of these rams reach a great age, frequent instances have been observed of the horns curving in such a direction, as that their points re-grow 
into the animal's head, and thus terminate its existence ; of this phenomenon, however, I never myself was a witness.

Arrived at this range of hills, I immediately called a halt, determining to have a hunt after big-horn; and leaving my two men, Paquenode and Pérey, to make camp and look after the horses, Boucharville and I started after the sheep.

We found them very wary game, and almost impossible to approach; once I clambered to within fair shooting-distance of a ram, concealed from his view by a sheltering crag; but the moment my head and rifle were raised for aiming over this ledge of rock, he was off with one bound, disappearing down a fissure in the rocks, where I thought the animal would have been dashed to pieces. Unlike the deer, who will generally stand and gaze a moment, as if trying to make you out, the wild sheep is so shy and wary, as well as quick-sighted, that the moment he sees the slightest strange object above a bank or rock, he is instantly off.

I got, after much toil and difficulty, a tolerably fair shot at a ewe, but missed her, being blown by the constant climbing: These volcanic rocks and hills are very deceptive in their appearance; and their similarity causes much difficulty in obtaining an approach to any spot from a direction different to that from which you obtained the first view ; for, on descending and creeping round their bases, the rugged cliffs assume appearances differing widely from those which presented themselves from the preceding summits. At last, however, I succeeded in circumventing a fine old ram; and carefully and noiselessly we ascended the cliff commanding a view of our game, unconsciously standing about sixty yards below us, close to some stunted cedars. I pointed my rifle downwards, and as the echo and smoke of the shot rolled away, I saw that my bullet had broken his back, 
and sent him floundering below. At the report of the shot, two lambs bounded off, and Boucharville instantly started in pursuit of them, answering my remonstrances by declaring them to be such excellent eating.

I therefore left him to his own devices, and clambered down to my ram, which I had ample time to survey with great delight ; and so long was I observing his magnificent proportions, that I did not commence skinning and cutting him up until I heard my companion's rifle crack ; and, shortly after, a second report conveyed to my imagination what had been the probable fate of the lambs: however, I was satisfied, as I had not been a sharer in the murder of the innocents. So, knowing that Boucharville would most likely send me assistance from camp, I lighted my pipe, and, after a few puffs, lay down and went fast asleep ; from which I was arrakened by the arrival of my two horse-guards, who had come for the meat, which, together with the skin and horns, we took home to camp.

On our return, we found Boucharville busy roasting tro loins of lamb, and boiling more ; so, after stretching the ram's skin, I sat down beside him, and found the lambs, I must confess, much better meat than the tough old ram twe had just brought in.

Next day, feeling a little stiff from the effects of the grosse-corne hunting of the day before, we determined to stick to the moods and level country. Accordingly, Boucharville and I hunted up the left bank of the Yellow Stone. The scenery was splendid, the river being very circuitous and beautifully mooded; rosetrees, willows, and numerous and beautiful rhododendra were strewn over the plain in advance of the heavy timber. We returned late, bringing in the skins of two wapiti, three deer, and an antelope to camp, together with a portion of the meat.

After we had continued hunting and travelling for 
some days up the Yellow Stone, our skins and furs, naturally enough, accumulated so fist that we found, if we went on much longer at the same rate, we should be forced to leave some of these behind us on the prairie. Sooner, therefore, than lose these, I determined on looking out for the next favourable spot for a camp, and chose a beautiful site at the mouth of the Big Horn River, one of the tributaries of the Yellow Stone, and about 100 miles from its junction with the Great Missouri. The scenery at this spot was splendid, and at the termination of the point the grass was excellent. The green brushwood luxuriated all around, giving the whole region an appearance of being well cared for, so utterly did that spot differ from the vast wastes on the Great Missouri's banks. The woods were thickly stocked with evergreens and shrubs now flowering; the river rolled majestically along, and for some distance the beautiful grass which carpeted its alluvial deposit grew luxuriantly, without being rank. This plain was terminated to the south-west by high rocky, broken hills, almost inaccessible in some parts, where grosse corne abounded ; and finally, the crowning advantage in the position I had taken up was, that buffalo were to be found there also, one of my men, sent out to reconnoitre, having reported large bands feeding on the neighbouring prairie. The spring was now making rapid strides, and bringing up the young curly grass in great abundance. Stretching an awning of skins to the south, to protect ourselves from the sun's rays, which were now becoming a little too warm, we ranged out all our baggage, skins, and other trophies, and then set to work cleaning guns, mending mocassins, harness, \&c., which occupied the greater part of the day. In the evening Boucharville accompanied me for a short distance up the Big Horn River, where we were hunting, when he suddenly came to a halt, exclaiming, "Tenez, monsieur, 
il y a des castors ici, voyez !" and he drew my attention to a couple of trees of considerable size, cut down by the industrious little beaver, forming a dam alinost across the stream, and leaving me to contemplate this extraordinary monument of their sagacity, he rode back to camp for the traps. On his return, he set them under water in runs, which they had made by passing constantly backwards and forwards on their journeys to and from the water; as a means of enticing them, he smeared on the plate of the trap a stuff termed "Medicine Castor," consisting, I believe, of an extract from their kidneys, in approaching to smell which, the poor little beast springs the trap, and is victimized.

These industrious little creatures form their habitations of trees hewn down, and cut up into $\log _{s}$ with their teeth, cementing them together with branches and mud plastered with their broad tails, which they use as trowels.

Some years ago a tame beaver was kept at Fort Uniow. This animal, notwithstanding all the comforts of his abode in the fort, every now and then took a brilding mania into his head, used to cut and collect wood most indefatigably; and on one occasion, when he could not find wood enough for his purpose, was discovered cutting up the legs of one of the chairs into logs. During these periods of working, he used to sharpen his teeth from time to time.

The entrance into a beaver's hut is generally under water, and you will almost always observe two chambers, one constructed below, and the other high and dry above the water: bark is spread on the floor of the latter chamber, which is always kept scrupulously clean. Indeed the skill and intelligence displayed by the animal seems greater than that which instinct can dictate, not merely in choosing its timber, but also by cutting the tree down with its inderatigable little tusks, in such a 
way as to make it fall exactly in the direction it wishes, above the intended place of residence: so that, when it cuts it up into lengths, it can swim down stream, steering the logs to their destination.

Before breakfast next morning we went to visit the traps, and found a beaver struggling in each; one had been taken by the foreleg, which was fractured high up, the other was caught across the jaws. My companion put them out of pain by striking them on the back of the head with a stick. When I saw the helpless struggles of these poor intelligent little creatures, I was seized with remorse, and determined forthwith that there should be no more beaver-trapping.

As Boucharville and I subsequently were conversing on the habits and wonderful intelligence of the animal, he thus strikingly expressed himself: "Monsieur, ils sont une espèce de monde."

Fortunately for these little people, silk, which is now manufactured into hats, has proved an excellent substitute for their fur, previously so valuable; and now that beaver-skin has fallen from eight and nine dollars a pound to a dollar and one and a half dollar, ararice and self-interest will no longer ply the instruments of their destruction, and sweep the ingenious lictle population off their Western waters.

After breakfast Boucharville and I rent in quest of buffalo in the direction indicated by Pérey, who had, as above mentioned, been out to reconnoitre. We rode, each leading a spare horse. Boucharville took his rifle. to stalk them on foot, while I, anxious to test the powers of Owen's fine hor'se, which was now so much improved in condition, took my double-barrelled Trulock. for a run on horseback, intending, if possible, to pick out a barren cow, as they afford the choicest meat at this time of year.

We approached a herd of buffalo very successfully- 
thanks to intervening hills and the irregularities which the prairie afforded - and when about 400 yards from our game, hobbled Boucharville's mare and the two pack-horses. I then tightened the girths of my saddle, poured some loose powder into the right-hand pocket of my hunting-shirt, and waited quietly until Boucharville stalked up the nearest of the bulls. As soon as he reached a favourable position within shot, he fixed his temporary rest as usual, and after a deliberate aim, fired. I could see that the animal was well hit, from the convulsive start he gave, merely cantering a little way, and then stopping; the rest of the herd, on hearing the shot, looked up; but seeing nothing, went on grazing again. I remained concealed to let Boucharville have a second shot. Accordingly he loaded-on his knees all the time-and replacing his rest, selected another bull about 100 yards off. At the instant of the report the animal floundered formard, stumbled, recovered himself, stumbled agrain, and finally came thundering to the ground. The whole herd now rushed off at full speed, the corrs leading the van, and the bulls bringing up the rear, and last of all Boucharville's first victim, rapidly falling behind. It was now my turn; so putting a couple of bullets in my mouth, I gave chase, and galloping first up to Boucharville's wounded bull, shot him down on his tracks as I passed. Then, loading as I rode, I soon outstripped the bulls, and got alongside of the cows; but they were so thin and miserable, being most of them in calf, that I was sereral minutes before I could single one out. At last I spied. a barren cow that seemed to promise good meat, and, firing into her, wounded her, so that I easily separated her from the rest, and after griving her a couple of turns, passed and shot her with the other barrel.

I was now more than a mile from the scene of Boucharville's exploit with the bulls; but knowing 
that he would soon find me, I took off my saddle, tied my horse's fore-feet together with a strong soft band of ?eather, and, taking off the bridle, turned him loose to graze, and set to work to cut up my cow. She was in wonderful condition, with nearly two fingers' fat on the loin, surplising for that time of year. As soon as Boucharville had skinned and cut up his two bulls, he joined me, and we brought the three skins and most of the meat to camp.

The evening was beautiful, and Peekay and Paquenode had gone to fish; so leaving Boucharville to unload and look after the horses, I strolled down the bank of the river to see what sport they had had. I came upon them unperceived, and never was more amused. A very large timber snag, about fourteen feet long, and very thick, lay fast a little way out in the stream: to this they had waded, and, perched one on each end of it, were intently absorbed in their occupation. Their trouser's were tucked up to their knees, and as they sat squatting on their heels on the $\log$ in the most rigid silence, each eagerly grasping his miserable little rod with both hands, their long hair, which had got wet, and had been pushed back from their faces, sticking out behind, they looked exactly like trro famished cormorants on the watch ready to pounce upon any luckless fish that might pass up stream. I raded out, and stood behind them some time unpereeived, not a syllable being cxchanged between them. At last the silence was broken by my bursting into a fit of uncontrollable laughter, in which they joined most heartily, as soon as they recovered from the surprise I had given them. They had caught three very fine cat-fish, about two and a half pounds each, and before I left them they caught a fourth; upon which we all returned to camp, and enjoyed, for the first time, fresh fish, in addition to sood buffilo-meat and coffee, for supper. 
The cat-fish is one of the finest flaroured I ever ates firm, white, and very rich ; the men called it "barbue." It is a quaint little fish, like a miniature dolphin; has double fins, besides those on its back, and a preposterously long beard-like excrescence from each side of its mouth.

After supper $I$ called a council of war, and determined to set about building a boat, to convey our skins and furs to the mouth of the Yellow Stone; and accordingly, next morning after breakfast, we set to work. The boat was to be constructed of the skins of the two bulls stretched on a willow frame, which we accomplished in the following way. 'Two long and tolerably strong pieces of willow were cut, and lashed together to form a keel, about fourteen feet long; at about twenty inches from each extremity of this lieel a notch was made half-way through the rood, so that we could bend it upwards to form a sharp stem and stern to our boat; then, completing the skeleton of a punt, or rather of a flat-bottomed canoe, we fastened willow-knees at regular. intervals, tied tight to the keel and round the frame ; and cutting the head parts of the hides of the bulls low down on the neck, sewed them together with awl and sinew at that part; and while reeking, and before they had tince to get stiff, threw them over the ricker frame, lashing them on with elk-skin cord. While Boucharville and $I$ were busy at this work, my two men were occupied cutting all the meat up in large thin pieces, and drying it in the sun.

I Was at this time very badly off for clothes. My large winter grey woollen shooting-coat (or capote) was completely worn out; over and over again I had patched it with pieces of blanket, but still the rents were made worse, and at last it went utterly to pieces. I had, however, with me an elk-skin, which had been uncommonly well dressed by one of the men while I was at 
Fort Union; this I took and cut into a hunting-shirt with loose sleeves, sewing it up partly with buffalo sinew and partly with thread procured at the fort; the dressed skin of a small deer furnished the pockets in front, and it was subsequently ornamented for me with porcupine-work by some Indian women, on my return to the fort. The fit was not of much consequence, as my belt confined it round me. I found this a most effective hunting-shirt, for no brushwood could tear it; and it now hangs up among my other trophies as fit for service as ever. Although it was a simple thing in itself, to cut out and make the hunting-shirt, yet it took me three day's, inasmuch as I was obliged first to smoke the leather in order to prevent its shrinking and hardening like parchment, every time it got wet; next to cut it out without the help of scissors, and with my hunting-knife only; and, lastly, to sew the strong, tough material together without a thimble, which was very tedious indeed.

The day after my hunting-shirt was completed, I went in chase of grosse-cornes with Boucharville, and we killed a couple of ewes, in excellent condition. I was greatly pleased at coming within shot of, and unobserved by, a very fine old ram, who was standing among some stunted cedars in rough, rocky ground. T'wo exposed cedar-roots crossed above the surface in such a position as, from where I stood, to form a cross right against the fore-shoulder of the animal ; so, profiting by this mark, and arguing that if my bullet passed within an inch or two on either side of the point of intersection, it would be sure to strike a mortal part, I aimed right for it,fired, and on the smoke clearing off, perceived my ram bounding unscathed from cliff to cliff. I had the curiosity to go and examine the spot, and found, to my surprise, that one root had grown into the other, and that my bullet was buried deep in the wood at that 
very place, whence I cut it out with my knife and brought it home in my pocket. We lived like fightingcocks in my little Yellow Stone camp: I used every day to sit down to several kinds of meat, besides fish. One day we actually supped on buffalo-beef, elk-meat, venison, antelope's-liver, and wild mutton, besides the luxuries of cat-fish and marrow-bones. Coffee and sugar were lasting very fairly, and so was the salt; but, plenty as the meat was, I did not allow it to be wasted; and, as we had more than we could carry away in our skin boat, I determined to build a second, so as to convey it all to Fort Union.

My nether garments, also, were by this time in a sad state of dilapidation, although they had been so frequently pateled with leather, so that it was very dini cult to say of what material they had originally consisteit I disliked very much the idea of undertaking the con. struction of a pair of trousers, as I had found the hunting-shirt such an arduous task, and therefore deferred the evil day as long as I could. One fine morning, however, I went in pursuit of a very fine wapiti stag, which, with several others, was feeding in some brushwood, about a mile and a half from camp. As I was crawling towards him on my hands and knees, a sharp stake caught me a little below the knee in one of the numerous rents which ornamented my garments, and neatly removed the entire protection of my right leg. A brother sportsman can exsily suppose that I did not allow the loss of a gaiter to check my progress, but stalked up my elk, got a shot, wounding him very severely, and after a hard run, killed him; but so far from the spot where I had lost my leg-cover, that I made no attempt to find it again; and had no other resource but to make myself a new pair of inexpressibles with all possible despatch. By Boucharville's advice, I determined to go in quest of black-tailed deer for my 
material-their skins producing the leather best adapted for trousers. So next day, we mounted our two best horses and followed up the river for a few miles until we came to La Rivière, a little tributary of the Yellow Stone. We took the traps with us, but did not see any very recent signs of beaver. I fell in with an enormous Virginian doe and got quite close to her in the wood before she saw me. She was about the size of a fullgromn Scotch hind, and was nearly as large a specimen as the giant buck I killed one night in Arkansas; but my hor'se was so restless that I could neither get down unobserved nor fire from his back; and so she escaped.

We continued along little watercourses, and trying the brushwood on the hills, till Boucharville got a shot at a black-tailed buck, but missed him, as I did also a doe. After a good deal of hard work, we shot a blacktailed doe each : the meat was not very good, so we did not burden the horses with it, but brought the skins to camp. On the morrow I occupied myself in dressing them, with Boucharrille's assistance, and the following day finished and smoked them, and began to cut out. The celebrated Rout, of Portsmouth, who was once known to affirm that he passed sleepless nights over the cutting out of trousers, could not have taken greater pains than I did with mine; still I wasted the cabbage to such an extent, that before the completion of my work; I had to sacrifice another deer at the shrine of the Sartorian god.

In this life, I believe, it is impossible to realize half our wishes and expectations; one cause of disappointment always remained to render incomplete the enjoyment of the splendid sport I revelled in every day. If I wished to shoot from horseback, a ride of a few miles afforded me most splendid runs; if I wished to hunt wapiti, the points on the river contained them in just sufficient abundance to afford that amount of toil and 
labour without which nothing that is obtained is duly appreciated: of deer I had a considerable number; black-tailed deer I could always obtain by going a few miles' distance to look for them; the grosse-cornes I could sometimes see swinging, as it were, and balancing themselves on tops of the cliffs as I sat in my orn camp ; antelopes, too, were constantly to be seen, and many a prowling molf I nailed by disposing offal in places easily approachable ; or, should I feel lazy, and merely inclined to practise my rifle-shooting, in order, as they say in Ireland, "to keep my hand in," I could always find lots of pheasants and one or two rabbits. Notwithstanding all this, one species of sport yet lacked me-I could find no grisly bear. I hunted long and carefully for them; but, strange to say, the whole time I was on the Yellow Stone, I did not meet with a single one. I had, it is true, fallen in with their tracks, which were quite unmistakable, and these, too, frequently quite fresh; and had often ridden or walked tracking them for long distances, but almays to some watercourse where I lost the foot-prints among the shingles, or on some substance too hard for me to trace them any further.

'The camp was now full of meat, and my men had occupied all their leisure hours, and most of the time while I was hunting and tailoring, in preserving it. The season was now late in May, and I determined to return down the Yellow Stone to Fort Union, there to take up the skiff that we had buried at the mouth of the river, and to row down from thence to the Minitaree Fort-about trro hundred and eighty miles down the Missouri ; my grand object being, if possible, to make another hunting-trip, and try my fortunes in grislybear hunting before the return of the American Fur Company's stermer in July.

While I lay in camp one morning, turning this scheme orer in my mind, Boucharville came running in to me, 
and said, quietly, "Ma foi, monsieur, voilà les Peaux Rouges!" I immediately jumped up and discovered some Indians on the opposite side of the river. Our horses were not far off, and both they and Pérey, who was with them, were hidden from the Indians by the willows of the point on our side. The latter were evidently not endeavouring to conceal themselves, but were running to and fro on foot and on horseback. They were so far off, Boucharville could not distinguish whether there were any women amongst them or nota point I was most anxious to determine, as that would have satisfied us as to whether it was a mar-party or not. I felt, however, tolerably convinced that they were Crows, and in all probability the party for the spring trade at Fort Union. They might possibly have been Blackfeet, and consequently a war-party; in which case we should have had a fight for it, had they seen us. At this moment Boucharville and I were immensely amused by Paquenode, one of my men, rushing into camp, in $a_{3}$ state of extreme terror, with his eyes starting out of his head: first he begged a horise in order to gallop away and escape; then he implored for the bull-skin boat to try and get off down the river. The more we laughed at him, the more he stamped and cried, until at last the scene became so ludicrous, that I thought Boucharville - who was in general the gravest, quietest fellow in the world-would have died of laughter. Pérey then came in and could not help laughing too; he had caught sight of the Indians on their first appearance, and had cleverly taken all the horses and fastened them in the willows, and had afterwards gone out through the point on foot and reconnoitred. He pronounced them to be Crows, but he was furious with Paquenode, who, in his terror, had actually seized on Mackenzie's splendid thoroughbred horse, and, but for Pérey's violent interference, would have been at that very moment galloping over the 
prairie. However, although the probabilities were strongly in favour of their being Indians of a friendly tribe, I determined, if possible, to remain concealed, in the hope that they would pass us by unobserved; as they were most likely young reckless savages, very anxious to distinguish themselves by making a "coup," and who by hanging about our trail to steal the horses, might give me some trouble. My plan succeeded perfectly; and notwithstanding the Argus eyes of so many Indians, we escaped unperceived, which I was glad enough of; for, although some Indians individually may be very tractable, yet collectively they are a great bore, and the constant begging to which they subject one is anything but agreeable.

Boucharville and I went out after the bulls as soon as they were well away, in order to get materials for a second boat. We killed one each, very large, old specimens, and set to work at once at our new canoe, which we completed late the following evening. Next morning I despatched Pérey and Paquenode with the four horses back to Fort Union, across the prairie, a distance of not more than ninety miles, as the crow flies. This journey I rightly calculated they would perform in three days without knocking up the horses, which, by this time, had had abundance of rest, fine pasture, and fair play. We gave them plenty of meat for the journey, a kettle to boil it in, and in fact everything they required. Boucharville and I determined to descend quietly by water; and although this was by far the longest way, being nearly three times as long as the land route, yet the rapidity with which the Yellow Stone flows, almost made up for the difference.

The first thing we had to do was to find driftwood suitable for making us each a light paddle. In this we soon succeeded, and having packed the two boats, we placed ourselves, one in the bow and the other in the 
stern of the foremost boat, having the second lashed on and towing in our wake, and commenced our descent of this noble river. The scenery on the Yellow Stone differs slightly in its general character from that of the Missouri, the points being shorter, the river more rapid, and consequently more sinuous. Sometimes tall cliffs overhung the stream where the points terminated, presenting a fine appearance as their dark forms frowned overhead, while up their summits could be discovered the grosse-cornes bounding from crag to crag; ; sometimes we passed a noble wood just then in its richest green, and crowded with vegetation in all stages of progress and decomposition. Frequently did I stop my paddle to admire the magnificent landscapes presented to my view; the foregrounds of them formed by tremendous trees torn down along with large portions of the earth which had previously borne them, at those spots where the violence of the stream had undermined the banks. The trees were all different from our European ones, but bearing in their foliage the character of ash, oak, alder, and birch; besides those less knomn to us, as cocoa and rhododendrons, which were now beginning to blow, and presented a beautiful appearance. Willows were, as usual, in abundance, pushing in advance of the timber like the tirailleurs and skirmishers thrown out in the van of an advancing army; at the end of the point they commenced like osiers thickly crowded, the switches increasing in size until they become timber, and sufficiently large to contend for air and light with the other forest trees. A strong stunted growth of rosebushes was always to be seen as an under-cover; and as we passed along, we could spy at a distance deer caracolling about, and splendid elk stupidly roving through the woods with their noses poked straight out, and now seeming to bewail the loss of their fallen antlers. The work of paddling was so very light, that we continued 
on till late in the evening; the moon, although not in the full, sufficiently revealing the snags to prevent our falling foul of them. As we were thus rapidly stealing down the river, I heard voices talking, and called Boucharville's attention to it; but his hearing not being so quick as mine, he did not perceive any sound for some time, until at last he exclaimed, "Tenez, monsieur, nous devons prendre garde ;" so we allowed ourselves to be carried down for a minute or two whichever way the rater listed. We presently made them out to be the voices of Indians; but I soon quieted Boucharville's apprehensions, as I could distinguish those of women amongst them-a proof that it was no war-party; upo which we determined to pay the speakers a visit. We accordingly kept well in the centre of the stream, and were not long before we saw their fire upon the bank. We passed beyond the spot for upwards of a quarter of a mile, and fastening our boats, walked back along the beach to their encampment. Guided by the glare of the fire, we were soon close to them, and could unperceived survey the whole party, which consisted of two old men, one old woman, and six young ones of between fifteen and twenty years of age: four boys of about thirteen or fourteen completed the circle. Their horses were close into cump, and we saw at a glance that they were a part of the trading-party on their way to Fort Union, as the heavy packs of buffalo-robes which the horses had that day borne were piled around the encampment. We remained for some time conteroplating the scene: they had chosen a most picturesque position at the conjunction of a little river tributary to the Yellow Stone; three large green oaks headed the camp, at the foot of which a kind of awning of elk-skin was stretched over the old men's heads, a bright fire was burning at their feet, and both the romen and boys were sitting around or bustling about cooking. 
"Allons, Boucharville," said I, and we walked boldly in. Had a shell burst among them, they could not have been more terrified; the girls and boys ran away screaming; one of the old men seized a gun, another his bow and arrows. However, we soon re-assured them, and on a further examination, one of the old men recognised an acquaintance in Boucharville, who having once been hunter at the Crow post, was known to all the principal men of that tribe; so that in a few minutes we were seated round the fire with them. Of course I could not understand a word of the conversation; but Boucharville spoke fluently, and Indians are so wonderfully intelligent and quick at comprehending signs, that yon can, by their help, make them understand almost anything: I soon saw that they were short of meat, so I.told Boucharville to slip out quietly (taking care that none of them followed him), and bring them some from the boats. I made use of this latter precaution, fearing that some of the boys might steal our things, and was by no means inclined to trust them too far. Boucharville soon returned with the meat, which was very welcome, and we all supped together.

As soon as supper was over we returned to our boats, notwithstanding their anxiety that we should spend the night with them. Arrived, we lighted a driftwood fire, for it was very cold, made ourselves some coffee, and turned in for the night.

Next morning we rose very early and got under way: about noon, however, it came on to blow so hard that we were obliged to put in to the bank of the river. At sunset, when the wind went down, we voyaged on for two or three hours; and the following evening, after a long day's paddling, reached the mouth of the Yellow Stone. My horses had just arrived with Paquenode and Pérey. All the Crow Indians came in, including the party we had met on our descent. 
They were delighted to see us, and ornamented my elk-skin hruting-shirt on the breast, and along the sleeves, with a most brilliant porcupine-work edged with blue glass beads in return for the meat I had given them.

\section{CHAPTER $\mathrm{X}$.}

Dispose of the meat.-Descend the Missouri.-A War-party.- - They decline the attack.-Obtain two more followers.-Kill a young Bear.-The grisly Bear.-A breakfast of Marrow.-Nearly kill two Eagles with a ball.-Chase and capture two Bison Calves.Return to Minitaree Village.-Scaffoldings for the Dead.-Indian Games.-Death of Mr. Chardon.

I PAID a short visit at Fort Union, where I disposed of my meat, and received my supplies of porder, lead, coffee, and sugar ; after which we again assembled in the camp we had occupied previous to our departure from the Missouri to hunt up the Yellow Stone. Althongh I was visited in my camp by several Crow Indians, I was fortunate enough not to lose anything, which was possibly owing to the sharp look-out we kept. At last they all came and camped round me, and I found on inquiry that they intended going down to the Minitarées on a visit, for the Crows and Grosrentres have always been on friendly terms, and I believe were originally the same tribe. I thought this, therefore, a very good opportunity to send my horses back to Fort Berthold, and descend the Missouri in my skiff. Accordingly I sent off Peekay with the four horses to accompany the Crows on their land journey, while Boucharville, Paquenode, and I, proceeded to disinter the skiff which we had buried at the mouth of the Yellow Stone, and in less than two hours were lloating 
once more along the broad waters of the Missouri. We pulled and steered alternately, relieving each other of the hard work at intervals. The boat was a heavy one for three oars; but the stream was rapid, and we descended at the rate of more than five miles an hour for two days, eamping at night on the river's bank. Ishmah accompanied us; his place being in the bow of the boat, where he used to rush with the greatest delight and lie down, keeping his head out of the way of being punched by the fists and oar-handles of the rowers.

On the morning of the third day I was attracted, by some very tempting rocky-looking cliffs overhanging the left bank of the river, to try and get a shot at some grosse-cornes. We put ashore, but as there was no timber near the spot, we had all to go to some little distance before we came to a suitable place for our camp.

There we tied up the boat to the roots of a drifted tree, and having arranged a rendezvous, Paquenode set about making a camp-fire, while Boucharville and I started off sheep-hunting. We were not long before we came in sight of some, on the broken country at the back of the cliffs, and were creeping cautiously round to get to leeward of them, when Boucharville suddenly stopped, and bidding me lie down, put his hand up to shade his eyes, and stooping at the same time as low as possible, pointed out to me some objects at a distance, and but partly visible, on account of an intervening slope. It was with the greatest difficulty I could see them, and it was only after a long look that I became satisfied they were a band of elk. We continued our course for a little while, when Boucharville exclaimed with great earnestness, "Tenez, monsieur, ça que nous avons vu à cette heure, ce n'est pas la biche, j'en suis sur; je pense bien qu'ils sont les Peaux Rouges!" I quite laughed at the idea, but Boucharville was positive now. "Nous verrons," raid he, "wagh!" and so strngg]y 
did he suspect the existence of danger, that I agreed to go back with him to Paquenode. We had hardly reached the camp, and were detailing the suspicious appearances we had seen, when suddenly a large war-party of naked painted savages seemed to spring out of the earth and make towards us. Paquenode's terror was at its height in an instant, but fortunately, though shaking all over, and his teeth chattering like castanets, he was too frightened to run. Boucharville and I at once agreed that our only chance of safety was to stick to the timber, where, if things came to the worst, we could make a retiring fight of it; and in this determination we were much re-assured by our acquaintance with Indian courage and warfare, knowing that, however eager they may be in the pursuit of scalps and horses, they are always most careful to avoid any loss on their own side; whereas, from our advantageous position in the timber, any attack upon us must have cost them several lives. So each taking his post behind a tree, with a couple of bullets in his mouth, we awaited a further advance. After a good deal of seeming hesitation, the Indians appeared to have come to the unanimous decision of leaving us alone, and drew off; so, skirting the timber to the point where our boat was moored, we reached it unobserved by the enemy, and were soon running down stream. Fortunately the rascals had never seen our boat, or they would have been certain to have cut off our retreat; and so, altogether, our escape was a lucky one.

As we were on our way, Boucharville exclaimed, alluding to our companion, "N'est-ce pas une chose terrible quand un homme a peur comme ça!" but it was constitutional with him. Boucharville related to me a characteristic anecdote of him, while we were cooking our supper. "Souviens-tu, Paquenode, lorsque les Gioux sont venus en guerre contre les Grosventres lat-bas 
au Fort de Monsieur Chardon?" (i.e. the Minitarée Fort). "Ah! laisse-moi donc tranquille!" replied poor Paquenode, who felt that he was being roasted as well as the supper. I insisted, however, on knowing the whole story; whereupon Boucharville, in spite of Paquenode's numerous interruptions, informed me, that on the occasion alluded to, the Sioux had come in a war-party against the Minitarées and an excellent battle was fought, - a much better one than usually takes place between hostile Indians, - in which the Minitarées were victorious. When the period of rejoicing arrived, which invariably succeeds an Indian victory, Paquenode, whom nobody had noticed during the tumult of the engages ment, was to be seen in the midst of the revellers, the gayest of the gay and the bravest of the brave, recounting his mighty deeds of the morning in true Indian style. It was observed as rather strauge, however, that a good deal of dried mud was sticking about the collar and shoulders of his blue capote. Now the weather it seems had been wet, and it so happened that a pit had been recently dug, in which to stow some of the Minitarée corn; and into this pit footprints led: these, it was quite clear, did not in the least resemble Paquenode's; no, not at all! The interruptions to Boucharville's story here became so frequent and vehement, that the rest must be left to the reader's imagination, as it was to mine.

As we were proceeding down the river the following day, we observed two white trappers on the bank. We immediately put in to accost them, when, to our utter amazement, they both ran away, leaving their bull-skin boat, some good meat, divers excellent peltries, and a beaver-skin or two, in our hands. Boucharville, however, followed them, and succeeded in persuading one of them to come back. He told us that his name was Dauphin; that he had been in the employ of the Fur 
Company; had run into debt for traps and outfit; gambled amay everything; and when he saw us, was under the impression that my boat had been despatched in pursuit of him from some of the company's posts. He was much comforted on learning who I was, as he said he was out of powder, and had no lead; that the only meapons he and his comrade possessed were a very bad rifle, which leaked in the pan, and but seldom went off, and a pistol that stuck at half-cock; and that they were then actually employed in making bors and arrows: he added, that they would gladly come with me, if I would accept their services; and on my assenting, started off to find his companion, congratulating himself on his good luck in having fallen in with me. I therefore chose a convenient place for camping; and after an hour or so, the fugitive, Gardépée by name, was ushered into my presence. TVe now mustered a party of five, which promised to render the management of our skiff a much less laborious affair. Cheered by the comfortable prospect now before them, these youngsters recounted their adventures, and, indeed, seemed to have got on very well, until their fire-arms had become almost unscrviceable, and their ammunition nearly exhausted. On the morrow we found two good pieces of driftwood, calculated to make a couple more oars, which we were not long in completing; and then, with Ishmah in the bow, and Paquenode steering, we went along in capital style.

Next day was so windy, that we could not continue our descent; so I went out to look for black-tailed deer, in little thickets of brushrood, on the old red sandstone hills about the mouth of Knife River. I shot a fine buck, and was busy skinning it, when I heard, "Monsieur, venez ici!" loudly shouted. I looked up, and just saw the figure of Dauphin vanish over the brow of a hill. Of course, I followed with my loaded rifle, and, 
on reaching the summit, beheld a bear standing on his hind-legs, and staring about him in every direction, while Dauphin, concealed from his view by a rock, was industriously snapping his pistol at him. On seeing me, the brute shuifled off at a great pace; but when I came ap with Dauphin, the latter, imitating the croaking of a buffalo-calf, brought him back again a little way, so that I got a shot at him, and hit him in the flank, though, blown as I was by my ascent, I could hardly hold my breath to take aim. The bear clawed at the spot where the ball struck him, and charged up to within twenty paces of us, while I was reloading; whereupon Dauphin snapped his pistol again at him without effect. Fortunately for us, Bruin was only a tro-year-old, and afraid to rush in, though large enough to have smashed both of us, defenceless as we were at the moment, and, before I could get on my percussioncap, bolted over the brow of the hill. I was still so thoroughly blown from my run over the rocky ground, that I gave up my heavy rifle to Dauphin, who threw down the useless pistol, and started in chase, I following him. He soon got a shot at the bear, who turned round, clawed at the wound, gave a savage growl, and ran into one of those little clumps which always mark a watercourse in the hilly country. I took the rifle again, loaded, and pursued the enemy right into the clump, in spite of the remonstrances of Dauphin, and, getting a sight of him first, gave him a finishing shot between eye and ear. Although he was but a young bear, only in his third year, it was with great difficulty that we could drag him out; he measured five feet four inches from the rump to the muzzle, and his claws were three inches and three-quarters long. Had he been fully grown, and possessed of that amount of courage and ferocity with which the old grisly bears, both male and female, are endorred, it would certainly have fared badly with us 
that day. However, we skinned our prize with great satisfaction; and I was exceedingly pleased with the pluck and daring of my companion, who laad been twice charged by the bear, and whose pistol had twice snapped.

The grisly bear is an animal very little known in this country, the damp climate of which does not agree with him. The celebrated Catlin brought over one or two specimens; but they met with the fate that almosi invariably attends pets-an untimely end. There are now some young specimens of the grisly bear at the Zoological Gardens of the Regent's Park; but I fear they do not promise well; they are not attaining the size to which their age entitles them. The grisly bear is poetically and justly called monarch of the Pocky Mountains-a name to which his size and ferocity fully entitle him, as he roams over these vast solitudes fearless of everything. The full-grown male measures eight feet six inches from muzzle to stern, and about that size round the body; his feet are in shape something like those of a negro, and are about eighteen inches in length, armed with claws fully five inches long; his arms and legs are enormously powerful; and as be walks and trots, he moves the hind and fore fout together on the same side, and rolls his head at every step. In colour he varies a good deal, from a common brown to a beautiful steel-grey. He differs materially from the common brown bear in the size and shape of the head, which is much larger, and also in the forelegs, which are not only much stouter, but covered with very strong wiry black hair, while his claws are much longer and stronger than those of the bromn bear. Naturalists are divided in their opinion as to whether the grisly bear climbs trees or not; but I am perfectly convinced that he does not. Men have told me of escapes they have had from them by ascending trees; 
and one trapper, named Joe Uno, told me that he once had a mocassin torn off his foot, while in the act of escaping up a tree, by the stroke of the ponderous paw of a grisly bear, which, however, was unable to follow him, and sat for a considerable time at the foot of the tree, watching for him to come down.

The evening was very wet and windy, and next morning I arroke with a terrible toothache. I felt as if all my teeth were too long; and eating my breakfast was attended with such pain, that I was compelled to relinquish the task (though I had a fine appetite), and to solace myself with a pipe, while my companions were discussing tough buffalo and venison. As I lay in view of the river, I saw some dozen buffalo-bulls descend the opposite bank, plunge into the stream, and commence crossing the river. I ran down to the spot where I knew they would land, having observed it the day before, and reached it just in time to conceal myself as the foremost bull ascended the bank. He passed close to me, receiving, as he did so, a mortal wound; he pawed the ground, looked about him, saw nothing upon which to vent his rage, lay down, and died. I knew that, being the foremost bull, he was most likely the one in the best order; so I drew my knife, and soon possessed myself of the four marrow-bones; then stripping off some of his strong hide, I made a cord of it, and loading myself with them, returned to camp provided with a breakfast more suitable to the state of my teeth. I roasted the bones, and made a inost delicious meal of the rich soft marrow. It was so good, that Boucharville and Dauphin, to whom I lent my rifle, went after the rest, and in a couple of hours returned laden with marrow-bones. I remained the rest of the day in hopes of finding a bear, but was disappointed. In the evening: I went down, accompanied by Dauphin, to the spot where I had shot the bull, in hopes of finding 
¿ wolf there; but as we drew near it, a wary prowler, that had been feasting himself, perceived our approach, and sloped off before I could get within shot of him. I observed a strange fluttering, however, at the carcass, and, looking carefully to discover the cause, sar, to my surprise, two eagles fighting like Bantam cocks for the possession of the carcass. At last, one of them flew up and perched on a branch of the tree overshadowing the fallen bull; the other immediately pursued and renewed the fight, striking fiercely with beak and claws at his adversary, who appeared to me to be parrying with his wing's the strokes of his assailant's talons. I raised my rifle, while about sixty yards from the combatants; but unfortunately, as I drew the trigger, the attacking eagle soared up a little, and thus escaped the bullet, which, passing right through the breast of the other, brought him to the ground. Had I fired the fractional part of a second sooner, I should have performed the curious feat of killing two eagles at one shot with single ball!

The morrow was a long, hard day for my men. They had to make the whole of the Grand Détour, a distance of upwards of forty miles, while I took by myself a short cut across the prairie, agreeing to put up some obvious mark on the bank of the river where I should stop, and to provide supper for the party, as our meat was nearly finished. We accordingly parted company; the men in the boat taking their circuitous route by the river, and I my straight line across the prairie for the opposite extremity of the bend, a distance of about fifteen miles; Ishmah, sorely against his will, remaining in the boat. I reached the end of my journey long before the others, chose a point for a convenient camping-place, and went out to hunt. I was fortunate enough to kill a fine four-year-old buck as he was on his way to drink at the river, and by shooting him in 
his tracks, found I had no distance to drag him, as the spot where he fell was not thirty yards from the river, and in a straight path for bringing water up and down in the kettles. I thereforc skinned him at once, and fastening his hide to a stick projecting horizontally from a tree overhanging the river, as a beacon to $\mathrm{my}$ companions, I lit my fire, cut up the game, and sat patiently awaiting their arrival. I'hey came before sunset, and had no difficulty in observing the deer's skin. As the sun sank in clouds of purple and gold, betokening a windy morrow, we lashed our boat well up, took plenty of things ashore; in short, unloaded almost all the cargo, and made ourselves comfortable for the night. Morning dawned, accompanied with a wind that effectually prevented any progress that day; so Dauphin, Boucharville, and I took a ramble to survey the prairie beyond the timber where we were encamped, leaving Paquenode and Gardépée to take care of the camp and boats. As we emerged from the point, we came in sight of a large herd of buffalo-cows lying chewing the cud on a fine grassy spot. Many of them we perceived to be heavy in calf, while some were fat and barren; and I may here take this opportunity of mentioning a conclusion at which I have arrived from careful observation of these animals, which is, that they only breed every second year; for the cow remains with the bull as early as the end of June, or beginning of July, and does not calve until the end of May or commencement of June following, from which I infer that she carries her calf for at least ten or eleven months, two months longer than the period of gestation with our own cattle. On seeing the cows lying in that position, Dauphin and I crept round behind a rising ground, and arranged that Boucharville should endeavour to get within shot of one of the barren cows; but before we separated, Dauphin, whose quick eye 
ras always on the alert, suddenly" exclaimed, "Tenez, Boncharville, royez!" and, pointing to one of the lean, distended cows, continued, "cette vache va faire son veau à cette heure ; attendez un peu arant d'approcher!" and hardly were the words out of his mouth, when she leaped up and calved with one very slight effort. "Allons, l'attrapper!" exclaimed I, and leaving Boucharville staring after us in utter astonishment, we started in pursuit of the little fellow. The cow, of course, went off, and at a tolerable pace, followed by the calf, at an astonishing rate for so young a beast. Dauphin wanted to shoot the mother, in order not only to shorten the race, but to increase our chance of rearing the calf, by cutting off the cow's udder when dead; but that, of course, I would not allow, and ended the discussion by knocking up the muzzle of the rifle which he was using with the barrel of my gun. Then bidding him follow my example, I threw down my gun to lighten myself, calling on Boucharville to take care of the two; and draming our belts a hole tighter, we dashed off again up hill and down dale, till at last we stretched away right out along the prairie for five or six miles. By-and-by the little calf began to show symptoms of failing, and the cow, allowing her instinct of self-preservation to overcome her materual attachment, made the best of her way off, and crossing some inequalities in the ground, was lost to the sight of her offspring. The little fellow then stopped; whereupon Dauphin, who possessed a wonderful facility for imitating the calls of animals, immediately began to grunt like a buffalo-cow, and to our great amusement the little beast turned about, cocked up his tail, and came galloping back to us. We then turned about, and to our great delight it frisked round us all the way into the camp. I was mast anxious to get it to the fort as early as possible, for I knew that if I could do so in time, I might by 
chance be able to rear it on pounded Indian corn and lukewarm water.

Very early next morning we repacked our boats, got in our little calf, whom we dosed with strong broth for want of more congenial nourishment, and took our course down the river again, in hopes of reaching the fort that night. We pulled very hard, not stopping to eat at 12 o'clock; but about that hour, and while in the act of rounding a point, we came across a whole band of buffalo in the act of crossing the river. We could pull faster than they could swim, so, cutting our sk: $n$-boats adrift, with a triumphant yell, we steered the skiff right among the snorting throng, and singling out a brave little calf that was swimming like a water-rat, we gave chase. Young as he was-and he could not have been more than a day or two old-he gave us a great deal of trouble, turning and dodging with wonderful quickness. At length, in endeavouring to swim against stream, the little wretch was drifted back alongside the boat and captured; so that we had now a pair of these interesting: animals on board. We pulled on in great spirits till some time after sunset, but were unable, with all our exertions, to reach the fort that night; so we camped and cooked, drenched our little calves with strong broth, drank the last of our coffee, and after talking over our adventures, turned in for the night. I thanked my men very heartily, and gave them all praise for the immense exertions they had used to aid me in obtaining the calves and bringing them safely to the fort, as I had the greatest anxiety to convey the bison to Europe-an object which I am happy to say I subsequently succeeded in effecting.

Next morning we got under way at daybreak. When near the fort, I saw a splendid male antelope, with the largest head of hoins I ever saw. I unshipped my oar, drew up my rifle, and missed him, on which he very 
quietly walked on a pace or two. Boucharville then handed me his rifle; I fired, but unfortunately the bullet striking just above the animal's eye, so shattered the skull as to make it unfit for my collection. We pulled into the fort in time for breakfast, welcomed by poor Mr. Chardon, who was the bourgeois, or head manager, of Fort Berthold. He had then been for a long time ill with rheumatism, and on my return to the fort I found him worse. He seemed quite to long for any one to talk to him and enliven the weary hours that he passed on his sofa hardly able to stir; so I occupied myself in making some shot, while I recounted my adventures to him, or laid plans for future expeditions. In the evening I generally joined the Indians, and sat with the old men watching the women playing at ball, or the young men at their different games. My horses had arrived quite safely with Pérey and the party of Crow Indians; so that on the whole my hunting expedition had turned out most prosperously. The weather had now become warm, and the place was decidedly unhealthy, owing to the vile habit these Indians have of not burying their dead. Instead of doing so, they place them aloft on a framerrork of sticks; so that, around the camp, you see these scaffoldings in all directions, bearing bodies in every stage of decomposition, and merely wrapped each in $4 \mathrm{n}$ old buffalo-robe. Near each is also hung his medicine, $i$. e. any little thing that during his lifetime he may have deemed a preservative against danger, or a charm against sickness, or miraculous agent assisting him to find buffalo, \&c.: his pipe likewise, if he had one, is also laid beside him, and a bow and arrows, which it is supposed he will hereafter need when admitted to the hunting-grounds of the blessed. A strange anomaly seems, however, to prevail, and one inconsistent with this great apparent respect for the dead; namely, that 
an Indian will not hesitate to appropriate any part of the dead man's paraphernalia, provided he replaces it by an article of the same kind, no matter how inferior or how much previously injured; for instance, if an Indian has an arrow without feathers or headless, he does not scruple to exchange it for the best arrow in the deceased's quiver. When the skulls fell off, they used to placc them in circles, together with, I believe, some of enemies which they may have taken as trophies-at least, those of such as were slain near their village. 'l'heir houses, unlike those of the Assineboines, are built of rood curt in piles and plastered with mud, and in outward shape resemble apple-dumplings; so that, when the boys race about the village, they run over the tops of them with the utmost ease. I was much amused one evening at witnessing a game of this nature. One young fellow, of about eighteen, was shaded along the ribs with white chalk in such a way as with his red skin to look ludicrously like an antelope. On his head they bound the horns of an old forcifer male antelope dexterously attached to a piece of the skin, the ends of which he tied under his chin, forming altogether a most entertaining caricature of the animal. He then stood on the top of one of the houses in the centre of the village, and on a concerted signal the pursuit commenced, THE ANTELOPE being chased by half a score of other youngsters, till he was at last outdodged by numbers and captured. Besides these, we had horse-races, the Indians betting sometimes very coolly, at other times with great excitement, and always paying their bets of skins, blankets, sugar, tobacco, \&c., with most praiseworthy honesty.

A day or two afterwards poor Mr. Chardon requested me to write his will for him, which I did. He dictated everything correctly and sensibly, and the day after signing it, died surrounded by us all, detailing to us 
with his last breath how some years before he had gone ont after a buffalo with another man, and while passing through some willows behind his companion, his gun had gone off, shooting the latter dead at his feet. Unfortunately, they were known to have quarrelled, and were never on very good terms with one another, so that some had unjustly accused him of having designedly shot the unfortunate man; but poor Mr. Chardon's last words were, "As I am going before my God, it was an accident." Poor fellow! I felt very much cast down at his death, and as I had ever since my arrival at the fort suffered from dysentery, occasioned by the smell of all the dead bodies about the village, I went to Boucharville's lodge, and sounded him as to his feelings upon the subject of a second hunt. "Monsieur," he replied, "où vous allez, moi, je suive! je partirai ce soir si vous voulez." So we finally arranged to set off next day, convey the horses across with my skiff, hunt up the Little Missouri, and try the T'urtle Mountains, famous for grisly bear.

\section{CHAPTER XI.}

Another Hunting Expedition.-The Turtle Mountains.-Dangerous Hunting Country.-My last Buffalo Hunt. - Sold by an Antelope. - Attacked by and kill a grisly Bear.-Her cubs hows fight.Depart from the Turtle Mountains.-Attack a grisly Bear.More grisly Bears.-Mr. Denig's Adventure.-Bear smashing a Buffalo.-Murray and his Mackinaw Boats.-The Pipe of Peace. -Shake hands with an old enemy.-An Indian Battle.-Cannibalism.-Arrival of the Martha.-Death of poor Sinith.

As on the former occasion, I laid in good store of powder, lead, copper caps, awls, and coffee, to which I added a large quart bottle of molasses as a substitute for sugar, that article being rather scarce at the fort. With sad- 
dles, bridles, \&cc., I was well provided, so that my arrangements were quickly made; my horses crossed well, and I did not experience anything like the diffi. culties attending my start from the Yellow Stone. got well away on the opposite prairie ; and, once out of sight and smell of the fort, my spirits rose, my appetite returned, and the dysentery departed. We camped late in the evening beside a refreshing stream, which flowed through a beautiful copse, and spread our beds among the now fragrant rose-bushes.' What a change from the noxious atmosphere of the fort! We sat long talking of poor Mr. Chardon as we smoked our pipes and sipped our coffee after supper, till one by one fatigue overcame as, and we slept soundly till dawn. Much refreshed, we arosc, stirred the embers of our fire, ate our breakfast, brought in the horses, and were soon in the saddle and en route. That day we shot a fat buffalo-cow, and carried with us the hide and marrow-bones; and two nights afterwards camped within an hour or two's ride of the Turtle Mountains, which we reached early on the fourth day of our journey from Fort Berthold. Approaching Turtle Range from the eastward, you pass over a level grassy prairie, out of which, like an island from the sea, rises "La Montagne de Tortue" par excellence. A light band of vapour veiled the splendid landscape from our eyes, revealing above and below its gauzed drapery the hill-sides belted with wood, and intersected with little threads of rivers, marked by rugged lines of timber and scrub fruit-trees, the favourite resort of grisly bears in the autumn; at which season they congregate, as I was told by Boucharville, in such numbers as to prevent any one from hunting through them except on horseback, and at great risk even then. To this fact, however, I am unable to bear testimony, as I arrived there only in the month of June, far to soon for fruit. 
As we ascended, the day grew very warm"; the sun chased away the mist, and ridges and declivities in the mountains, hitherto unperceived, showed themselves before us. We continued to ride up and down through cedars, green oak, rhododendrons, and all kinds of wild fruit-trees, till we reached a little river at a spot where a party of Minitarées had camped the year before. They had built a triangular lodge of long wooden poles, like hop-poles, piling them in the shape of a cone, and so closely as to render the hut bullet-proof-a necessary precaution, as they could never venture there save in fear of their lives, the position lying in the regular pass of the Sioux when they go to war either with them or the Crows. We took possession of the hut, not sorry to teel ourselves in a bullet-proof shelter, in a place where, I must admit, we ran some risk of being surprised by an Indian war-party; but I was so anxious to hunt the grisly bear, that I could not endure the idea of leaving the country without a closer acquaintance with the monarch of these mountains. As a general rule, the more dangerous the country the greater the probability of finding abundance of game, showing in more ways than one the truth of the old sportsman's adage, "the more danger the more sport." This part of the country is so evidently the line of direction between the three hostile tribes, that none of them dare venture into it for hunting purposes, except when driven to desperation by hunger, they endearour to snatch their game from between the jaws of Seylla and Charybdis. Nuch, therefore, as I enjoyed the locality for a hunting-camp, seeing buffalo on all sides, elk feeding in the distance, and fresh deer-tracks in every direction, leading to and from the inviting streams that ran down the slopes, Boucharville did not relish it at all, and began already to calculate how soon we were to go away. My hunting days I knew to be drawing to a close; the steamer of 
the American Fur Company would be due very soon, and I had not much time to spare. After breakfast I saddled $O$ wen's horse, and descended the hill for a run at buffalo. I chose a band of cows, most of whom had calved, and whose little ones scampered at their heels: passing these easily, I detected one or two fat barren ones in the van, and gave chase. Some bulls who had caught sight of the running cows now began to run also, and bulls and cors intermingled were soon pelting along in a confused mass. I did not care to fire at the former, and was pressing on after a fat cow I had selected, when one of the bulls, a little blown by the race, stood still for a moment, and as I doubled across him after my cow, made a headlong rush at me; I could not pull in, and to turn was destruction; I had nothing for it but to lift my horse, and giving him a tremendous cut with the whip, he sprang into the air, and just cleared the bull when in the act of charging. I felt my horse's hind-legs carried aside as they caught the brute's shoulder, or head, or neck, I can't say which; but we dashed on happily unhurt, and the next instant I was passing the cow, when, standing up in the stirrups, I gave her a shot that brought her rolling on the plain. I now carefully examined 0 wen's horse, and thanked my stars that we had escaped unscathed, resolving in my own mind that it should be the very last time I would ever run buffalo mounted on a friend's horse. Mackenzie's horse was a magnificent animal, and nearly thorough-bred, and although the gentlest creature in the world, possessed the most indomitable spirit, as a subsequent adventure will show. I brought away the hide, fleeces, the eight marrow-bones, and my favourite piece, the brochet, so that we fared sumptuously that day. Next morning I went out to hunt with Boucharville. Pursuing a westerly direction on leaving the camp, we made for a more rocky part of the range 


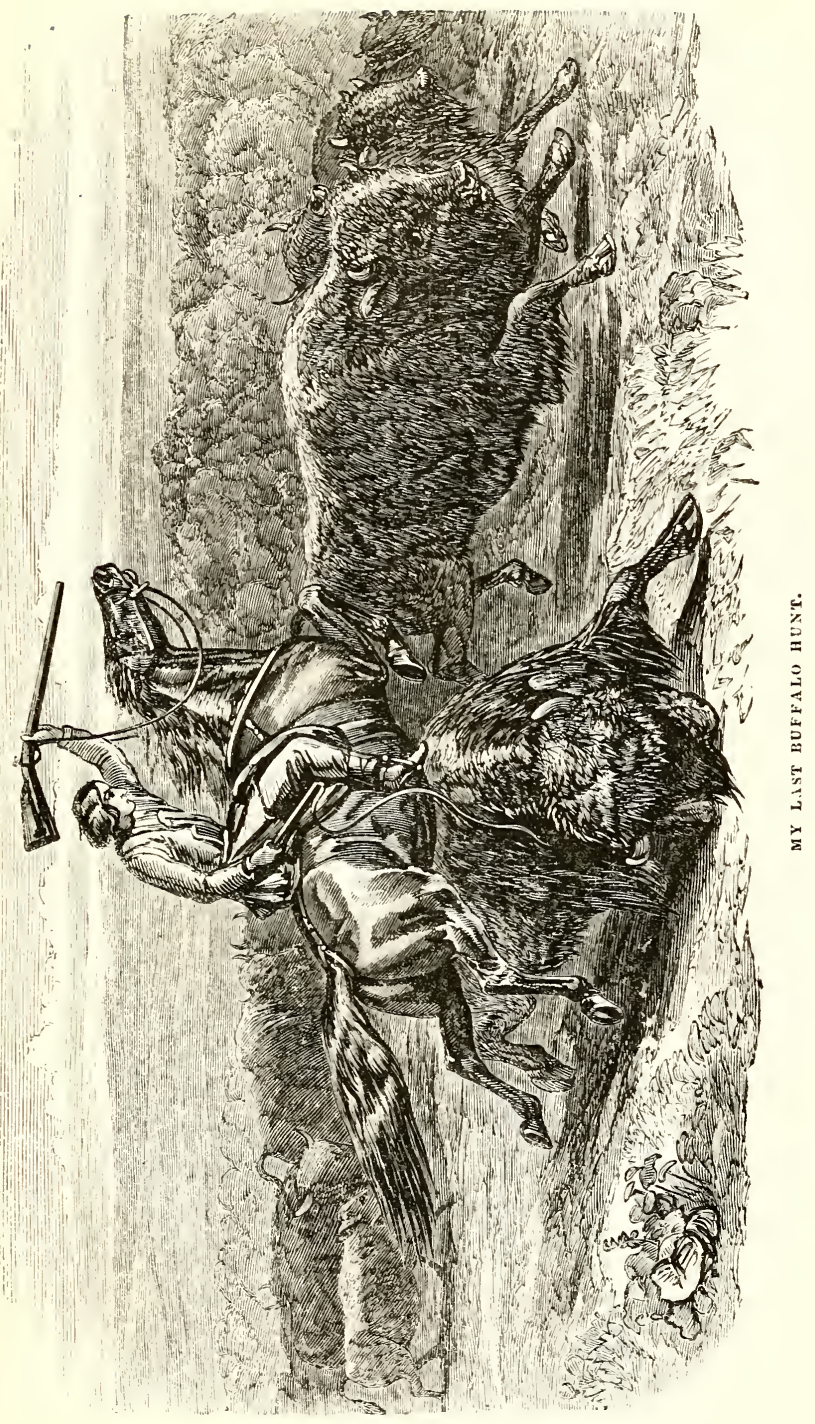



where the fromning overhanging cliffs gave a promise of big-horn on our way. As we went, I got a long shot at an antelope (for which I dismounted expressly), and the animal instantly dropped; whereupon I remounted, and, not stopping to load, rode up to the spot, and found him a fine old male with large full-grown horns. Boucharville now came up congratulating me upon my having got such a fine specimen for my collection, and as I sat quietly upon my horse discussing the length of the shot, he dismounted, and drew his knife for the purpose of skinning the apparently lifeless animal, but before doing so, began to sharpen it upon his steel, which hung at the belt of his hunting-frock, when, to our amazement, the antelope, after one or two convulsive struggles, jumped up and bounded off safe and sound, turning about when a couple of hundred yards off, to look back at us as if in ridicule, and again darting. awray, bade us a final adieu. As soon as we recovered from our surprise, we both burst out laughing. I dismounted and loaded, and we went on to the cliffs close by. We rode for some distance along the base, but seeing no sheep, crossed the ridge, leading the horses after us up the ascent, and over rocks and places over which the poor animals could hardly scramble, accomplishing this with great difficulty. We had hardly commenced our descent on the other side, when Boucharville's quick eye perceived under the cliffs, about 300 feet belor, a doe elk feeding in a glade surrounded with thickets of fruit-trees and rose-bushes. With his usual deliberation, he drew out and stuck crosswise in the ground his ramrod and loading-stick for a rest, and a deliberate shot brought the elk down on her tracks. The spot from which he had fired was so steep, that we were obliged to turn back and take a more circuitous course to reach her. Boucharville, who had not loaded, went at that moment to a stream about thirty paces 
from where the wapiti lay, saying, "Je vais laver ma carabine ;" and I, leaving my horse to graze, having taken off his bridle and unrolled his halter, was busy, knife in hand, removing the elk's skin, when Boucharville, who by this time had his rifle-barrel in the stream, and was sponging away very diligently, suddenly shouted, "Un ours! un ours!" and at the same instant a she grisly bear emerged from a cherry-thicket, charging right at him. Boucharville, dropping his rifle-barrel, sprang back into a clump of rose-bushes, when the bear, losing sight of him, stood on her hind-legs, and I then saw she had a cub of a good size with her. I at first ran to assist my companion; but seeing him safe and the bear at fault, I rushed back to the horse to secure him, fearing that, were he to smell the bear, he would soon speed his way over the prairie, and be lost to me for ever. Seeing me run, the bear instantly charged after me; and when, having reached the horse, and rolled the halter a couple of times round my arm, I turned about to face her, she rose on her hind-legs. I did not like, however, to venture so long a shot, as I had only a single-barrelled rifle in my hand, and paused. a moment; when she altered her intention, turned aside, and followed the direction taken by her cub. I then canght a glimpse of her as she ran to the left, and fired through the bushes, but only hit her far back in the flank; on which she immediately checked her onward course ; and wheeling round and round, snapped at her side, tearing at the wound with her teeth and claws, and, fortunately for me, afforded me sufficient time to enable me to load again; my ball was hardly down, when a shout from Boucharville warned me that the fight was only commencing. "Gardez-vous, gardezvous, monsieur; elle fonce encore," and on she furiously rushed at me. I had barely time to put on my copper cap, and as she rose on her hind-legs, I fired, 


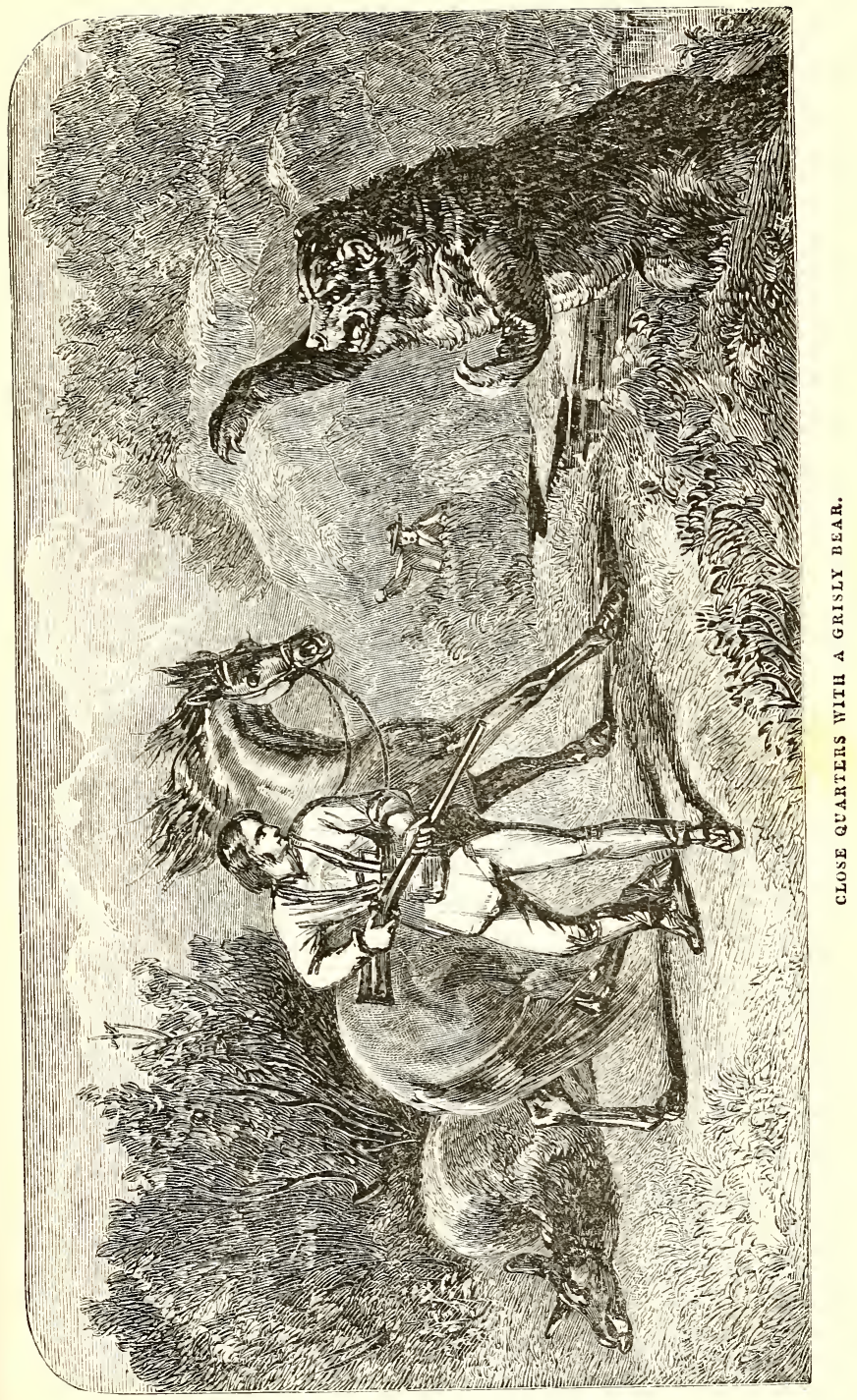



and sent my bullet through her heart. She doubled up, and rolled from the top to the bottom of the slope, where she expired with a choking growl. Boucharville now joined me, but we did not venture to approach the enemy until I had loaded, and we ascertained that she was safe dead, by pelting sticks and stumps at the carcass. All this time my noble horse stood as firm as a rock; had he reared or shied, I should have been in a serious scrape.

I was greatly rejoiced at my good fortune. She proved a fine old bear, measuring seven and a half feet in length, with claws four and a half inches long. We immediately set to and skinned her, preserving the claws. I then brought up the horse, and laid the skin upon his back; he, strange to say, offering no resistance, nor evincing the slightest fear or objection to carry it-a most unusual thing, for horses in general are terrified at the smell of a bear; and I never saw one since that would allow me to throw a bearskin across his back.

Dauphin, on our reaching camp, and relating our adventure, took a couple of coils of rope and his rifle, and started off to try and catch one of the young bears. I thought the prospect of his finding them so doubtful, that I did not accompany him, and was afterwards very sorry I did not; for, after being some hours away, he returned, having shot one little bear, and attacked the other with $a$, view of capturing him alive. The little b : te, however, fought so fiercely as to tear his clothes, a cut him with his sharp claws. Dauphin had fortunit ly provided himself with a good thick stick; but, no rithstanding this advantage, he was right glad to $r$ quish the fight, and leave it a drawn battle. At - time, he told me, his adversary had secured his leg; a) very nearly succeeded in dragging it to his mouth; in which event he would have hurt him severely, when 
a couple of hard blows on the nose made him let go his hold, but only to renew his charge again and again, notwithstanding repeated thwacks on the head from the young hunter's stick. "Et, monsieur," continued Dauphin, " enfin il est échappé, le s'cré petit enfant du diable !" The skin he had brought home was a beautiful one, as indeed are the skins of all young grisly bears, whose fur is thick, of a tawny colour, with a stripe of a darker hue along the back, and so long and shaggy, that it shakes up and down as the animal shuffles along. In the evening I took a ride with Dauphin, more to enjoy the exquisite landscape than for the purpose of hunting. Our course lay through cedars and rhododendrons, and we found regular paths in all directions made by elk and buffalo, who travel through every wood. In the whole of this region here is not a thicket or point that is not rendered easy to traverse from this cause ; and it will be easily imagined that a succession of these heavy animals following in each other's wake would soon form a very convenient ridingtrack. We returned about sunset with the skins of two wapiti, now valuable as being in the red. As we sat round our camp-fire at night, Boucharville remonstrated much on the danger we ran by remaining in this delightful spot, and pressed me so hard, that before going to rest I reluctantly consented that we should depart the following day, taking a northerly direction until we should fall in with the Little Missouri, which we would follow up and down to hunt for bear and bighorn. Accordingly we started on the morrow, Dauphin travelling on foot, as his horse was heavily laden with the trophies of our hunt in the Montagne de Tortue, and before noon we arrived at some very rocky, shingly hills, over and along which we rode with much difficulty, having frequently to dismount and lead our horses. Dauphin here descried a grisly bear lying down 
and sunning himself on a ledge of rock high up the side of a hill, and, contrary to my directions, instead of waiting for us, ran on while Boucharville and I were loosening the halters of our horses so as to catch them again more easily, and, under cover of the rocks, got within forty yards of the hear unperceived. He took deliberate aim, but missed him; the bear instantly made off for a thicket of brushwood, while I, not a little annoyed, ran along the base of the cliffs to cut off his retreat; but all to no purpose ; the brute passed me at some distance, giving me a snap-shot at him which did not take effect, reached the timber, and the ground being too hard for us to track him, finally got away unscathed. As may be supposed, I was in no enviable humour ; Dauphin kept out of my way, and I rode silently and sulkily forward. At last my philosophy prescribed a whiff of the pipe, which I drew out, struck a light, and my wrath soon vanished in smoke.

On reaching the Little Missouri, the weather looked gloomy and threatened rain, so Boucharville engaged to build a very comfortable "cabane." 'This experienced rover of mountains, woods, and prairies, was up to a thousand little expedients to obviate difficulties and alleviate inconveniences, and was doubly anxious to render me comfortable, now that I had acceded to his wishes, and abandoned my hunting elysium, the "Montagne de Tortue." Leaving Dauphin to assist him and look after the horses, I went up the river with my double-barrelled gun to look for ducks; but they were very wild, and I bagged none. At length I came to the putrid carcass of a bull, and on the mud all around saw the tracks of a large old bear, some of which led from the carrion along a dry watercourse, and looked very fresh. I drew my shot charges, rammed down a couple of bullets, and followed the tracks over an undulating prairie, till at a distance I descried a very large 
bear walking leisurely along. I approached as near as I could without his perceiving me, and, lying down, tried Dauphin's plan of imitating the lowing of a buffalo-calf. On hearing the sounds, he rose up, displaying such gigantic proportions as almost made my heart fail me; I croaked again, when, perceiving me, he came cantering slowly up. I felt that I was in for it, and that escape was impossible, even had I declined the combat; so cocking both barrels of my Trulock, I remained kneeling until he approached very near, when I suddenly stood up, upon which the bear, with an indolent roaring grunt, raised himself once more upon his hind-legs, and just at the moment when he was balancing himself previously to springing on me, I fired, aiming close under his chin : the ball passing through his throat, broke the vertebræ of the neck, and down he tumbled, floundering like a great fish out of water, till at length he reluctantly expired. I drew a long breath as I uncocked my left barrel, feeling right glad at the successful issue of the combat. I walked round and round my huge prize, surveying his proportions with great delight; but as it came on to rain, I was obliged to lose no time in skinning him. I got soaked through before I succeeded in removing his tremendous hide, and then found it too heavy for me to take away; so I was obliged to return to camp without the trophy of my conquest. It was dark when I arrived. Boucharville and Dauphin had built a most comfortable little hut of logs and bark, and having laid down the skins and spread our beds inside, with the saddles at our heads for pillows, and a good roaring fire outside at our feet, we fell heartily to our supper of elkmeat and coffee.

At daybreak next morning I repaired on horseback to the scene of my conflict with the bear, and found, to my great delight, on my arrival at the spot, that neither the skin nor the carcass of the bear had been touched 
by the wolves. This fact confirmed to me the testimony of the hunters and trappers of these parts, as to the great awe in which the grisly bear is held by the wolves and lesser animals of prey. If a bear kills an animal, or finds a dead carcass on the prairie, he appropriates it; and though many a hungry prowler passing by may look wistfully at the choice morsel, it is like the eastern monarch's share, "taboo;" and even when the mountain monarch is absent, the print of his paw is a seal sufficient for its security. It cost me considerable exertion to place the reeking hide on my saddle; but I succeeded at last, and climbing on the top of it, lighted my pipe and rode back into camp. Riding along, towards noon we descried another bear, a lean, hungry-looking monster, prowling about searching for pommes blanches, and, to judge from his appearance, likely to afford us a pretty severe fight. In approaching him, we did not take any precaution to avoid giving him our wind, concluding, from my former experience, that he would not decline the combat; but in this instance I was mistaken, for rushing away down a ravine, he was soon lost to our view. This result, although it disappointed me at the time, yet gave me a further insight into the disposition and habits of the animal, and agreed with the accounts I had heard from many hunters and trappers with whom I had previously conversed on the subject; namely, that a grisly bear will, in most instances, run away from a man on getting his wind, unless previously wounded, or under such circumstances as to make him think that he cannot escape. Old Mr. Kipp, of Fort Union, told me that once, when on one of his numerous journeys from the States, he was in the Indian country, and had gone out of camp with his double-barrelled gun to look for ducks; he was seen from a distance by a grisly bear, who came cantering towards him. The day was fine, and the old gentleman did not know which way the 
wind blew, but had sufficient presence of mind to pluck off some of the woolly material of which his blue blanket capote was composed, and throw it into the air; and marking the direction of the current, ran a little distance round, till he got full in the line of it, and then stood bolt upright facing Bruin, who rose on his hind-legs for a moment surveying the tough old man, and then shuffled off, shaking his head as if he considered him meat rather too savoury for his palate.

The whole of that portion of territory betreen the Turtle Mountains and the Little Missouri is an excellent country for bear; indeed, in the fruit season there are sometimes too many to be consistent witl safety for the hunters. The pursuit of these animals is always more or less attended with danger, as the frightful story of George Glass and La Jennesse, who, with many other hunters and trappers, have fallen victims to the ferocity of the grisly bear, abundantly testifies. Indians will not attack them unless in considerable numbers. When an Indian descries a bear, he immediately goes and proclaims it in the camp, whereupon all hands sally out to attack their formidable enemy; and I do not think that an Indian would allow one to fire at a grisly bear if he could possibly prevent it ; in confirmation of which, I may here mention an anecdote of my friend Mr. Denig. He was out hunting on foot with an Indian one fine sunny day towards the end of spring, when, as they passed some rocky ground, his companion directed his attention to an object about fifty or sixty yards below them, which was nothing less than the head and fore-paws of a very large grisly bear which had crept to the front of his wintering hole, and was basking in the sun. "Hah," said the Indian, "now I will go and raise the camp." Mr. Denig, wha was a first-rate rifle-shot, scouted the idea, telling the Indian that he would plant his rifle-bullet right in the 
centre of the bear's forehead (which I have not the least doubt he would have done, and so have killed the animal on the spot), but to his astonishment the Indian cocked his gun in a threatening attitude. My friend thus finding himself between two enemies, one in front and the other in the rear, did not much relish his position, and moved away from the spot, beckoning to the Indian to follow him ; and when away from their common danger, called him to account for his conduct. I forget what excuse the man gave; but it was not at all satisfactory to Denig, who made the fellow walk home before him with the pan of his gun open, prudently adopting that course in preference to a harsher mode of proceeding. The sequel of the adventure was, that the man informed the camp of the position of the bear ; they all turned out, fired a number of shots, and the bear got away.

We now altered our line of march, and took the direction in which the last bear had gone, and after a couple of hours or so, observed either him or another of his species a short distance ahead. We approached more carefully this. time and on foot, and when within easy range, Dauphin called him up with his admirable imitation of a buffalo-calf, and we poured the contents of two rifles and a double-barrelled gun into his breast and head, and rolled him lifeless on the prairie. This was not the one we had seen in the morning, being in much better condition. We brought home his skin for a trophy, and the paws for supper, camping again that night on the Little Missouri. We had now such confidence in one another that we considered no bear could escape us; but our skins had so greatly accumulated that we determined to reach the mouth of the river as soon as possible; this we did in two days, and once more found ourselves, by Boucharville's excellent guidance, on the banks of the Great Missouri.

In camp that night, after supper, and enjoying a cup. 
of coffee and a pipe, the conversation naturally enough turned upon grisly bears. Boucharville told us, that when encamped one night by the side of a stream in the Blackfoot country, where he was trapping beaver, three bears, attracted by the smell of their meat which was cooking, came charging into camp, driving him and his companions out in such haste, that they could take nothing with them, and there retained forcible possession until they had consumed every particle of meat, and turned over the saddles and every item of their equipment in their greedy curiosity. On another occasion he ras going round to examine his traps, and was watching a band of buffalo as they emerged from the river and slowly ascended the bank, when he saw a bear (previously concealed in a deep rut) spring up and dash the foremost bull to the ground, ploughing his sides with his monstrous claws and rending his heart and vitals by a succession of tremendous blows. Although, in general, the bear easily vanquishes his less formidable opponent the buffalo, I heard a very well authenticated instance related by old Provost at the Minitarée, in which both parties suffered so severely as mutually to resign the conflict, move off a little way in opposite directions, and lie down and die.

Next day, on stretching and counting my skins, I determined to make another bull-skin boat to convey them down the river to Fort Berthold, and despatched Boucharville and Dauphin to kill a couple of bulls for that purpose. We divided our time between hunting and boat-building, and while at breakfast next morning were astonished by the unusual sight on these silent lonely waters, of two large Mackinaw boats belonging to the Fur Company. I hailed them, and found that they had come from the Crow post on the Yellow Stone. Mr. Murray, of Fort Alexander, my old travelling companion of the year before in our ride from Independ- 
ence, was in charge of them; he put ashore on recognising me, and we discussed past times over a cup of coffee and a pipe, after which he continued his voyage. A Mackinaw boat is the conveyance for most of the skins and furs traded from the Indians, in exchange for those articles brought up by the company's steamer. They are, as well as I remember (for I did not examine them accurately), about trenty feet long and flat-bottomed, principally filled with buffalo-robes, with a very small vacant space left in the middle for the accommodation of any bourgeois or person in charge. The whole is covered over with lodge-skin, except where the benches for the rowers are situated, fore and aft. I believe the oar's are always double-banked, and the steersman, or patron, is commander of the boat's crew; he is generally the strongest man of the party, of which he constitutes himself officer, volunteering to fight any one who offers to supersede him.

At the mouth of the Little Missouri I shot my fifth and last grisly bear. The time was now rapidly approaching for the arrival of the annual steamer at the Minitarée post; so one fine morning early in July, I packed my kettles, skins, arms, \&c., into my skin boat, and Boucharville and I, each with a paddle in hand, stepped in and Hoated down the river to the fort, leaving the horses to go by land. All reached our destination in the evening. We recrossed the hor'ses with our Fort Union skiff that had already done me such signal service, and, welcomed by my friend, Mr. Dawson, I quietly ensconced myself in the fort to arrait the arrival of the American Fur Company's steamer. I found all the inmates preparing for a great Indian ceremony which was about to take place, in consequence of the Sioux having sent a message to the Minitarées, that it was their desire to form a deputation of warriors who should come up and smoke a pipe of peace. The notice having 
reached the fort some days previously, the party at length arrived. All sat arrayed in their greatest finery of robes, Indian porcupine-adorned shirts, head-dresses of eagles' feathers, ornamented leggings and mocassins, and with a.great array of medicine-pipes. Several long speeches were made on both sides, after which a large caldron of coffee was produced and placed in the centre of the circle. It was interesting to see these fellows, hitherto always at war with each other, practising, on this occasion, ceremonies meant to produce an impression of the utmost mutual amity, though indicating to an observant spectator little more than a hollow truce; a haughty look, or a reserved gesture, every now and then conveying the offensive sense of an implied superiority. I was not a little surprised at being recognised by one of these hostile chiefs, who held out his hand in a most cordial manner to me, and on my asking him, with the interpreter's assistance, where he had seen me, informed me that he was the leader of the war-party which had nearly surprised us when we left the skiff on the Missouri to hunt big-horn, and from which I protected myself and my followers by a timely retreat into the timber. I asked him why he did not attack us; to which he replied, "We could have killed you all; but you would have killed several of us while running from us behind the trees; for white men shoot far." I sat and smoked with him for a while, and afterwards made him a present of some tobacco, so that we parted excellent friends.

Early one morning after this, when breakfasting at the fort, one of my followers, the valiant Paquenode, with whom my readers are already acquainted, ran in screaming and shouting like a maniac, rushed across the room, and would have succeeded in carrying off my double-barrelled Trulock, had I not darted to the rescue. As soon as I had succeeded in inducing the man to 
speak coherently, I learnt that a war-party of Sioux from the Teton River had been seen and reported to the village: they were then some miles distant. Not wishing to have anything to do with Indian battles, I prudently excused myself from the honour of joining the Minitarées, and going out with them to fight the Teton Sioux, preferring to post myself on the highest point of the fort with an excellent telescope, and view the combat in safety. Far away along the plain, at a great distance from the fort, the hostile parties met (if drawing up at the respectful distance of two or three hundred yards can be called meeting), and the firing began on both sides. The sight was very picturesque. From my post I could see the strong puffs of smoke issuing from either line-the result of the double charges which Indians universally use in battle, under the erroneous impression that they give superior efficacy to the bullets, as well as to strike terror into the hearts of their enemies, while at intervals the braves rushed backwards and forwards on horseback, appearing and disappearing by turns through the clouds of smoke. At last, in rode one of the Minitarées with a scalp in his hand, and was instantly surrounded by a crowd of women and youngsters triumphantly screaming and yelling. This battle, however, did not entirely terminate in favour of the Minitarées, as they had one man slain on their side and carried off by the Sioux horsemen, who dragged him ignominiously along the ground by leathern thongs till they reached their own party, where they scalped him in safety. The skirmish now terminated; the Sioux retired, and the Minitarées returned to their village in triumph, dragging the body of their unfortunate victim along with them. Then commenced a truly disgusting sight; the boys shot arrows into the carcass of their fallen enemy, while their women with knives cut out pieces of the fiesh, which 
they broiled and ate. I turned away chilled with horror, and the whole scene haunted me for hours, and frequently afterwards.

Late in July the American Fur Company's steamer Martha arrived from St. Louis at the Minitarées' post; numbers crowding to see this ever-astonishing phenomenon. The principal men, or chiefs, went foremost, evidently, by their manner and bearing, implying that this was a great display of courage on their parts; the momen and younger portion of the population gradually approaching until the escape of the steam commenced, which, occurring under water, caused a deafening roar, and drove hundreds helter-skelter flying from the bank of the river. Although the steamer annually arrives at this place, it ever affords fresh wonder and astonishment to these simple people; and though an Indian never likes to betray emotion, and always endeavours to conceal any feelings of surprise, the "Maunteshishi" is always more than a match for his stoicism. Catlin mentions that the Mandans, who were the most intelligent and philosophical of all the Upper Missouri Indians, used to say that "this big medicine canoe must have eyes, for how could it always choose the deepest part of the river, and keep in the channel and avoid the snags," an impression which remains in a great measure to this day. I myself heard the observation made in almost the same words; nor do they yet fully understand how its motions can be directed by the man at the helm, or rather by the pilot in his caboose.

A ferw days previous to the termination of its voyage, the steamer was fired into by a war-party of Rhees, one of whose bullets took effect; and after passing through two or three boarded divisions below, split itself on an iron bar: one half buried itsclf in the woodwork, and the other striking one of the deck hands, 
named Smith, in the back of the neck, divided the spine, and killed him on the spot. The poor fellow, I was told, was the father of a large family, depending on him for support. His death was unrevenged; for, although many an American on board grasped his rifle, any further proceedings were stayed by the agents of the Fur Company, who preferred silently submitting to the loss of their follower sooner than run any risk, as they themselves expressed it, "of spoiling the trade."*

\section{CHAPTER XII.}

Leave the Indian country.-A blasted Cannon.-Mr. Mackenzie.Ishmah forages for himself.-The Yellow Fever.-Doctor Farrell. -General Taylor's Address._- "Beauty's" History and Advemtures.-Marriage Feast.-My pretty Hostess. - A Musical Smash. Bruin takes care of Number One.- "Beauty" creates a Sensation.-Bruin rescues the Antelope.-The Balize.

I confess I left the Indians and the Upper Missouri with great regret, and it was with a sigh that I embarked with all my buffalo-robes, grisly bear and wolf-skins, elk-horns, \&c. \&c., and steamed away down for St. Louis. The Martha was a most splendid river boat for her size, furnished with engines of more than ordinary porrer, on account of the rapid current she had to stem towards the far-western part of her course. Boucharville and my faithful followers accompanied me on board, and after many a hearty shake of the hand and mutual good wishes, away dashed and splashed the Martha, rounding the point, and concealing the Mini-

* These two gentlemen were French, not Americans, 
tarée village from my view as the last cheer of my hunting companions fell faintly on my ear.

How I enjoyed the milk, butter, bread, vegetables, pies, and puddings of civilized life, after so many months of animal food, may be imagined. The sudden change disagreed a good deal with me at first ; but those invaluable remedies, brandy and cigars, soon restored me. The following day, as the boat was wooding, the black steward (to whose care I had consigned Ishmah, with an injunction not to lose him on any account) came up to me and said, "Saar, your dog is such a wery mandest dog, that if you don't take care, you will lose him ;" and on my asking for a further explanation of his meaning. "Why, saar, it's now two days I have him tied up in my care, and his bed and fixins is as clean as when you fust chained him, and he's now cryin' from pain: ah! he's a wery maudest dog, wery!" 'The man was perfectly right. I unchained the poor fellow, and allowed him a little exercise on shore. Fortunately he was not afraid of returning to the boat when wooding was over, and henceforth was at perfect liberty, being quite sagacious enough not to lose me.

Before reaching St. Louis, we arrived at the point of junction between the Mississippi and Missouri rivers; the Mississippi's clear stream causing a ridge of backwater distinctly dividing the colours of the two currents. Their united waters from this point into the Gulph of Mexico were falsely named by a mistake of the engineers who first surveyed the country, Mississippi; the nature and tinge of the Missouri being distinctly marked from far above the mouth of the Yellow Stone till it empties itself, after joining the clear blue water of the Mississippi, below New Orleans, into the Gulph of Mexico. On coming in sight of St. Louis, and in order to signalize our arrival, two men of our party, 
together with myself, got hold of an old mortar gun which was on board the Martha, and had been bought cheap of the U.S. artillery, having been condemned by them as unsafe. This we loaded and placed in the bow of the boat, I having primed it with powder from my own horn. On putting a match to the touch-hole, a stunning explosion followed, and the gun instantly disappeared, being utterly shivered to pieces : this was the last ever seen of that piece of ordnance, whose tiagments sank into the waters of the mighty Mississippi, " and left not a wreck behind." Providentially, none of us were seriously hurt: one fellow fell stunned on deck from the fright, the other man's leg was slightly cut, and I received two minute particles of metal scaling in the check, a large piece of the gun flying back and cutting an iron bar right across, close to my face, and having no further effect than to make me then and there for ever renounce meddling with condemned cannons again.

Arrived at St. Louis, I lost not a moment in seeking a ready-made clothes store, there to change my selfmanufactured habiliments for a costume more calculated to escape observation in a civilized community, and, with Ishmah at my heels, was threading my way through the less conspicuous streets until I was unfortunately obliged to cross the fashionable parade of St. Louis ; and had hardly reached the corner opposite, and was congratulating myself on having effected my escape, when I ran against the parasol of a lady, who started on seeing my horrible leather costume all stained and daubed with blood and grease. "Gracious! how d'ye do, Mr. Palliser?" she exclaimed, compelling me to stop and shake hands, and, vastly entertained at my confusion, purposely detained me by a volley of questions, in order to enjoy more leisurely the discomfiture she had caused me by intercepting my headlong flight. 
" Oh! what dreadful creature is that?" she continued, starting back on seeing Ishmah; "you are quite surehe won't tear me to pieces? Well, go away with your wolf; but pray come and dine with us. My husband. will be delighted at your having come back safe, and will ask you a thousand questions about your adventures." (I may here mention that the gentleman alluded to had been long resident in the Indian country, and, among many other distinguishing qualifications, Mr. Mackenzie, of St. Louis, still bears the palm, as having been the best rider and ablest buffalo-hunter of all the whites that ever were on the Upper Missouri.) I soon provided myself at the store with things sufficient for present emergencies, and proceeded to Mr. Mackenzie's, where I enjoyed the best of dinners and wines. Over the latter we sat up together, comparing notes and impressions to a late hour, I frequently reminding him of brilliant hunts, and many other of his achievements and adventures, related to me by Indians and trappers of the country, but which he had for the most part himself forgotten. None can like sportsmen so thoroughly enjoy the luxury of passing the bottle, when they sit together retailing and listening to their mutual adventures; for hunting; in the extended acceptation of the term, is one of those very few occupations, in the pursuit of which sportsmen good and true are never actuated by envy, jealousy, or unworthy emulation.

The Planters' Hotel, where I put up during my stay at St. Louis, was very full, and among the numbers. who dined at the table every day were many choice spirits from the western regions and Rocky Mountains. Some idea may be formed of the number of guests, and of the dishes provided for them, from the fact that the first removal of the iron covers is attended with such a thundering crash as to startle a stranger, and leave him. 
in utter astonishment as to its cause; the only similar effect, I am aware of, being that produced at Exeter Hall, when the turning of the leaf of a little book by each of the audience at the same moment resembles a hailstorm on the roof of the building. Ishmah was so terrified, that he ran right away into the town, followed by his hatless master, who had to leave his dinner for the pursuit, and only brought him back again with considerable difficulty. Here my friend Owen and I met again. It may be supposed we found the fare excellent, especially when our reminiscences carried us back to the period of lean deer-meat and frozen water; and often, as one of us raised the decanter of iced Madeira or cool claret to help the other, did we accompany the action with some such expression as, "What wouldn't you or I have given for such stuff as this on the prairie, eh?" Ishmah, now no longer terrified at the dish-covers, was not content with beholding his master enjoying the good things of this life, but contrived unobserved to creep to the sideboard within reach of the dishes. In one instant his fore-pars were on it, and he had helped himself to a calf's head, with which savoury prize he decamped at racing speed, his bushy tail stretching out, like a fox's brush, behind him; the waiters merely pointing after him and winking to one another, evidently enjoying the joke.

The weather now became very warm, and as I knew it would prove still hotter further south, I left my bisons in the Missouri country, intending to return and transport them early in winter, when the weather should have become cooler, as I did not wish them to incur any danger from the heat during their passage to New Orleans, or the still more fiery ordeal of crossing the Mexican Gulf on their passage to England. Business compelled me to go to New Orleans at once, where I arrived just in time to meet scme old country friends 
previous to their annual migration. New Orleans has the name of being a much more unhealthy place than it really is : numbers fly away at midsummer in order to escape yellow fever. This complaint is also represented as a far more serious evil than is now the case. Formerly physicians did not properly understand its treatment; but now the experienced medical men are so thoroughly up to it, that when taken in time, it is more quickly and easily cured than any other fever, and possesses this great advantage, that when recovered, the patient may consider himself acclimatized, and proof from a recurrence of yellow fever or any other, save the dreaded fever and ague, otherwise called chills and fever, of which I ever had the greatest horror, but alrays luckily escaped. But soon after my arrival in New Orleans, I was returning home one evening, when I felt myself seized with an attack of yellow fever; whereupon I made haste to bed, and sent for my countryman Dr. Farrell. He soon set me to rights again; for, on the third morning, I was perfectly well, and before the end of the week, found myself in much better health than my doctor, who was literally worn out with attendance on twenty-seven yellow-fever patients, every one of whom, however, finally recovered. I was sitting with him after dinner, a few days subsequently, when we received an alarm that one of his patients, in the height of yellow fever delirium, had mounted the rail of a balcony outside his bed-room window in deshabille, imagining himself on horseback, and had, as might naturally be expected, fallen into the street. The poor fellow, on being picked up, looked wistfully in the doctor's face, and said, " $\mathrm{Oh}$ ! doctor, that was a monstrous high horse, for I never suffered so much from a fall from horseback in my life !" I am happy to say, for the gratification of my sympathizing readers, that this poor fellow, although much hurt at 
the time, ultimately recovered yellow fever, bruises, and all. What rendered the scene at the same time ludicrous as well as painful, was Farrell's rage at the nigger nurses, on both of whom he wanted to operate with the cat-o'nine-tails, and turning sternly round to me, told me that he saw nothing to laugh at in such gross neglece of his patients.

A few days afterwards I crossed the Lake Poncha; train to Pass Christian, a beautifully-situated axd favourite summer retreat of the fashionables of $\mathrm{New}$ Orleans. Vigorous and extensive preparations were it. progress for a large ball, which was to be given to General Taylor. Montgomery's hotel was the seene chosen for the festivities - a large building containing a splendid ball-room, where, previous to the commencement of the dancing, an address was presented to the general, to which the old gentleman read his reply. Unfortunately, however, this document had been so badly written for him, that he stuck hard and fast several times in its perusal; but, by holding it up from time to time to the light of a chandelier, and with the help of a few suggestions from by-standers, he finally achieved it. Of course, this very much delighted the young ladies, who evinced much greater pleasure than they would have shown at a more elaborate rhetorical display. Dancing succeeded, quadrilles, polkas, redowas, and waltzes, separated by intervals of delightful walks in the open air through the gardens, which were lighted with coloured lamps strewn among the laurels, so as to form words recounting the victories of the good and gallant old general whose triumphs we were celebrating. The entertainment, on the whole, was most successful, and terminated with a capital supper.

In the month of October I returned again to St. Louis, in order to convey my bisons and other animals down the Mississippi. I had now quite a menagerie to 
take with me ; consisting of one very large old bison cow, one cow rising two years old, and the two calves, one black bear, two Virginian deer, an exquisitely beautiful little forcifer antelope, and Ishmah. Of all these animals, the most remarkable one was my old bison cow, Beauty, whose history, as well as I could gather, was, that she had been some years previously attracted from the prairie by the hay which a distant Mormon farmer, beyond the outskirts of the settlements, was in the habit of providing for his milch cows during the winter, and that, from being accustomed by degrees to the society of the cows, she at length lost all apprehensions of danger from the men who attended on her domestic companions; and, although she at first fled away on their approach, she afterwards became so perfectly tame, as to allow herself to be driven home along with the milch-cows. In the breeding season she used to disappear from the country altogether, but invariably returned, before the severity of winter recommenced, to the society of the farmer's cows, where no one molested her. This animal, being old and very fat, they had sent down to St. Louis, with the intention of selling her to a butcher, rightly judging that purchasers would easily be found curious enough to pay a high price for bison beef, in order themselves to test its so frequently reported excellence. But, most fortunately, I was just in time to avert her fate, and, by paying a higher sum, terminated a bargain pending between the man to whom she was consigned and the butcher in treaty for her, and finally consigned her to Ireland, where she has since become the mother of two splendid calves. She is a magnificent creature, weighing thirteen and a half cwt., and far surpassing in size any specimen that has ever been obtained for a zoological collection, having attained her full growth and strength long before the period of her acquaintance with the dairy cows. The gentleness and intelligence 
of this enormous animal was truly wonderful, rendering her transport very easy. On my embarking her for the first time, she quietly suffered herself to be led along the main-deck of the river-boat, passing fearlessly by the hissing engines on either side to the place prepared for her astern. My other bisons were not so easily managed; but, being then young, we were able to master them. Unfortunately, in recapturing one of my calves, the animal broke its back, an accident which I regretted very much, and the more so, that I had captured him and his companion myself, and was particularly anxious to bring them both safely to England. Herr Zoller, however, a wealthy butcher in St. Louis, happened to have one which he kept as a pet, and which was growing rather too large for the confined place where he was obliged to put her; so, on my wanting to buy her, he, with that frankness for which Germans are so conspicuous, made me a present of her, on my paying the expenses which her transport from the Indian country had cost him; and Madame Zoller (for so I named her) is now in Ireland, in daily expectation of a prosperous accouchement. The bear, antelope, and Ishmah were all on most friendly terms-an object I had taken great pains to effect; and I used frequently to see Bruin and the antelope eating at the same head of cabbage together.

My obliging friend Herr Zoller, a few days before I left, invited me to a German wedding. The bride was the daughter of one of the wealthy members of the corporation of butchers, all of whom, indeed, seemed very well off-a circumstance which Zoller explained to me as resulting from the law in Prussia and the Rhenish provinces, ordaining that no one shall practise the trade of a butcher without paying to the government a sum considerable for people in their rank of life; so that none but young citizens with good prospects are taught, and consequently many of them, when qualified, keep 
their capital and migrate to the United States. The bridal party, and all their guests and friends, assembled at the German Gardens, about two miles from my hotel, in the outskirts of St. Louis. 'The proprietor kept most excellent German wines, and had a very large ball-room attached to his establishment, and a splendid orchestra of brass instruments in his pay. He gave the entertainment, and provided the capital supper, on condition that all except the bridal party should pay for the wine they drank. About nine o'clock in the evening dancing commenced, the orchestra playing Strauss's and Lanner's quadrilles and waltzes to perfection, besides all the best and latest polkas and galops, not excepting the celebrated Railway and Sturm Marsch. Urged by these, I became so exhilarated as to run down and scek the lady of the establishment, who was busy in the lower regions, superintending the culinary operations of her handmaidens. My proposal of dancing the Sturm Marsch galop with her was at first received with utter astonishment ; but after a little persuasion, her pretty features relaxed into a smile; and she began to make excuses as numerous as the dishes she was preparing. Her husband would be angry at the work being neglected; perhaps the maids would want to dance too, if she once began, and so on. A little persuasion, however, soon removed these obstacles; and at last, upon my protesting, in reply to her question, "Are you serious, or are you laughing at me?" that I would quit the premises forthwith, if she did not comply. "Lieber herr Je !" she said, "look at my dress." "Well, take off your apron," I replied. She laughed, and turning to one of the maids, bid her bring water, soap, and towel, "and the cap with the ribbons," adding, as she smoothed her beautiful hair, and looked coquettishly at me, "You know there is no reason for looking uglier than one really is !" At last the cap was adjusted ; but just as 
we reached the ball-room, the galop was drawing to a conclusion. This, however, I had foreseen; and in consequence of a message previously despatched to the orchestra, the moment our hostess and I entered, the Sturm Marsch raged with redonbled fury, and soon bore us off flying before the gale. A glance from her husband, however, caused my Cinderella to dive into the lower regions again, before the termination of the dance, exclaiming, as I caught the last glimpse of her, "Well! perhaps after supper." I continued to wander about, and turned my attention to the bride; but she was "hässlich"-plain, so I consoled myself with supper, and sent a dozen of wine to the orchestra, which I afterwards heard had been presented to them with the compliments of the great English lord from the "Felzen Gebirge." After supper I regained my beautiful hostess, who, in addition to a more becoming change in her dress, had donned a pair of newer shoes, that did not come off every moment in dancing. Shortly after we reappeared, the Hockheimer was finished in the gallery, whence, in gratitude or honour to me, "God save the Queen" rang out its thrilling harmonies from seventeen brass throats. I felt so touched by the compliment, that I think I should have sent another dozen aloft, but for the expostulations of my fair partner, who was apprehensive of its influence on the music. I remained so late, that all the omnibuses had returned to town, except the one destined for the conveyance of the orchestra, with whom I took my place at two in the morning, to return to the planter's house. In conversation with them, I happened to ask if they knew a favourite polka of mine. " $\mathrm{Oh}, \mathrm{ja}$ !" and in an instant all the brass instruments rere blazing away in the confined space of the crowded omnibus. Fortunately, however, before the drum of my ear gave way, the axletree did, and down we came with a jolt that put an end to 
harmony; off rolled one of the wheels, and-" chaqu'un pour soi" - each had to make his way home as well as he could.

Soon afterwards I bid farewell to St. Louis. The steamboat which was to convey my menagerie had two large provision-barges in tow lashed alongside of her, containing Indian corn, wheat, cotton, and hay, freight to New Orleans, in consequence of which she was unable to continue her voyage at night; so allowing this to start before me with all my live lumber on board, I took passage in another, and travelling all night as well as day, stopped at Cairo (otherwise the immortalized "city of Eden" in "Martin Chuzzlewit") on the mouth of the Ohio. Eden really did prove a "jolly" place to me, though not in Mark Tapley's acceptation of the word; for as I arrived there very early in the morning, I immediately sallied out to hunt, rightly calculating that the other boat could not overtake me much before noon on the following day. I had a most successful hunt, and shot two very fine bucks, which I dragged out of the woody swamp to a waggon-track and left there, heaping wood upon the carcases to protect them from vultures, and purposing to send a horse for them on my return. I also laggged a brace of turkeys, which I carried on my back, and reached the hotel (which was a condemned river steamboat) very late in the evening. Next morning an American farmer most kindly volunteered to find and bring home my venison, as I could not risk the loss of my passage by going in quest of it myself. About ten o'clock he returned with the stags in a light cart just as the steamer came up, and in time to put them on board, whence they were stowed in the ice-box, and finally eaten by my friends in New Orleans, who found them excellent, and likewise the turkeys, which were very fat.

One day, after a heavy shower of rain, I was sum- 
moned on deck by the peals of laughter over the dining cabin. On going above to discover the cause of the merriment, I saw that the bear was gone, and his chain broken. The pilot, who had been relieved a few minutes before, now led me forward to inspect his caboose, which was surrounded by the passengers and deck-hands all in fits of laughter. I could not make out the cause of it at first, until one of the bystanders pulled a corner of the blanket of the pilot's bed, when, to my surprise, the jerk was answered by an indolent growl !-my friend Bruin having got drenched by the shower, had broken his chain in disgust, and actually found his way to the pilot's bed, clambered into it, and rolled himself comfortably up in the blankets. The good-humoured pilot was not in the least angry, but, on the contrary, highly amused, replying to my apologies as I kicked out his strange bed-fellow, "Oh! never mind, mister ; why, what's the hindrance to the blankets being dried again?" and "Well, well, now! I'll be $d-d$ if he ain't a knowin' coon." I thought to myself, whether one of my countrymen, or indeed I myself, would have taken the joke in such good part.

On arriving at New Orleans, my first care was to provide an abode for my bisons and other animals, and next a ship in which to transport them. Some weeks, however, elapsed before I succeeded in engaging their passage by the Abbellino, commanded by Captain Crozier, who took the liveliest interest in the success of my project. It was most amusing to witness the consternation of the horses, as well as the astonishment of the people, on seeing the bisons, particularly the large cow, as she passed along the streets from the stables to the river, and then on ship-board; in fact, I found it necessary, in transporting her from place to place, to send some one in advance, to caution any who might have horses in their charge; and this precaution, I am convinced, prevented 
some serious accidents. One old gentleman, who was riding a very fresh young horse, had just barely time to dismount and hold him, by the advice of my outrider, when he commenced trembling and snorting as he winded the cow; and finally, on her nearer approach, broke right away from the gentleman, and rushing wildly through the town, was not retaken without considerable difficulty.

I engaged a carpenter to build me a wooden house, which the captain allowed to be screwed firmly on to the deck of the vessel, affording me every assistance in his power, and the aid of his own ship's carpenter : this house was divided into compartments, and lined with canvass, well stuffed and padded, to prevent any injury to the bisons from their being knocked about, in the event of rough weather. The other animals were very easily stowed away. The bear proved to be the most entertaining member of the whole ship's company; he ate, drank, and played with the sailors, and proved such a source of amusement to them, that the captain, whom I since have had the pleasure of meeting, told me that he would gladly engage always to take a bear with him when he went to sea in future. Bruin was also great friends with the little antelope, and proved on one occasion a most valuable ally. A friend of mine, Mr. Fisher, was leading the latter through the streets to the vessel, while I was following a short distance behind with the bear, when the antelope was attacked by a large mastiff; my friend kept the brute off with. his stick as well as he could, calling loudly to me fo: assistance. I rushed to the rescue instantly, but soon found that the bear not only ran faster than I did, but was determined to tackle the mastiff himself; so, letting go his chain, I cheered him on at the dog, who, finding himself attacked, turned on the bear, and a splendid fight ensued. At first Bruin fought only with his 
porrerful arms, flinging the dog over and over several times, till at last the latter, cheered on by his owner to renew the fight, succeeded in giving the bear a pretty sharp pinch; upon which Bruin, getting furious, threw himself on his antagonist, and hugging him in his arms, endeavoured to tear him with his teeth. I thought it was all up now with the luckless dog, and felt rather sorry for his fate, when I heard his stifled gurgling; fortunately, however, with a last spasmodic struggle prompted by despair, the poor dog extricated himself, and ran away howling.

I embarked on board the vessel with my menagerie, and proceeded down to one of the numerous mouths of the Mlississippi, called the Balize ; intending, as soon as the vessel put to sea, to borrow a boat, and endeavour to obtain some duck-shooting. As we descended, we passed continual sugar-plantations, dotted with the residences of their owners, until we reached chaos again, where trees disappear, and reeds and canes mark the silent waste, - the contemplation of which is in the last degree depressing to the spirits.

The village of the Balize consists of a few wooden houses built on piles, and inhabited by fishermen, and those in charge of the lighthouse there ; and so thorough a swamp is this miserable spot, that the paths to, and in front of the houses, are along planks of wood. At the request of Captain Crozier, the officer in charge of the place lent me a very fine boat, and a negro who had been in the habit of sailing her. Next morning at high water the Abbellino passed the bar of the river, and sailed for Liverpool; while Fisher and I, with our negro boatman, set out on a cruisc after ducks, snipe, and alligators. 


\section{CHAPTER XIII.}

Snipe and Duck-shooting.-Norwegian Sportsman.-A wounded Alligator proves a disagreeable Boating Companion.-Negro torn by an Alligator. - The Falcon.-Chagres. - Storming the Spanish Fort.-Tropical Thunderstorm.-Panamà.-Santa Anna Cathedral.-The Pope inexorable.-Home by English Mail Steamer.

$W_{E}$ enjoyed tolerable sport by getting out of the boat, where the swamp was sufficiently firm to bear us without sinking more than knee-deep. While beating over those places that were free from canes, we shot a few snipes, one or two ducks, and some teal ; and, after a hard day's rowing, and wading nearly up to the middle in water, we arrived at a miserable hut, tenanted by a very poor sickly couple, with a large unhealthy family. The poor people invited us with a welcome to all their miserable little hovel afforded; but as I had brought with me plenty of biscuits, pork, cheese, a box of sardines, coffee, sugar, brandy, and cigars, besides a little money, my poor hosts were not long before they, discovered that "they had entertained angels unawares." The following day we repaired to a flooded swamp, the beat of several men who rere in the habit of shooting wild fowl for the New Orleans market. We found a Norwegian with his canoe very hard at work, with whom I fraternized: he was at first rather disappointed at seeing us, but I soon assured him that we would not spoil his sport. First I bought one or two teal he had killed, and secondly told him, if he would take us to the passes in his canoe, I would in the evening purchase from him whatever we three had bagged in the day. He then proceeded to place us one after the other-as the canoe could only contain two persons at a time-in 
ambush, at two passes over which the water-fowl were constantly in the habit of flying, and ensconced himself in his own retreat; when, by means of an instrument, he imitated the cackling of water-fowl, bringing them over his head; and, on his firing, they frequently flew towards Fisher's or my retreat, affording us fair shots; so that in the evening we mustered a bag of nine ducks, seven teal, and three or four snipes.

Late that night, as we were silently gliding across the mouth of one of the passes of the river by the light of a splendid full moon, and before a gentle breeze, the negro pointed out what he asserted to be an alligator, lying asleep on a large snag in the water. For some time I thought it only a second crooked stem lying against the snag, twisted in some fantastical shape: however, I drew the shot out of a heavy duck-gun that lay in the bow of the boat, and not having a bullet about me, substituted a charge of buck-shot. Seeing that the wind was favourable, I desired the negro to steer close alongside; and we soon passed within eight or ten yards of the brute, on which I gave him a shot in the head, which I thought had done for him. We lost not a moment in securing him; the nigger got out and fastened a rope round over the fore-part, and a hitch round the tail, and after a good haul we three heaved him into the boat, an undertaking that gave us enough to do. We had hardly completed our task, and taken a horn in honour of the event, wheneven while congratulating ourselves on our success in safely stowing him along the bottom of the boat,-up rose his ponderous tail, descending in the following second with a slash that made the knees of the boat shake again.

"By golly, master," said our black boatman, "I wish him nebber had come into this boat ;" and we heartily wished our prize in his more congenial element again, 
as lash after lash of his ponderous tail followed in rapid succession, breaking up the thwarts, which one after another went flying about, either striking us or falling into the water, accompanied by groans from blacky; who grasped his shins with his hands, in sure indication of the utmost nigger uneasiness. I was utterly perplexed,-not daring to fire for fear of swamping the boat, - and unable with my knife to pierce through his tremendous scales. Fortunately, however, our sound little Yankee craft stood the leviathan shocks, and at length the alligator safely expired; when we drew a long breath again, put up our helm, and reached the squatter's hut again before the moon disappeared. Next day we hailed a tug steamer, which picked us up, and took us back to New Orleans.

A few days afterwards my friend Mr. Taylor and I crossed the river from New Orleans to the Algiers side, breakfasted with Mr. Gardère, with whom we afterwards went in two canoes alligator-shooting. We wounded one or two, which we failed in getting : however, I think the principal reason of our want of success was Taylor's comic songs, which he persevered in singing, notwithstanding all our remonstrances.

While sculling among these flooded swamps, we steered through a lovely grove of orange-trees, stretching at each side of the Bayou, along which we were gliding; these contrasted most wonderfully with the dismal rank vegetation in this but partially explored region, and I afterwards learned how the growth of this beautiful orange-grove was to be accounted for. A party, more than twenty years previous to my visit, had been out duck-shooting there, having, among other eatables, brought out a quantity of oranges with them, which they had then and there eaten, and throwing away the skins into a luxuriant deposit, the seedlings had sprouted up; and now a most beautiful orange-grove remains to 
this day to mark the spot. On our ray back to Mr. Gardère's house, and near the cultivated portion of his plantation, he pointed out a single tree on the bank of the Bayou, down which we were paddling, and told me that the tree in question had been the means of saving a man's life. One of his negroes, a few years ago, was asleep near this watercourse after his dinner, when he was awakened by the clenching of the teeth of an alligator across the calf of his leg. The monster, in spite of the most frantic resistance of the negro, was rapidly dragging him down to the water, on his way to which he fortunately passed the tree, which his victim immediately grasped in his arms, and held on by the trunk, until his screams summoned the rest of the negroes to the spot: their arrival fortunately induced the alligator to let go his hold, and rush back into the water again, leaving the man's leg dreadfully lacerated. The man subsequently recovered, but remains lame for life, from the fearful manner in which the muscles of his leg had been lacerated by the alligator. Negroes have often informed me that the flesh of the alligator is very good, and eats like beef; however, I never put its flavour to the test.

The time had now arrived for my departure from New Orleans-a period which I shall ever look back upon with regret. I had been so hospitably received, and had made so many friends, that my farewell round of visits threw me into a fit of the blue devils, from which I did not recover till far on my way towards the Havannah by the American West Indian mail steamer.

We were unable to land at Havannah, owing to a perverse notion the Spanish authorities had taken into their heads, that passengers from New Orleans were contaminated; but I had an excellent view of the harbour. In the evening the Falcon steamer came along- 
side for our Californian friends, and I shifted my traps into her, preferring to alter my route home, and going round by the Isthmus of Darien, to performing quarantine on a. Spanish hulk, surrounded by Spanish sentries, a victim of extortionating victuallers, and the companion probably of sufferers from various malignant fevers.

Our trip to Chagres on board the Falcon was very pleasant indeed ; the passage cost 223 , and our table comprised every delicacy of the season, and ice in the greatest abundance. The captain of the Falcon, Thompson, was the life and soul of the party, and devoted much of his time to his passengers, encouraging gaiety in every way. This steamer was a great deal more comfortable than our English ones, admitting of an immense dining-saloon, at the head of which the shaft of the wheels passed through. On our way into breakfast and dinner, however, we had to stride over it continually, a great source of merriment at the expense of the ladies, as we suggested the very superior advantages of Bloomer costumes in such emergencies; for as it of course constantly revolved, they could not step upon it.

Most of my fellow-passengers were adventurous spirits bound for the Californian mines. Amongst them, however, were some distinguished American officers going out on official appointments; among whom were Mr. King, member of Congress, empowered to treat on the subject of boundary-lines with the Mexican government, Colonel Hawker, and Captain Ringgold, who distinguished himself so highly in the United States South Pacific exploring expedition.

After a most delightful passage of thirteen days, wo came early in the morning of the 2nd of Mry in sight of Chagres. Here I landed, Captain Thompson having very kindly sent me on shore in his own boat; being 
determined to visit Panama, and see some of the mestern coast of the isthmus.

Chagres Bay is a most lovely spot; there for the first time I beheld a tropical climate in its full grandeur, with ever-verdant woods growing actually down to the sea; distorted mangroves, nerr and strange fruits, canes, and palms, in the greatest abundance and luxuriance, as in a scene from a fairy tale. Sugar-cane, which had never been the prey of man's covetousness, grows free and wild to the extravagant height of seventeen feet. while the banana-leaf, shaped like a gigantic ace of spades, expands its length of sixteen feet, and measures five feet across.

A fine old Spanish fort (built, some say, by Pizarro, others by pirates) stands on a splendid bold angle of cliff, itself a strong and very curious old place. The houses of Chagres are built of canes, lofted in the same way, and thatched with leaves: the inhabitants are mostly very poor and miserable. A wonderful conglomeration of races, bred between the white, red, and blacks, has taken place in this peninsula; they are a docile, laborious set, and if only directed by any enterprising leacier, would soon render their country a fertile one, and become themselves a thriving community. It is a great mistake to state, as some travellers have done, that they are a set of lazy, idle rascals, for such is really not the case ; if set to do any kind of work, no matter how laborious, they will go through with it.

I ordered a canoe for Gorgona, almost the head of the navigation of the Chagres river; and while the meri were cooking and eating their dinners, preparing the canoe, Scc., I went with an American acquaintance to visit the fort,- - the easiest ascent to which, even on the land side, was very steep. On arriving near the open gate of the fort, the garrison, which consisted of five 
men, refused us admission unless we paid them, and at the same time barred the wicket. My friend then drew a most awful-looking bowie-knife, while I, applying my shoulder to the wicket, burst it open, when we both quietly marched on, and without noticing the garrison, continued to inspect the different objects which most interested us. The guns of the fort were long thirtytwos, of most costly-looking material, a sort of bellmetal perhaps, but certainly a composition in which silver largely entered. On these beautiful pieces of ordnance the arms of Spain were magnificently emblazoned; also the date when they were cast. I regret, however, that I omitted to make a note of it; but my impression is, that the figures are A.D. 1573. The guns are in a fine state of preservation, though their carriages are in various stages of decomposition, crumbling from age, and most of them are crushed beneath the weight of the supcrincumbent metal. On our departure we found the garrison drawn up in front of the gate by which our exit was to be effected, each armed with his rusty musket without a bayonet. A glance satisfied me that they were, even if loaded, not very likely to go off; so my companion and I halted; handing me his tremendous bowie-knife to flourish, he drew a five-barrelled revolver, while I threatened, in a mixture of bad Italian and worse Latin-which I intended for Spanish-that hostilities would instantly commence on our side if they did not immediately open the wicket-gate, which summons they at last sulkily obeyed.

In the evening, at a little before sunset, I commeneed my ascent of the Chagres river. The wild, tangled tropical vegetation along the banks was indescribably grand, and the air was filled with the discordant screams of macquaws, parrots, and parroquets of all sizes. We 
paddled along by the light of a splendid moon till very late, when we reached a small village; the houses of which, like those of Chagres, were constructed of reeds and thatched with cocoa-leaves. The sound of a drum announced that a fandango was taking place in front of the houses on the bank. I went ashore, preceded by my boatman, who soon escaped, got drunk, and left me in the lurch; so finding I had nothing for it but to submit to circumstances and make the best of it, I joined the dancers, and when the fandango was over, was invited into one of the houses, where I passed the night. One-half of this habitation was lofted inside with strong canes fastened together; and the very primitive substitute for a staircase was a large $\log$ of wood quite in the rough, with one end on the ground and the other leaning against the edge of the loft, and having notches cut in it, by means of which the inmates of the house went up or down-an exercise requiring considerable practice and expertness to accomplish with safety.

I rose before daylight, anxious to perform as much of the remainder of my journey as possible before the noonday heat should overtake us. I had considerable difficulty in finding my two boatmen, but at last got under way, though not before I was obliged to dissipate some of the fumes of the foregoing night's carouse from the senses of the elder of the two by a wholesome stern application of the flat of my paddle ; whereupon he jumped up with the utmost alacrity, rubbed the part affected, took his place in the boat, and paddled away as briskly as ever. The day became so hot at twelve o'clock, that we did not resume our journey until after four, and we had hardly started again, when a violent thunderstorm commenced. I was greatly entertained with the proceedings of my men, who 
intently watched for the first symptoms of rain; and as soon as they saw pretty clear indications of "agua," undressed themselves, stripping off every single article of apparel, and, rolling them up in a piece of oiled cloth with which each was provided, quietly went on paddling in a calm which was truly awful, Nature seeming to collect her energies for the fearful burst which succeeded; even the noisy birds feeling the influence, and hushing their discordant cries. At last the storm broke. The thunder, instead of rolling, broke overhead with a crash like ten thousand gongs-a stunning, maddening sound, utterly unlike the sublime, awe-inspiring roll in our latitudes; the warm rain poured down in massive columns, almost checking my breath, as mouth and nostrils filled at each respiration. And now for the first time in my life I saw a tree struck by lightning, the flash falling on one a short distance off, riving the huge trunk, and sending the splinters flying far and wide from the spot. The storm did not last long, but suddenly, as the change of a panorama, gave way, to a lovely sunset; the little monkeys crept along to the extremities of the branches, to stroke and dry their dripping fur, and parrots and masquaws flew about and screamed as noisily as ever.

Even before we reached Gorgona, the ascent of the Chagres river became very difficult, the stream proving too strong for us to make any further way with our paddles, and we were consequently obliged to punt our way along with the boat-poles. I reached Gorgona early on the following day, whence I took a pony to Panama, where $I$ arrived on the evening of the third day from Chagres. My ride on that day was a very easy one, for although there was no regularly-made road, the track was very clearly defined, and led through 
forests, up and down hills, along valleys, and densely mooded causerrays: so thick was the parasitical and orchidaceous regetation, that to penetrate the roods in any direction but that indicated by the path would have been impossible, without the aid of the very long knife or sword used by the natives to cut through the tangled mass. Every here and there the track was strewn with dying and dead horses, some far advanced in decomposition; while the white bleaching skeletons could be seen dotted all along it in advance from erery rising ground and crest of hill during the journey.

Panamà is a most curious and interesting old Spanish town, and, with the exception perhaps of a small part of New Orleans, utterly different in architecture from any tomn on the Atlantic coast of America. It was late and nearly dark when I arrived; but, eren before reaching the walls, I was hailed by some Americans, inquiring the news from the United States. Their numbers rapidly increased to a large assembly, and I had to rein up my tired horse and answer, I fear but very vaguely, to many anxious inquiries, giving them finally a very spurious account of the state of politics in their country since their absence, in a speech which I made to them from horseback. It seems I had, by travelling so rapidly, anticipated the mail, which did not arrive till the following day.

The next day was Sunday, and I went to visit the cathedral of Santa Anna, one of the oldest European structures in America: its architecture was nothing wonderful; and the only things calculated to attract either interest or curiosity, are the large and beautiful shells with which it is ornamented on the outside. J. went to hear mass there, and was struck with the wonderful rapidity with which the old rescoro got through it, and said as much to an old man with whom 
I had made acquaintance the day before, and who was accompanying me. "Ah," he replied, "he has such beautiful fighting-cocks, and a great match comes off at eleven o'clock, and he wants to be in time, for one of his own cocks is going to fight, and he has backed him heavily."

The great influx of Americans bound for the golddiggings raised the price of everything; I was much interested by the accounts I heard of San Francisco and the Sacramento, which I need hardly transcribe here. The wages were enormous. Mrs. Smith, wife of the commandant of the territory, used to pay $£ 2$ a day wages for her kitchen-maid, and $£ 1,500$ a year for a house in San Francisco. Tradesmen's wages were also most extravagant-a carpenter's, twenty dollars; but those who made the most money were saddlers, by mending bridles, saddles, and pack-saddles. The accounts brought down from San Francisco while I was staying at Panamà fully confirmed all that I had previously heard in the States ; the quantity of gold found was immense, common working-hands in the short space of four months amassing fortunes.

On the following evening, as I was in the balcony of the hotel sitting with some American acquaintances, we heard "a cry break out which soon swelled into a shout" from all the Americans in Panamà, some six or seven hundred; and so headlong was the rush through the crowded streets, that it was some time before we succeeded in discovering its cause ; till, at last, several booming cannon-shots from the sea announced the arrival of one of the great American steamers from New York round the Horn; and the shouts of triumph from the poor fellows that were reckoning on her arrival were quite thrilling. We rowed out to visit her next day; she was a magnificent steamer, and the passengers of all 
ranks and denominations were strarming in her like bees about a hive. I thanked my stars that I was not destined to become one of their number.

The next day I determined to enjoy the novel sensation of a swim in the Pacific Ocean; but before I had been two minutes in the water, I perceived a large black fin appear above the surface, quite close enough for me to recognise it as that of a shark ; and not much relishing his society, I scrambled ashore out of his way as fast as I could.

The natives of Panamà are Spanish both in costume and appearance: the ecclesiastics wear long black gowns and three-cornered hats: they are not very bigoted. I was surprised, on the Sunday evening, when walking in the neighbourhood of one of the churches, to see four very well-dressed priests seated on a large balk of timber in the street, playing cards. They seemed very much interested in their game, and did not notice my approach at first, till one of them, after a little time, perceiving me looking over them, assured me that they were not playing for money. Many of these poor felloris are very peaceable and harmless members of society. They acknowledge the supremacy of Rome, and are sometimes made to feel it. Shortly before my arrival there, they had received a communication from the Pope, conveying a refusal to a petition which had been addressed to his holiness by the clergy of Panamà, for permission to marry, and which stated, among other arguments, that the evils arising from the prohibition of the marriage of priests were much worse than any which could possibly result from its permission. But though this was urged in very strong terms, and signed by nearly all the priests, the license was peremptorily refused.

From Panamà I returned to Chagres viâ Gorgona, 
and had a miserable time of it. My horse dropped dead under me; the heat was excessive, and I had to walk, or rather wade, more than half the distance on foot through deep mud, into which I sometimes sank above my knees; while, to increase my misery, a storm came on, nearly drowning me, and leaving me drenched to the skin, and wretched to the last degree. At last, howrever, I reached my destination, and took boat from Gorgona, descending the river at a rapid rate to Chagres, where I arrived in time to take passage by the English West Indian steamer back to England.

THE END. 





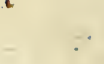


\section{GEORGE ROUTLEDGE \& C().'S NEW PUBLICATIONS,}

SUITABLE FOR SEASIDE AND HOME REAIING.

\section{PRICE TWO SHILLINGS EACH.}

CAPTAIN BLAKL; or, My Life. By MAxwEL.. DEEDS NOT WORDS: a Home Story. By M. Bri,. FEATHERED ARROW. By F. GERSTAECKER. CON CREGAN; (x, The Irish Gil Blas.

PRAIRIE BIRD. By the Hon. Charges A. Murray. LINNY LOCKWOOI), By Mrs. Crow E.

TWO CONVICTS; or, Australian Life. Br T. Gerstaecker.

PRICE ONE SHILLINS: AND SIXPENCE EACH

VIOLET; or, The Danseuse.

FLOOD AND FIELD, BY MAXWELL.

PEREGRINE BUNCE. BY THEODORE HOOK.

MARTIN BECK (the Australian Settler). By. H. IIArris.

CHLLSEA IEWRANS, BI G. R. GHFIG.

ELECTRA. Br the Author of RockiNGHa

FARDAROUGHA THE Miser. By II. Cirletor THE WARD. By Mrs. Trollope.

JAPHET IN SEARCH OF A FATHER. By CAPT. MARKAT. ZINGRA THE GYPSEY. By Mrs MaIllard. MY COUSIN NICHOLAS. By the Author of INgoldsby Legnes. SELF; or, The Narrow Narrow World. By Mrs. Gore.

TIE DUKE. By Mrs. GRiY.

LUCRETIA; or, The Children of the Night. By Burwer Lytron.

\section{PRICE ONE SHILLING EACH.}

THE COMMON OBJECTS OF TIIE SEA-SHORE. By Rev.

J. G. Woop. With many Illustrations, $c$ on $=3$ haUNTED hOUSE. 'By F. Gerstakcker. KING DOBBS. BY JAMES HANNAY. VIVIAN. By Miss EDGEWOITH. ABSENTEE. By Miss Edgeworth.

* * List of 320 Trolumes, gratis, on application.

LONDON : G. ROUTLEDGE \& CO., 2, FARRINGDON STREET. 